\title{
VARIATIONAL METHODS FOR SHAPE MODELLING
}

\author{
Ph.D. Thesis
}

BY

Csaba Molnár
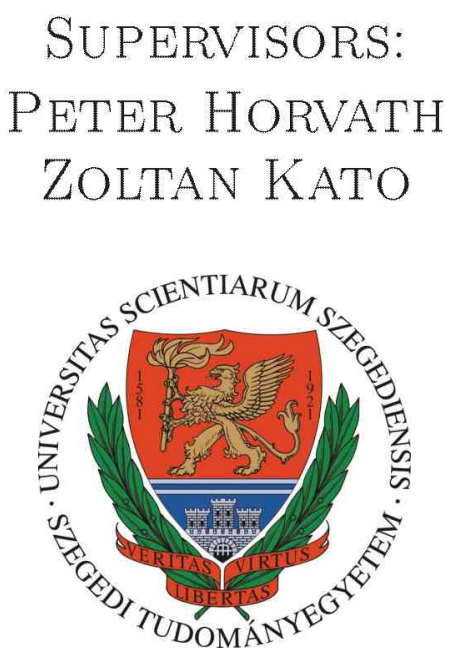

Doctoral School of Computer Science INSTITUTE OF INFORMATICS UNIVERSITY OF SZEGED

Biological Research Centre of Hungarian ACADEMY OF SCIENCES IN SZEGED

\section{SZEGED}

2019 



\section{Dedication}

In memory of my Beloved Ica néni who encouraged me.

I am grateful for her friendship and her great sense of humour. 



\section{Contents}

$\begin{array}{ll}\text { Contents } & 5\end{array}$

$\begin{array}{ll}\text { List of figures } & 9\end{array}$

$\begin{array}{ll}\text { Acknowledgements } & 11\end{array}$

1 Introduction $\quad 13$

1.1 Image processing . . . . . . . . . . . . . . . . . . . . . . . . 14

1.2 Prior knowledge . . . . . . . . . . . . . . . . . . . . 16

1.3 Formulation . . . . . . . . . . . . . . . . . . . . . 17

1.4 Shape modelling. . . . . . . . . . . . . . . . . . . . . . . . . . . 18

1.5 Object splitting . . . . . . . . . . . . . . . . . 22

2 Multi-layered 'gas of near-circles' models 25

2.1 Higher-order active contour model . . . . . . . . . . . . . . . . . 26

2.2 'Gas of near-circles' active contour model . . . . . . . . . . . . . . 27

2.3 'Gas of near-circles' phase field model . . . . . . . . . . . . . . . . 28

2.4 Multi-layered 'gas of near-circles' phase field model . . . . . . . . . . . 29

2.4.1 Dealing with overlapping: geometric model . . . . . . . . . . 31

2.4.2 Functional derivative of the energy . . . . . . . . . . . . . 33

2.5 Image data model . . . . . . . . . . . . . . . . . . . . . 34

2.6 Verification .......................... 34

2.6 .1 Separation ability . . . . . . . . . . . . . . . . 34

2.6.2 Tuning data parameters .................. 34

2.6.3 Implementation issues . . . . . . . . . . . . 36

3 Additive data model for fluorescent microscopy 39

3.1 Overlapping objects in imaging . . . . . . . . . . . . . . . . . . 40

3.2 Data model for overlapping objects/cells . . . . . . . . . . . . 42

3.3 Verification .......................... 43

3.3 .1 Evaluation and metrics ............... . . 43

3.3.2 Dependence on initialization . . . . . . . . . . . . . . . 44

3.3 .3 Object size selectivity . . . . . . . . . . . . . . 44

3.3 .4 Noise sensitivity . . . . . . . . . . . . . . . . . . . . . 45

3.3 .5 Elongation. . . . . . . . . . . . . . . . 45 
3.3 .6 Degree of overlap . . . . . . . . . . . . . . . . . . 46

3.3.7 Results on semi-real data. . . . . . . . . . . . . . . . 46

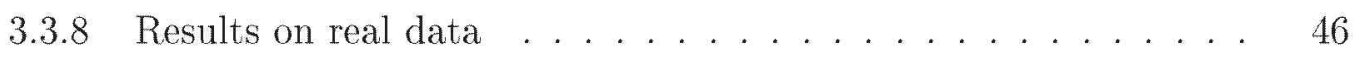

3.3 .9 Performance . . . . . . . . . . . . . . 47

4 Selective active contours $\quad \mathbf{5 3}$

4.1 Selective active contours . . . . . . . . . . . . . . 54

4.1 Notations . . . . . . . . . . . . . . . . . . . 54

4.1 .2 Size priors . . . . . . . . . . . . . . . . . 54

4.1 .3 Shape priors . . . . . . . . . . . . . . . . 55

4.1.4 Smoothness terms . . . . . . . . . . . . . . . . . . . 57

4.1 .5 Composite functional . . . . . . . . . . . . . 58

4.1.6 Energy normalization: dimensionless quantities . . . . . . . 58

4.1.7 Region based local data term . . . . . . . . . . . . 59

4.1.8 Euler-Lagrange equations of selective contours . . . . . . . . 62

4.1 .9 Solving the Euler-Lagrange equation . . . . . . . . . . . . . . 64

4.1 .10 Verification . . . . . . . . . . . . . . . 65

4.2 Multi-layered selective active contours . . . . . . . . . . 66

4.2 .1 Experiments . . . . . . . . . . . . . . . . 68

4.2 .2 Computational complexity . . . . . . . . . . 71

$\begin{array}{lll}5 & \text { Object splitting with active contours } & \mathbf{7 3}\end{array}$

5.1 'Cutting arms' splitting model . . . . . . . . . . . . . . 74

5.1 .1 The splitting functional ................ 74

5.1 .2 Roles of the functions in splitting functional . . . . . . . . . 75

5.1 .3 Optimizing by gradient descent . . . . . . . . . . . 76

5.1 .4 Verification .......................... 78

5.1.5 Computational efficiency and implementation details . . . . . 79

6 Applications $\quad 83$

6.1 High-throughput screening . . . . . . . . . . . . . . . . . . 83

6.2 Single cell isolation . . . . . . . . . . . . . . . . . . 88

$\begin{array}{lll}7 & \text { Conclusions } & 93\end{array}$

$\begin{array}{ll}\text { Magyar nyelvû összefoglaló } & 99\end{array}$

$\begin{array}{ll}\text { Appendix A } & 103\end{array}$

Functional derivative of overlap penalty term . . . . . . . . . . . 103

Functional derivative of image data term . . . . . . . . . . . . . . . . . . 104

$\begin{array}{lr}\text { Appendix B } & 107\end{array}$

Euler-Lagrange equations for the arbitrary function of the curvature . . . . 107

Euler-Lagrange equation for the second central moment . . . . . . . . . . . 108

Euler-Lagrange equation for geometric local region . . . . . . . . . . . . 109 
Specialization for image segmentation . . . . . . . . . . . . . . 111

Calculating the derivatives . . . . . . . . . . . . . . . 111

The pointwise specialization of the local region equation . . . . . . 113

$\begin{array}{ll}\text { Appendix C } & 117\end{array}$

Functional derivative of splitting functional . . . . . . . . . . . . . 117

Euler-Lagrange equations . . . . . . . . . . . . . . . . . . 117

$\begin{array}{ll}\text { Bibliography } & 121\end{array}$ 



\section{List of Figures}

1.1 The power of prior knowledge . . . . . . . . . . . .

2.1 Interaction of boundary points by the quadratic term of higher-order active contours ........................ 27

2.2 Curve evolution using different HOAC parameter sets . . . . . . . . . 28

2.3 Contour energy of 2 circles in distance of increasing values . . . . . . 30

2.4 Evolution of the phase field GOC model of 2 circles . . . . . . . . . . 31

2.5 Multi-layered 'gas of circles' (MLGOC) phase field model . . . . . . . . 32

2.6 Typical configurations of the prior model . . . . . . . . . . . . . 33

2.7 Separation ability of the model f . . . . . . . . . . . . 35

2.8 Results on synthetic images using neutral initialization . . . . . . . 35

3.1 Examples of point spread function and image forming . . . . . . . . . 39

3.2 Comparison of classical and multi-layered methods . . . . . . . . . . . 41

3.3 Illustration of the proposed data model and behaviour of the geometric model . . . . . . . . . . . . . . . . . . 4 4 4 43

3.4 Synthetic results with different initialization methods . . . . . . . 45

3.5 Synthetic results to test the robustness of the model to noise . . . . . . 48

3.6 Robustness of the proposed method against elongation of circular objects 49

3.7 Separation ability of the proposed method . . . . . . . . . . 50

3.8 Segmentation results on SIMCEP data set . . . . . . . . . . . 51

3.9 Segmentation results on real fluorescent microscopy images . . . . . . . 52

4.1 Contour evolution with different geometric priors . . . . . . . . 56

4.2 States of contour evolution . . . . . . . . . . . . . . 57

4.3 The local coordinate system for region based data model . . . . . . . 61

4.4 Comparison of isotropic and anisotropic local region data terms . . . . 61

4.5 Results of the selective segmentation framework . . . . . . . . . 66

4.6 Comparison of selective segmentation framework to existing shape models 67

4.7 Noise test results . . . . . . . . . . . . . . . . . . . 67

4.8 Illustration of the multi-layered data model . . . . . . . . . . . . 68

4.9 Evolution of multi-layered selective contours . . . . . . . . . . . . . 69

4.10 Segmentation results with multi-layered selective active contours . . . . 70

4.11 Segmentation results with multi-layered selective active contours . . . 70 
4.12 Segmentation results with multi-layered selective active contours on real microscopy images . . . . . . . . . . . . . . . . . 70

5.1 Illustration of the object cutting method . . . . . . . . . 75

5.2 Functions of the alignment (left) and the curvature (right) functions . . 76

5.3 Behaviour of the geometric splitting model on different initial shapes . 78

5.4 Results on simulated data . . . . . . . . . . . . . . . . 79

5.5 Results on real microscopy image data . . . . . . . . . . 80

6.1 Data extraction from light microscope images of cells having a particular radius ............................ 84

6.2 Segmentation of lipid droplets . . . . . . . . . . . . . 85

6.3 CAMI (Computer Assisted Microscopy Isolation) results: segmentation and classification . . . . . . . . . . . . . . . . . . . . . . 89

6.4 Cell view of CAMIO database . . . . . . . . . . . . . . . . . 91

7.1 Connections between used and developed models . . . . . . . . . 96 


\title{
Acknowledgements
}

\author{
"Each of you should use \\ whatever gift you have received \\ to serve others, \\ as faithful stewards of God's grace \\ in its various forms." \\ 1 Peter $4: 10$
}

I would like to address the first of my acknowledgement to my supervisors, Zoltan Kató and Péter Horváth. Zoltán introduced the world of research and showed the power of high-level image processing to me. Péter showed me the modern bioimage processing. He taught me how to utilize the theoretical results in real life applications effectively to help researchers from other fields of science, which should be the main aim of this work. He was always supportive supervisor and a good friend for me. I am grateful to Ian H. Jermyn, who showed me advanced mathematical tools and supervised my first trials with patience and humility.

I am very grateful to my colleagues from the university, who helped me a lot in the beginning both in research and teaching. I am thankful to all people in BIOMAG team, who were an inclusive group from the beginning and who we could have a great time together with. Special thanks to Józsi who revealed me the beauty and deep levels of variational methods. A sincere thank you to Dóra Bokor for her proofreading.

Many thanks to my friends who encouraged me so much.

Thank you to my family, my parents Mária and Balázs, my brother Balázs, and Andi's parents Ilona and László, for always being there and supporting me.

I am grateful to my beloved Andi for her encouragement and patience along the long journey. She was by my side even in the most disappointing situations as well as in my successful moments.

Thank God for everything always! 



\section{Chapter 1}

\section{Introduction}

Recent advances in engineering, technology and automation have created the required background for high-throughput research. It may incorporate techniques from different fields to permit rapid, highly parallel, large-scale experiments under a wide range of conditions. This high-throughput concept produces a tremendous amount of data to analyse. Of course, the groundbreaking development of the architecture and computing capacity of computers is essential for processing this volume of data, and therefore advancements in information technology play a crucial role in this new research approach. In many cases the data to be processed are image-like data. For example, modern biological research increasingly relies on images as the primary source of information [1]. New technologies in microscopy allow us to visualize and investigate life at the cellular and molecular levels. To explore meaningful information from these complicated and heterogeneous image data, it is necessary to apply advanced methods of computer vision on these data sets.

The fundamental aim of computer vision is to extract high-level information from the sensed and digitized world by computers in order to promote the automation of accomplishing various tasks. Computer vision includes acquisition, processing and analysis of data derived from real world entities. The ways in which real life objects are transformed into digital images, i.e. the so-called 'image acquisition' process, may vary according to the type of the electromagnetic signal used for imaging the objects, as well as the optical system that collects this signal and the sensors that are capable to measure the energy of the signal. The nature of the signal is determined by the frequency of the electromagnetic wave it was created by. The electromagnetic waves, and thus the signals, cover the whole electromagnetic spectrum, including radio frequency waves (e.g. magnetic resonance imaging), microwaves, infrared light, visible light, ultraviolet light (e.g. telescopes), X-rays (e.g. computer tomography) or gamma rays (e.g. nuclear medicine). The way and the level of processing the acquired digital images are determined by the manner of the application. Computer vision is already used in various fields of life including but not limited to, agriculture, manufacturing, surveillance, navigation, robotics, transport or medical sciences. Therefore, it is no exaggeration to say that the possible applications of computer vision are countless.

The main aim of this research was to develop algorithms that offer solutions to 
unresolved problems of image processing, which is a key step in most computer vision pipelines. The term 'image segmentation' generally refers to the process in which we assign labels to each pixel of a digital image such that pixels with the same label belong to the same real life objects. In other terms, one can define the segmentation in another way: the goal of segmentation is to locate objects or their boundaries within the image. A natural approach of executing a challenging segmentation task is to represent these boundaries with a series of $2 \mathrm{D}$ points in the image domain. A large family of image segmentation algorithms, the so-called active contour models, were invented based on the above approach. Our research focused on the development of variational models for object segmentation in spatially dense scenarios, which models are based on the foundations of active contour models.

First, we give an introduction to image processing and its application in microscopy imaging. In Section 1.2 we present the importance of prior knowledge, and we define a probabilistic framework that assists us to define the segmentation problem and the solution process. We give a brief overview of the evolution of shape modelling methods in Section 1.3. At the end of the 'Introduction' section we describe the most widely used methods for object splitting.

\subsection{Image processing}

As it was mentioned above, in a computer vision application image acquisition is followed by the extraction of information and the analysis of available image data. Image processing is a general term for the computer algorithms that supports this analysis process. The input of image processing, of course, may be an image or a series of images (e.g. a video). Processing itself may include any signal processing operations. The output of image processing may be an image or a set of characteristics, also called features, related to the image. The algorithms involved in the processing procedure might be highly variable depending on the specification of the task. They can be utilized for image (quality) enhancement (e.g. noise removal, smoothing, contrast enhancement), image registration and/or fusion (e.g. medical image analysis, robotics, computer aided surgery), object detection (e.g. surveillance, microscopy), image compression, motion detection etc.

In most biological applications, image segmentation is often regarded as a cornerstone, and also the most challenging step of the analysis pipeline $[2,3]$. Since cellular morphology is an important phenotypic feature, indicative of the physiological state of cell, and is often required for subsequent processing, cell segmentation methods have received increasing attention in recent years [4]. The accuracy of human processing of these biological images highly depends on the expertise of the expert executing the task. Furthermore, the enormous amount of these data to be analysed makes humanexecuted segmentation impossible. For these reasons, the development of automatic cell segmentation methods is still an unmet need and a priority issue in bioimage analysis.

However, automation of cell segmentation is highly challenging. The wide variety of imaging techniques and the extent of heterogeneity of biological systems require almost 
as many solutions for segmentation as the number of applications are. There is no general model to describe the constituents of these systems. The structures of these biological samples are also difficult to describe mathematically in many cases.

The current research focuses on the development of sophisticated algorithms for object extraction (i.e. object segmentation). Since the segmentation of objects within the images is one of the early steps in most computer vision pipelines, usually the only preceding step is image enhancement (when possible), and the subsequent analysis largely depends on the output of the segmentation process. Therefore, the development of segmentation algorithms that ensure more accurate object boundaries is essential for a sophisticated analysis that yields as much information on the image objects as possible.

To properly characterize the image segmentation problem, let us define the concepts first. A digital image is a discrete two-dimensional function ${ }^{1}$. The value of the function at each point of its domain is a quantized light intensity value measured of a real life object. The natural representation of such a function is a two-dimensional array, and the electromagneticments of it are called the pixels. Here we denote the image domain by $\Omega=\{(x, y), 1 \leq x \leq W, 1 \leq y \leq H\}$, where $W$ and $H$ are the width and height of the digital image. The image function here is $I: \Omega \rightarrow \mathbb{R}$.

The classical definition of image segmentation is a process that provides a partitioning ${ }^{2}$ of the image domain. Formally, it means that the output of the segmentation process is a set of regions $\left\{R_{i}\right\}$ if the following conditions are true for them with a given uniformity predicate $P$ defined on groups of connected pixels:

i) $R_{i} \subset \Omega$ for all $i$;

ii) $R_{i} \cap R_{j}=\emptyset$ for $i \neq j$ (no regions intersect);

iii) $\cup_{i} R_{i}=\Omega$ (the regions cover the whole image);

iv) $P\left(R_{i}\right)=$ True for all $i$ (each region is homogeneous);

v) $P\left(R_{i} \cup R_{j}\right)=$ False for $i \neq j$ (the regions are maximal);

where $R_{i}$ is a set of pixels that corresponds to the $i^{\text {th }}$ object $^{3}$.

Even in the simplest case, when the goal is to differentiate the background from the regions of interest (i.e. to separate only two regions within the image), the above defined problem has $2^{(H \times W)}$ possible solutions that satisfy these conditions. This simple example highlights one aspect of the importance of the assumptions about the requested objects.

\footnotetext{
${ }^{1}$ Multi-channel images or image series can be easily derived to a set of 'single-channel' 2D images.

${ }^{2}$ The empty set is allowed to be a subset here.

${ }^{3}$ For simplicity the background is usually considered as an object.
} 


\subsection{Prior knowledge}

Employing assumptions about the objects of interest is required not only for the computers to 'see', but also for the human investigator. With no extra information on what to detect, it is impossible, even for the human eye, to recognize the objects of interest, as demonstrated by Fig. 1.1. These assumptions about the structure of the image are referred to as prior knowledge in the probability theory. We denote this prior knowledge with $K$.

(a)

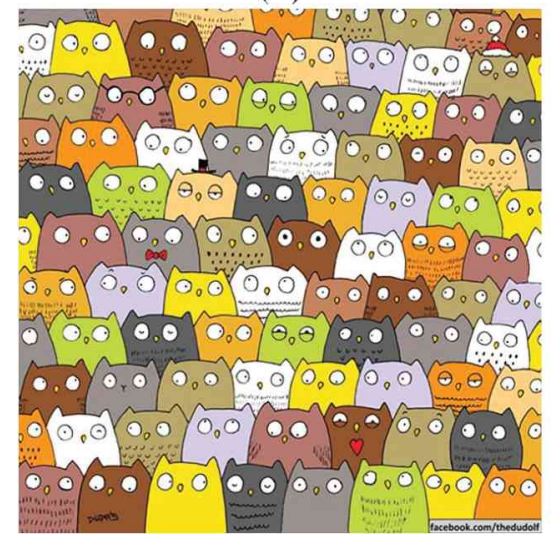

(b)

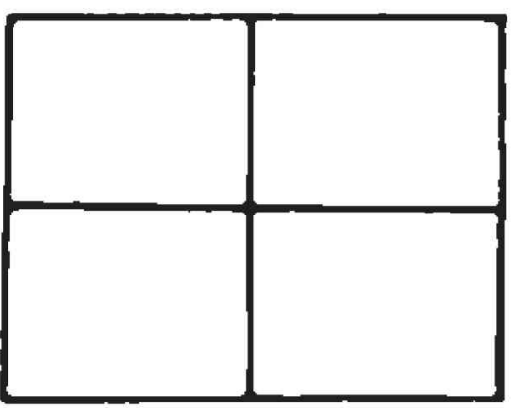

Figure 1.1: The power of prior knowledge. (a) What can you see in this image amongst the owls? A cat is hiding somewhere. (b) Is it a window or a present box?

Even the simplest segmentation methods include prior knowledge. This can be a certain intensity level for thresholding segmentation $[5,6]$. Other methods are based on the assumption that different regions can be characterized by a specific pattern, so-called texture, which gives information about the spatial arrangement of intensities inside the regions. Edges, i.e. sharp intensity changes in the image, are also widely used features in segmentation algorithms $[5,6]$. They both may indicate borders between neighbouring objects or may be used as texture descriptors. A general assumption about the pixels belonging to the same object is that neighbouring pixels of corresponding regions are similar. Region growing methods are based on this local similarity of pixels [7]. Similar smoothness is observable for the edges in real scenes.

The above-mentioned methods may not use information from the neighbouring pixels when they assign a label to a given pixel. Even those which do use are restricted to only a small neighbourhood. Therefore, these methods tend to be highly sensitive to the model parameters or the noise in the image. Obscured objects or the high density of them may also bias false segmentation results via the above methods. A higher level of prior knowledge allows us to solve the higher level of difficulty of scenarios. For the majority of applications we have prior knowledge about the objects' shape. The smoothness of edges in an image can be considered as a very simple type of shape information. Markov random field based methods include this information, in addition 
to encoding some kind of homogeneity within the regions $[8,9,10]$.

Here we should note that different approaches exist for the segmentation of an image. One way includes labelling the image pixel by pixel, which finally gives the expected regions. Thresholding, histogram based methods, region growing methods, edge detection methods and the classical Markov random field segmentation methods are examples of this labelling approach. The other way, which is in the focus of the current research, is based on searching for the boundaries of the objects. These methods represent a region $R \subset \Omega$ in an image by its boundary $\partial R$. In this representation one can imagine a boundary as a closed curve which splits the image space into an inner and an outer part, i.e. the segmented region and the background, respectively.

\subsection{Formulation}

To utilize computers in discovering the world around us we have to translate the above mentioned tasks and prior knowledge into a language that computer algorithms can process. From the huge number of mathematical tools available for modelling we present a probabilistic way to formalize our terms. We can assign different probabilities to each solution, which are defined according to the corresponding prior knowledge. The defined probability distribution allows us to search in the huge solution space of the segmentation task in a smart way.

We denote the space of regions by $\mathcal{R}$, the space of images by $\mathcal{I}$, and the space of a priori knowledge by $\mathcal{K}$. Using Bayes' theorem we can infer $R \in \mathcal{R}$, as possible segmentation, from a given $I \in \mathcal{I}$ and $K$ as follows:

$$
P(R \mid I, K)=\frac{P(I \mid R, K) P(R)}{P(I \mid K)} .
$$

The task is to find one $R$ from $\mathcal{R}$, according to some defined criteria (usually the most probable $R$ for a given $I$ and $K$ ). In case of image segmentation these criteria can be given by a cost function defined on $\mathcal{R} \times \mathcal{R}$ and we will denote it by $L . L(\hat{R}, R)$ gives a cost measure, assuming the ground truth segmentation is $\hat{R}$ when it is in fact $R$. Different uses of the available $I, K$, and $R$ may involve different cost functions. In general we want to find the $\hat{R}$ that minimizes the value:

$$
<L(\hat{R})>=\int d R L(\hat{R}, R) P(R \mid I, K) .
$$

Apart from some special cases, in general the delta function is the only obvious loss function, $L(\hat{R}, R)=-\delta(\hat{R}, R)$. Substituting this function into equation 1.2, gives $<L(\hat{R})>=\int d R-\delta(\hat{R}, R) P(R \mid I, K)=-P(\hat{R} \mid I, K)$. Consequently, the region minimizing the mean loss is given by:

$$
\hat{R}=\arg \max _{R \in \mathcal{R}} P(R \mid I, K),
$$

which is known as the maximum a posteriori (MAP) estimate. It can be re-expressed in a useful way by minimizing the negative logarithm of the probability rather than 
maximizing probability. The negative logarithm of probability is known as the energy by analogy with statistical physics, and its use considerably simplifies the notation involved. For the rest of this section we focus on this expression.

Notice that we look for the region $\hat{R}$ that maximizes the probability defined in equation 1.1 for a given image $I$ and prior knowledge $K$, therefore $P(I \mid K)$ in the denominator is constant. We can rewrite the probabilities in the nominator as:

$$
\begin{aligned}
P(I \mid R, K) & =\frac{1}{Z_{i}(R, K)} e^{-E_{i}(I, R, K)} \quad \text { and } \\
P(R \mid K) & =\frac{1}{Z_{P}(K)} e^{-E_{p}(R, K)},
\end{aligned}
$$

where $E_{i}$ and $E_{p}$ are the image and prior energies, respectively, and $Z_{i}$ and $Z_{P}$ are normalizing functions. Notice that $Z_{P}$ has no dependency on the region $\hat{R}$. Now we can determine now the optimal region by maximizing the probability:

$$
R^{*}=\arg \max _{R \in \mathcal{R}} \frac{e^{-E_{i}(I, R, K)}}{Z_{i}(R, K)} e^{-E_{p}(R, K)}
$$

Finally, as we have discussed above, rather than maximizing this probability we can minimize its negative logarithm, and so we define a very important approach in image segmentation, the so-called energy minimization methods:

$$
R^{*}=\underbrace{E_{i}(I, R, K)}_{\text {image energy }}+\underbrace{\ln \left(Z_{i}(R, K)\right)+E_{p}(R, K)}_{\text {prior energy }} .
$$

\subsection{Shape modelling}

Classical segmentation methods are not robust against high noise, a cluttered background or occlusions, and they strongly depend on the model parameters. Therefore, the idea of incorporating some prior knowledge about the shape of the region has become a general approach to restrict the solution space to a smaller subset of feasible solutions of the segmentation. A generic assumption is the existence of spatial coherence in the image scene, and therefore the early shape prior enforcing this via some kind of homogeneity and contour smoothness [8, 9, 11, 12, 13, 14, 15]. These priors have been incorporated into several different models, such as the Markov random fields, line processes and active contour models. These methods have been proved to be very efficient in dealing with noisy images. However, they cannot deal with a 'higher level of difficulty' in segmentation, such as the high spatial density of the objects. In these configurations the objects can overlap, causing missing information about the ones behind. Even when no covering occurs, but objects with a similar surface (intensity or texture) are located in close proximity within the image, they are indistinguishable which hinders proper image analysis. Therefore, information about the shape of present objects is necessary for proper boundary extraction. In the next sections we list a few results and approaches for shape modelling successfully applied in image processing. 


\section{Template based methods}

One approach to find objects of a given shape may be called the template based approach. It is based on a predefined reference or template shape or a set of shapes for each object class that may occur in the image. In this case, the segmentation task can be considered as an extended template matching problem. When only one reference shape is used, it can be considered as a 'mean shape', as a representative of the objects to segment. The process through which the object of interest is found within the image, involves trying to fit this reference shape to image data by searching for the optimal set of allowed transformations of the template shape. These allowed transformations are usually 'global' transformations such as translation, rotation or other affine transformations, but do not allow 'local', small changes over the object boundary.

Various different solutions are available within the template based approach. Hough transform can be used to find shapes within the images by transforming the feature points (e.g. edges) of the image into a space of parameters that describes the shape. For example, the chosen shapes can be straight lines or circles, but the complexity of the shapes (i.e. the number of required parameters to describe) increases the dimension of the parameter space $[16,17]$. Marked point processes were successfully used to model an unknown number of dises, ellipses or even rectangles [18, 19]. An alternative model for circles and ellipses was proposed by Thevenaz and Unser [20], Thevenaz et al. [21].

However, the mentioned template based methods suffer from several limitations. First, these methods are inefficient when the number of objects is unknown or when objects interact. Each object requires separate representation and computation. Each pair of interacting objects also requires extra computation. Second, the accuracy of object boundaries extracted by these methods is limited to the number of model template shapes and the allowed transformations, and thus slight distortions along the object boundaries cannot be detected.

\section{Active contours and long-range interactions}

Variational methods are widely used in computer vision applications. These methods are designed to find extrema of functionals, where the functionals are the formulation of prior knowledge about a certain task. Here we give a brief overview of two very important families within this variational approach, namely the Mumford-Shah functional [15] and the active contour models [14].

The goal of the Mumford-Shah model is to divide the image into distinct homogeneous regions. To encode this criterion they introduced a functional and its minimization in $[15,22]$. The functional is defined as:

$$
E_{M S}=\lambda^{2} \int_{\Omega} d x(I-u)^{2}+\int_{\Omega \backslash \gamma} d x|\nabla u|^{2}+\mu|\gamma|
$$

where $\Omega \subset \mathbb{R}^{2}$ and $I$ is the original image defined on $\Omega, u$ is the piecewise smooth approximation of the image, $\gamma$ is the boundary between the regions and $|\gamma|$ is its length. 
$\lambda$ and $\mu$ are positive weights of the functional to control the contribution of the corresponding terms. The first term considers that the smoothed image should be close to the original image, the second enforces smoothness, and the third one minimizes contour length. The minimization of the functional is not easy, as explained by Vese and Chan [23] and Aubert and Kornprobst [24]. Many authors have proposed to approximate the functional by a sequence of regular functionals $[25,26,27]$. The numerical approximation is usually based on the Euler-Lagrange equations.

Active contours Active contour models can obtain closed object boundaries as segmentation results. They were first introduced by Kass et al. [14]. In this approach the representation of the boundary of the object of interest is a chain of points over the image space. The points of this chain, or the curve, are forced to move during the optimization process driven by internal and external forces. The original model is able to capture sharp image intensity variations by deforming, and owing to this behaviour it is called a snake model. The energy function is defined as:

$$
E_{A C}=\alpha \int_{0}^{1} d s|\dot{\gamma}(s)|^{2}+\beta \int_{0}^{1} d s|\ddot{\gamma}(s)|^{2}+E_{i}\left(\gamma, u_{0}\right)
$$

where $\gamma(s)$ is a parametrization of the contour $s \in[0,1]$, and $\alpha$ and $\beta$ are weighting parameters that control the snake's tension and rigidity, which in total make the internal energy coming from the curve itself. The external energy $E_{i}\left(\gamma, u_{0}\right)$ is derived from the image so that it takes on smaller values at the features of interest. $E_{A C}$ is a non-convex function, possibly with many local minima, and one of them can be reached by solving an Euler-Lagrange equation [14].

One of the main directions along which the active contour idea had been further developed, was introduced by Caselles et al. [28], and is called geometric active contours. In Caselles et al. [12] the authors proposed the geodesic active contours, a new curve parametrization invariant energy function based on the model in equation 1.4:

$$
E_{G A C}(\gamma)=\int_{0}^{1} d p f\left(\left|\nabla u_{0}(\gamma(p))\right|\right)|\gamma|=\int_{0}^{|\gamma|} d s f\left(\left|\nabla u_{0}(\gamma(s))\right|\right)
$$

where the function $f$ is the edge function similar to the $E_{i}$ in equation 1.4. Caselles et al. also proved that the curve, which minimizes this energy is a geodesic in a Riemannian space. Cohen [13] introduced a new constant artificial force term into the geodesic active contour energy called, the balloon force. The advantages of this model are the possibility of detecting non-convex objects, and faster convergence to the steady-state solution. Geodesic active contours were extended to more than two dimensions in [29] and $[30]$.

Variational methods are highly sensitive to initialization. To decrease or vanish the determinant effect of the initial configuration of active contours, several hybrid solutions were developed. The Markov Chain Monte Carlo approach is used to find the minimum energy of active contour models in a nondeterministic way [31]. The active contour models embedded to a marked point process framework have made it possible 
to achieve 'bigger' steps during the optimization such as birth and death, i.e. creation or deletion, of individual curves in one iteration [32].

Level sets A fast numerical algorithm has been proposed for active contours but in the case of closed curves it does not allow changes of topology, since the final curve has the same topology as the initial one. To overcome the limitation of the changes of topology, Osher and Fedkiw [33] proposed the level set method, where the curve $\gamma$ is implicitly represented by a higher dimensional function (see also in [34, 35]).

The evolution governs the motion by the curvature. Let the level set surface be denoted by $\phi(t, x), t \in[0, \infty), x \in \mathbb{R}^{2}$, where $x$ parameterizes the level set surface and $t$ parameterizes the evolution. The main idea of the level set method is to implicitly represent an interface $\gamma$ in $\mathbb{R}^{n}$ as a level set of a function $\phi: \gamma=\{x \mid \phi(x)=z\}$, where $z$ is a constant threshold level. For details and numerical implementation, see [27, 34], and [35].

The level set method has been used in numerous applications from physics to image processing, such as fluid dynamics, control, ray tracing, image restoration, image segmentation, etc. $[35,36]$. The general evolution equation for the problem of curve evolution is given by the partial differential equation (PDE):

$$
\left\{\begin{array}{l}
\frac{\partial \phi}{\partial t}=|\nabla \phi| \operatorname{div}\left(\frac{\nabla \phi}{|\nabla \phi|}\right) \\
\phi(0, x)=\phi_{0}(x)
\end{array} .\right.
$$

The level set framework has the advantage over the classical active contours that the complexity of the model does not increase by the number of segmented objects during optimization.

Phase fields Phase field model is a mathematical model for solving interfacial problems. It is well known in physics and have been used to model solidification processes [37]. In image processing applications, it can be utilized as special level set modelling technique. While keeping the benefits of classic level set representation (e.g. easy handling of topological changes of contours), the phase field models have several extra advantages. No special initial configuration is needed for the optimization process; as well as the phase field energy provides a neutral initialization for gradient descent. The implementation of phase field models is simpler than the classical active contours (CAC) or their level set representations; no reinitialization or regularization steps are needed, and thus the optimization process is faster.

Higher-order active contours Higher-order active contour (HOAC) models [38] provide an alternative approach to express shape information. HOAC models can describe shape knowledge without templates, using long-range dependencies between region boundary points, and are intrinsically invariant. The long-range interaction is expressed by a multiple integral over the boundary contour. In the simplest case of a HOAC model, the contour energy is composed of area and perimeter minimizer terms, 
and extended by a double integral over the boundary points. This quadratic term competes with the minimizer terms resulting in various preferred shapes, such as network like structures [38]. To extract tree crowns in aerial images, Horvath et al. [39] have proposed a special parametrization of the HOAC model, the 'gas of near-circles' (GOC) model that prefers circular objects.

Rochery et al. [40] have shown a phase field model that is equivalent to the HOAC models (i.e. sophisticated prior geometric knowledge can be included while maintaining the advantages of phase field models). Horváth and Jermyn [41] have described the conversion of the parameters of the HOAC GOC model to the phase field GOC model. It is important to note that the implementation of phase field HOAC model for road network extraction or the tree crown segmentation problems is two orders of magnitude faster due to the specific properties of the higher-order term in the phase field framework.

In this work we give solutions to overcome the limitations of previous methods keeping their advantageous properties. Our new models utilize shape information about objects of interests without predefining any template or reference shapes. The level set representation of active contour models allows us to handle multiple objects without increasing the complexity of the model. On behalf of morphology preserving segmentation we develop active contour methods that are capable of extracting touching or even overlapping objects in highly confluent images. By defining a multi-layered extension of the GOC model, we can successfully segment touching objects (see Chapter 2). We present an additive data model for fluorescent microscopy that is suitable to describe intensities coming from overlapping cell nuclei (see Chapter 3). To achieve computationally effective active contour based shape models we give a selective active contour framework which utilizes cheap and fast shape features to prefer various families of shapes (see Chapter 4).

\subsection{Object splitting}

The development of an automated, reliable segmentation method for cellular images is often challenging due to touching or overlapping cell nuclei clumps. Segmentation of individual cells is usually performed in two phases. In the presegmentation phase, localization of the foreground objects or the region of interest (single cells or clumps of cells) is performed, followed by the identification of individual cells in the clumps during the second phase.

Presegmentation methods include simple thresholding based on intensity [42] (e.g. Otsu segmentation) or variance measures [43]. Energy minimization methods, such as graph cut $[44,45]$ or active contour models $[27,46,47]$ are also employed with high efficiency in this area [48]. Other, machine learning based solutions were also developed for segmentation, if it is considered as a classification of image pixels [49].

In the second phase, cell nuclei clumps are separated into individuals. A huge number of automated methods for segmenting isolated cells have been developed, but most of them are not suitable to separate touching objects. However, other approaches 
have also been proposed to address this specific issue. The watershed method builds the segmented regions from local extrema of the image, and therefore, it often results in over-segmentation [50]. When the objects or the cells cannot be characterized by an extreme intensity in the center and monotonically changing intensity towards the boundary, more complex solutions are needed. Popular approaches attain the separation of cell clusters mainly based on two underlying principles: either the localization of individual cell centers $[51,52,53,54,55]$ or the concavity analysis of shape boundaries $[42,48]$.

Various methods have been developed to detect cell centroids since the accuracy of segmentation critically depends on them. The Hough transform for circular object detection is computationally expensive. Laplacian of Gaussian is also widely used for blob detection; it can be computed efficiently and it can exploit size information. A fast cell detection is achieved via voting based methods which utilize shifted Gaussian kernel and are guided by image gradients $[54,56]$. Some of the methods utilize a priori knowledge about the shape of individual objects. A large family of such priors assume object ellipticity $[57,58]$. These priors are highly effective for clusters of homogeneous objects, but can fail if the cluster is composed of diverse shapes. Other methods are based on wavelet analysis, and are able to detect cells, or 'spots', of a given size [59] or even of varying sizes [60]. However, these methods assume that the spots have near-circular shape and can result in over- or under-segmentation on elongated objects. Since in biological samples the shape and size of nuclei or cells, as well as their the texture may differ widely depending on the inner structure of the object of interest and the staining, the accurate localization of cell-center is still a challenging task.

After the first phase of applying these methods, once cell centers are determined, effective methods such as repulsive active contours [54], Voronoi tessellation [51, 61], gradient flow back-tracking [52] or watershed [53] are used.

Methods based on the cluster boundary information include: the minimum model approach [62], watershed based methods [63, 64], graph cut [42, 48] and rule based segmentation [65].

In Chapter 5 we present a cell segmentation framework which is developed for splitting object groups into individual cells, which is merely based on energy minimization principles. The assumptions for the input of this framework are:

- no intensity or edge information is available to separate touching objects;

- the individual objects of interest have an almost round boundary, and therefore the touching part can be described by concave points over the boundary of the object group.

These arguments have lead to a purely geometrical approach for splitting such shapes. By using an analogy from electrostatics, we define a novel HOAC model that moves opposite concave points of the contour towards each other if they satisfy the assumed geometry. 



\section{Chapter 2}

\section{Multi-layered 'gas of near-circles' models}

In this chapter we introduce a 'multi-layered' concept of commonly used variational segmentation methods. With our multi-layered 'gas of circles' phase field model we are able to extract an unknown number of near-circular objects from the image that may be positioned on top of each other, and therefore their segmentation is not restricted to disjoint regions of the image domain.

We start with a short introduction of the variational models for segmentation on which our multi-layered models are based. These models belong to the family of classical segmentation methods in the sense that they give the segmentation as a partitioning of the image domain to segments or regions with no common pixels.

Higher-order active contour (HOAC) models give a possible solution for templateless shape modelling [38]. They introduce long-range interactions between even nonneighbouring boundary points by using energy terms that involve multiple integrals over the boundary contour. The energy given this way does not require any training example shapes. Unlike those active contour models that incorporate template shapes, HOAC models are able to manage unknown topology of the extracted region(s), whether it belongs to an unknown number of separated objects or 'network-like' shapes, which cannot be described by a general reference shape or its perturbations. The basic concept of HOAC models are detailed in Section 2.1.

The 'gas of near-circles' model (GOC) is a special case of HOAC models. It defines the parameters of the energy functional to prefer configurations of separated stable circles of a given radius. To achieve this, the Taylor series of the energy to the second order around a circle of a radius $r_{0}$ was calculated. Setting the first order term of the Taylor series to zero and the second order term to positive definite constrains the parameters to have a minimum of the higher-order energy at that circle. The fundamental steps of stability analysis is described in Section 2.2 .

Phase field models are popular in physics for modelling interfacial dynamics. In our case, they can be considered as level set functions having advantageous properties, which make the usage of phase fields more effective compared to general level set concepts. The level set method is a commonly used technique to implement active contour models [33]. 
Rochery and colleagues have shown that under special circumstances equivalent phase field models can be created to the HOAC models. Thus we can use its advantages in handling topological changes, in initialization issues and in speeding the implementation [40]. Based on the work that studied the conversion of HOAC models to phase field representation, the phase field GOC model was introduced in [41]. In Section 2.3 we describe the relation of $\mathrm{HOAC}$ and phase field model parameters.

The common limitation of all these classical 'single-layer' methods which makes them unusable in several applications is that their segmentation result is a partitioning of the image domain, and therefore they cannot extract accurate boundaries of overlapping objects. Usually these segmentations split the overlapping object-pair somewhere in the middle of the area formed by the overlapping part of the two separate real life objects, e.g. in the set of those pixels which gain their intensity from the contribution of both objects. In Section 2.4 we show a natural and intuitive multi-layered extension of the classical phase field GOC model, in which touching or overlapping objects can be expressed by existing on different layers of the new model.

\subsection{Higher-order active contour model}

Rochery et al. [66] introduced a method using a new generation of active contours called higher-order active contours (HOAC) $[38,66]$. They proposed a novel energy term composed of multiple integrals over the contour and creating non-local interactions between contour points that can be relatively far from each other. One benefit of using this energy is that it is possible to describe families of shapes without using templates. They used the proposed model to detect road networks in aerial images. They extended the above model with a more complex prior term to close gaps on the road structure [67]. One of the simplest of these higher-order functionals is [68]:

$$
E_{C, g}(\gamma)=\lambda_{C} L(\gamma)+\alpha_{C} A(\gamma)-\frac{\beta_{C}}{2} \iint d p d p^{\prime} t(p) \cdot t\left(p^{\prime}\right) \Psi\left(r\left(p, p^{\prime}\right), d\right)
$$

where $t$ is the tangent vector to the contour; $p$ and $p^{t}$ are contour parameters; and $r\left(p, p^{\prime}\right)$ is the distance between the points $\gamma(p)$ and $\gamma\left(p^{\prime}\right)$. The interaction function $\Psi$, which was chosen here to be a monotonically decreasing function, controls the nature of the long-range interaction; it has a parameter $d$ that controls the interaction range.

For certain ranges of the parameters, the energy Eq. (2.1) favours regions in the form of networks, consisting of long narrow arms with approximately parallel sides, joined together at junctions, as described by Rochery et al. [38, 66]. Fig. 2.1 gives an explanation on the reason of appearing network shapes. Without the quadratic term the region tries to be as small as possible, both in terms of area and boundary length. With the quadratic term, if we have a situation presented in the middle of Fig. 2.1, there is no energy increase coming from the quadratic term if the region becomes smaller. But, if the region turns so small that its opposite boundary is closer than a certain distance controlled by $\Psi$, then the situation illustrated on the right image can be observed. This 
situation is not favoured, so the energy tends to avoid it. The possible way to do so, is to stop somewhere, where this unfavourable energy is not strong, in other words to stop at the equilibrium, where the quadratic energy is as strong as the rest is. This equilibrium can be a road network with a given road width or, as we will discuss in the next section, it can also be a stable circle, with radius influenced by the interaction function.
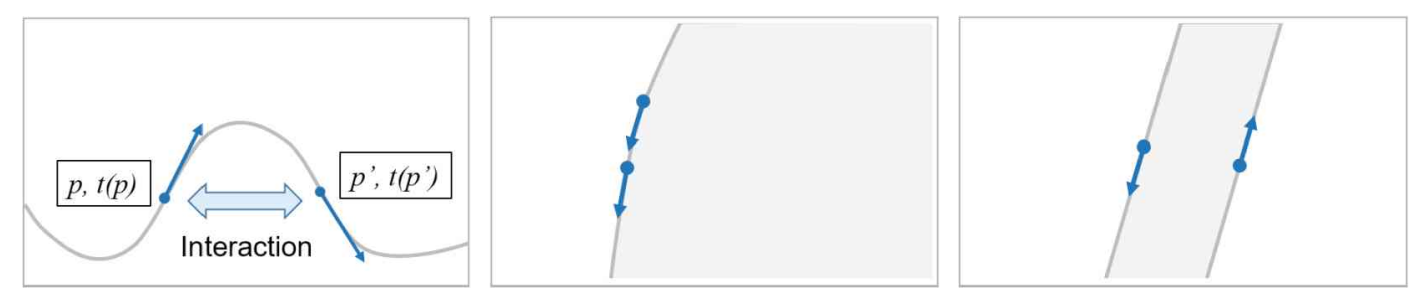

Figure 2.1: Interaction of boundary points by the quadratic term in Eq. (2.1) (left: general configuration, middle: aligned tangentials, right: tangentials with opposite directions). The right configuration is penalized by the quadratic term if the two contour points are too close.

The energy $E_{C, g}$ thus provides a good prior for network extraction from images. The data term was based on the gradient of the image [68].

\section{2 'Gas of near-circles' active contour model}

The creation of network structures by the HOAC model is affected by tuning the coefficients in the higher-order energy. This tuning is derived by a stability analysis of the energy functional. Here we will present the main idea that drives the parameter constrains in case of the GOC model, which prefers configurations of a set of stable circles at a given radius $r_{0}$ (Fig. 2.2). To achieve this behaviour the energy functional evaluated on a circular shaped contour should give low values. The stability of a circular shape means that if slight changes are applied to the circle, it will converge back to the circle shape of radius $r_{0}$.

Energy can be described as $E_{C, g}(\gamma)=E_{C, g}\left(\gamma_{0}+\delta \gamma\right)$, where $\gamma_{0}$ is a circle of radius $r_{0}$ and $\delta \gamma$ is the perturbation added [39]. Then we can approximate $E_{C, g}$ with Taylor series to the second order. To have $\gamma_{0}$ as the minima of $E_{C, g}$ we need the first order term to be zero and the second order term to be positive definite. These two restrictions determine the connection between the main parameters $\lambda_{C}, \alpha_{C}, \beta_{C}$ of the HOAC model and the preferred radius $r_{0} . \lambda_{C}=1$ can be fixed without loss of generality since it has only a scaling role in Eq. (2.1). $\alpha_{C}$ weights the area term in the energy, and thus increasing this parameter results in less area covered by foreground objects. $r_{0}$ is determined by the application. Based on the above derivation, $\beta_{C}$ can be given by a function of the other parameters mentioned. 


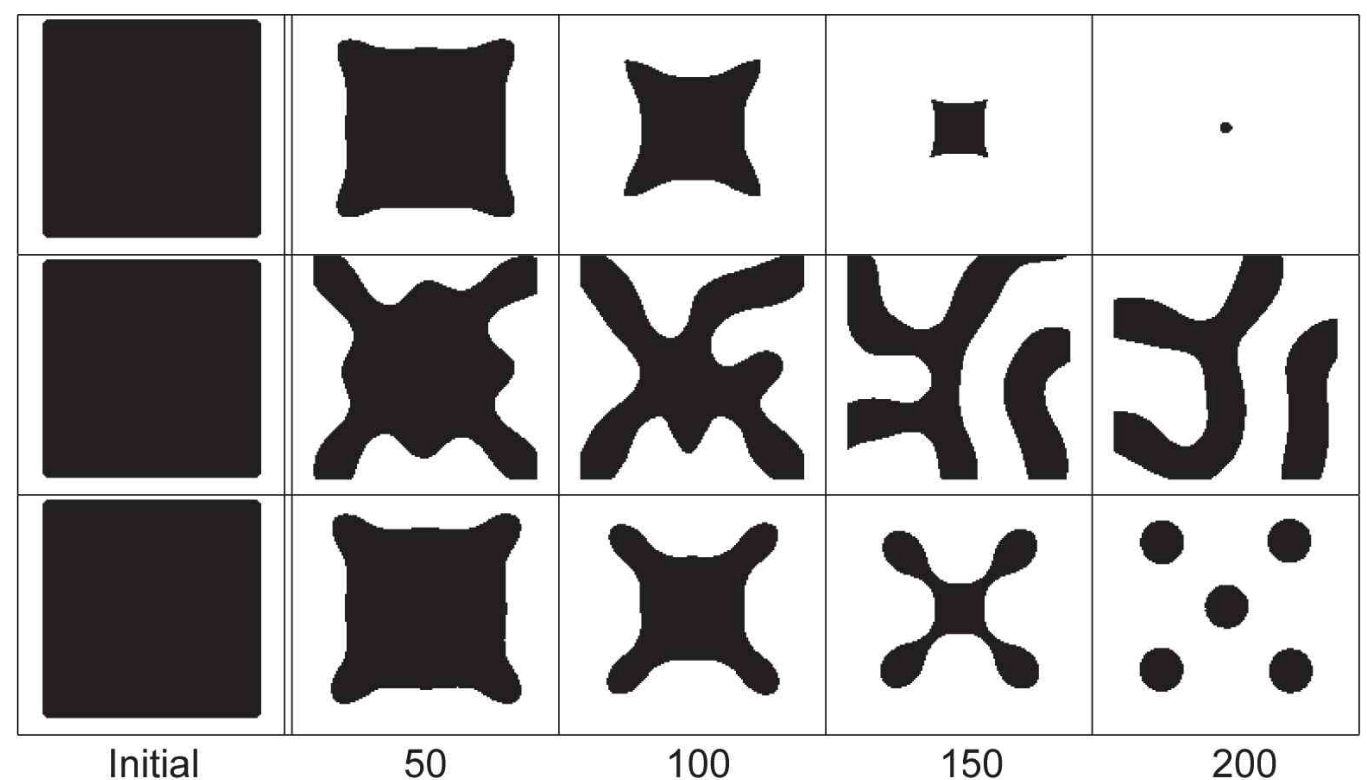

Figure 2.2: Curve evolution using different HOAC parameter sets. Starting from the same initial region (left) we can get different behaviour of the contour: the top row is the case of a weak quadratic term; in the middle row we get network-like configurations; in the bottom row we can see the effect of the 'gas of circles' parametrization [39].

\section{3 'Gas of near-circles' phase field model}

Phase field models are well known in physics and are used for solving interfacial problems. In [40], the authors introduced a phase field model, considered as a special level set framework, for image segmentation. They proposed an equivalent higher-order phase field model to the HOAC model, which allows to achieve faster energy minimization. They applied the phase field version of their HOAC network model to solve the road network extraction problem. In [41], an extension of Rochery's phase field model to the GOC phase field model was derived and was applied to tree crown extraction.

The phase field function $\phi$ is a level set function on $\Omega$. For a given threshold $z, \phi$ defines regions in the space of all possible regions $\mathcal{R}$ with a map $\zeta_{z}(\phi) \in \mathcal{R}=\{x \in \Omega$ : $\phi(x)>z\}$. In contrast to many other segmentation methods which use representation spaces isomorphic to $\mathcal{R}$ (e.g. snakes, distance functions), there is no constraint on $\phi$ : it can be any element of a linear function space, and thus many functions correspond to the same region. One of the simplest phase field energies can be formulated as: 


$$
\begin{aligned}
E_{f, g}(\phi) & =\int_{\Omega}\{\overbrace{\frac{D_{f}}{2}|\nabla \phi|^{2}+\underbrace{\alpha_{f}\left(\phi-\frac{\phi^{3}}{3}\right)+\lambda_{f}\left(\frac{\phi^{4}}{4}-\frac{\phi^{2}}{2}\right)}_{V}\}}^{E_{f, 0}} \\
& -\frac{\beta_{f}}{2} \iint_{\Omega \times \Omega^{\prime}} \nabla \phi \mathrm{G}\left(x, x^{\prime}\right) \nabla \phi^{\prime},
\end{aligned}
$$

where (un)primed functions are evaluated at $(x \in \Omega) x^{\prime} \in \Omega^{\prime} \equiv \Omega$. The interaction function $\mathbf{G}\left(x, x^{\prime}\right)=\Psi\left(\left|x-x^{\prime}\right|\right) \mathbf{I}$, where $\mathbf{I}$ is the $2 \times 2$ unit matrix. $E_{f, 0}$ has special properties: if $\lambda_{f} \geq\left|\alpha_{f}\right|$, the potential $V$ has two minima at \pm 1 , and a maximum at $\alpha_{f} / \lambda_{f}$. This offers the major advantages of using phase field models: first, we do not need to set a special initial region since we can start $\phi_{\text {init }}=\alpha_{f} / \lambda_{f}{ }^{1}$, from the value corresponds to the potential maximum; second, no reinitialization or other ad hoc regularization of the phase field are required since the potential forces its values to \pm 1 .

To find the equivalence between the $\mathrm{HOAC}$ and the phase field models, we can calculate the parameters' conversion by using a simplified model of the phase field [41]. Split the image domain into 3 parts based on a fixed region $R: R_{\gamma}$ is a narrow region of width $\tilde{w}$ around the boundary of $R ; R_{+}=R \backslash R_{\gamma}$ and $R_{-}=\bar{R} \backslash R_{\gamma}$ are the interior and exterior regions respectively. The simplified phase field $\tilde{\phi}$ has values \pm 1 over $R_{ \pm}$respectively, while over the interface region $R_{\gamma} \tilde{\phi}$ changes between \pm 1 . After the substitution of $\tilde{\phi}$ into Eq. (2.2) and pairing the resulted quantities with the ones of the HOAC model, one can find the connection between the parameters of the two models. Therefore, the phase field energy $E_{f, g}$, to a good approximation, is equivalent to the energy $E_{C, g}$ of the HOAC model by considering some restrictions on the parameters. This construction preserves the geometric behaviour of the HOAC model. In addition, it brings the advantages of the phase field model into the picture.

\subsection{Multi-layered 'gas of near-circles' phase field model}

The GOC model, whether in its active contour or phase field formulation, has two main limitations. The first one comes from the representation: like most segmentation methods, it cannot represent overlapping object instances since the solution is given as a partitioning of the image domain into disjoint regions. The second limitation arises from the geometric model itself: the non-local energy term, which causes the model to favour near-circular shapes, also results in a repulsive force between neighbouring objects separated by a distance comparable to the desired object size.

The HOAC energies of 2 circles in increasing distances are plotted in Fig. 2.3. It is clearly visible that in the case of 2 touching circles we get the highest energy, which

\footnotetext{
${ }^{1}$ In our experiments we used a Gaussian white noise with mean $\alpha_{f} / \lambda_{f}$ and very small variance.
} 
means it is not a stable configuration. Evolution of the phase field starting from these configurations is shown in Fig. 2.4. It shows that the 'single-layer' GOC model keeps 2 neighbouring objects separate only if there is a small distance over $0.33 r_{0}$ between them. Over this distance the repulsive force works until the neighbouring objects move out of the range of interaction. Consequently, this method cannot effectively handle objects that are close to each other or are overlapping.

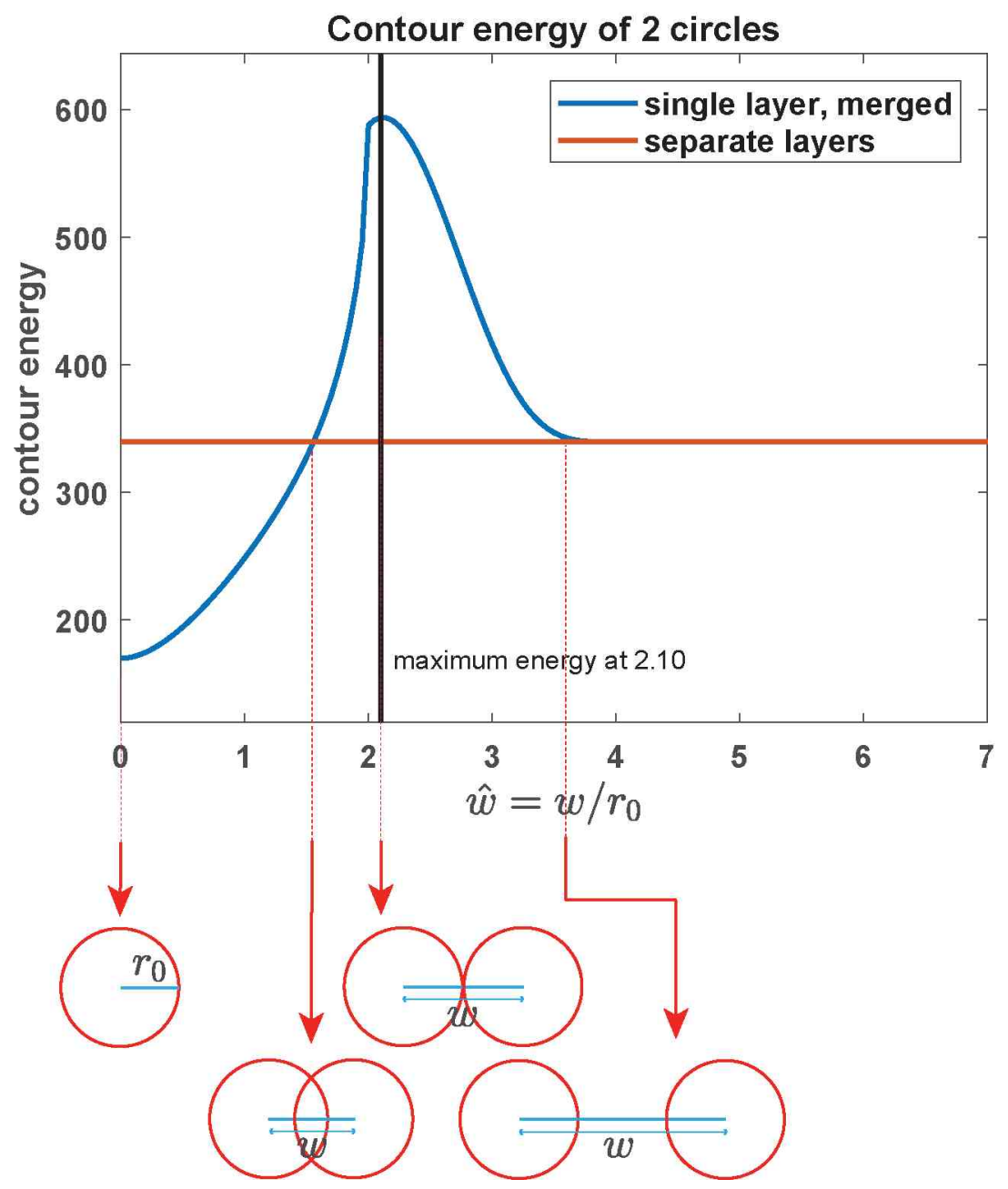

Figure 2.3: Contour energy of 2 circles in distance of increasing values. $\hat{w}=w / r_{0}$ is the normalized distance of the 2 interacting circles, where $w$ is the distance and $r_{0}$ is the preferred radius.

In the following section we introduce an extension of the presented GOC method in which we eliminate all the mentioned weaknesses of it. 


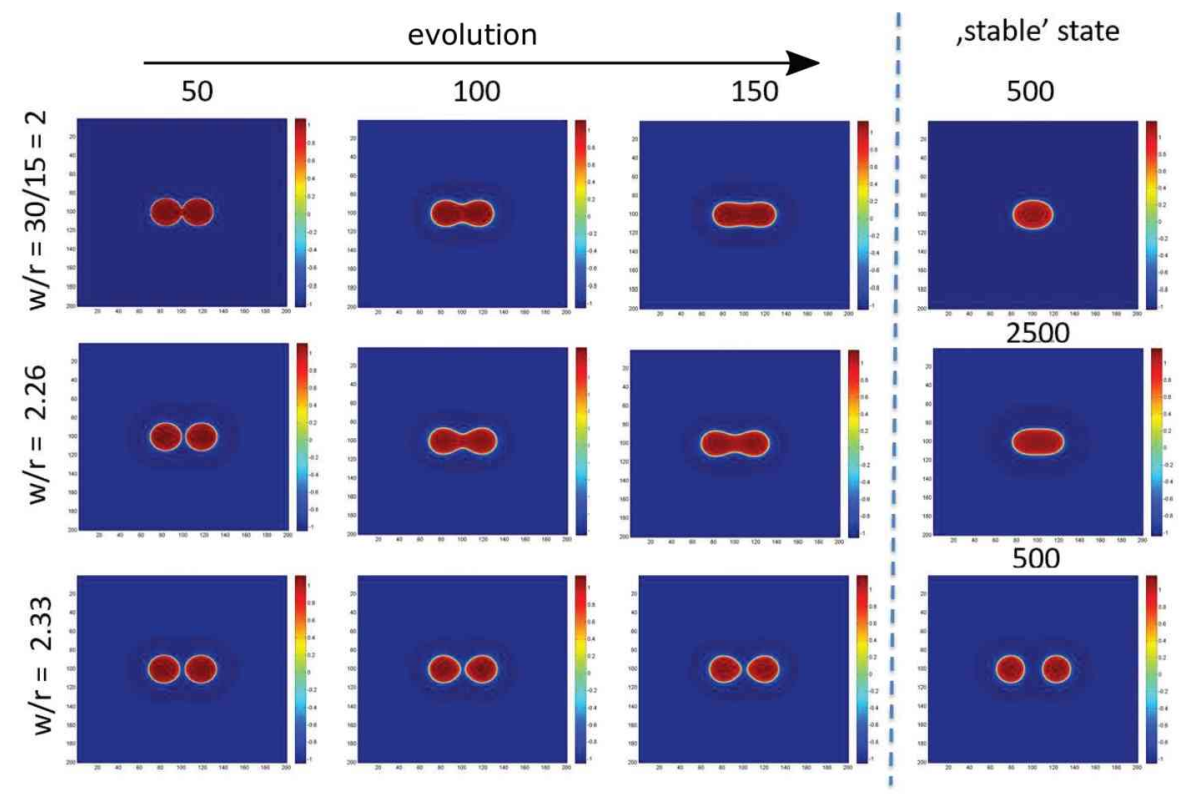

Figure 2.4: Evolution of the phase field GOC model of 2 circles starting from increasing distance. Objects that are closer than $2.33 r_{0}$ slowly start to merge during the evolution. Here we use 'stable' for a configuration which has the topology of the final configuration.

\subsubsection{Dealing with overlapping: geometric model}

Now we extend the single-layer model of Eq. (2.2) to a multi-layered GOC model [69]. The use of multiple instances of the classical models enables the representation of not only disjoint subsets, but sets of subsets of $\Omega$ possibly having non-empty intersection, which can now be represented on separate layers. Formally it means that the definition of segmentation needs to be changed slightly: condition ii, which prevents that two different regions to have common pixels, can be omitted. As a result, the new model can represent objects that touch and overlap in the image (Fig. 2.5).

Moreover, the long-range interaction in Eq. (2.2) creates a repulsion between connected components. This repulsive force favours configurations in which the objects are separated by a distance comparable to their size. While it is appropriate for some tasks, e.g. tree crowns in regular plantations [41], it fails in solving problems in which objects are touching or overlapping. To overcome this limitation, in the new model the long-range interactions act intra-layer but not inter-layer [69]. This has two effects. First, the low-energy configurations in each layer are still 'gas of near-circles' configurations, as required. Second, the repulsive interaction is eliminated, because repulsively interacting regions can exist on separate layers. The result is that overlapping 'gas of circles' configurations on separate layers can now be combined without penalty. However, to avoid degenerate configurations, in which a given object is duplicated across all layers, an inter-layer area overlap penalty is introduced [69].

To proceed, we redefine the phase field as a multi-component object: $\Phi=\left\{\phi^{(i)}\right\}_{i \in[1 . . \ell]}$ : 


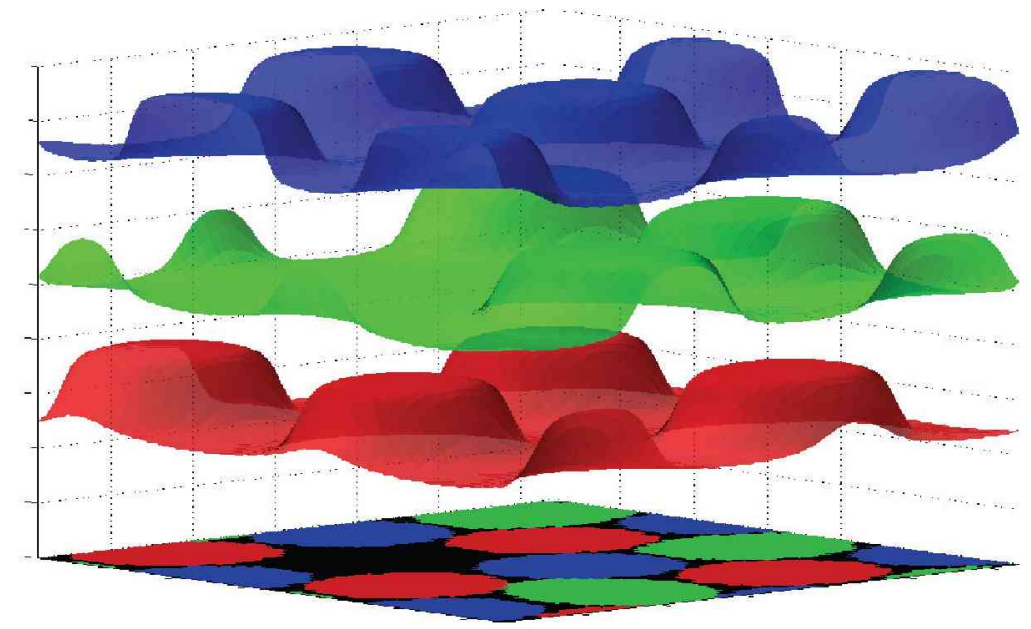

Figure 2.5: Multi-layered 'gas of $\operatorname{circles}^{6}$ (MLGOC) phase field model. Three surfaces illustrate a stable configuration of the MLGOC model. Under the surfaces there is the corresponding segmentation. Positive overlap penalty forces the segmented regions to move in positions not having overlap with other regions from other layers.

$[1 . . \ell] \times \Omega \rightarrow \mathbb{R}$, where $\ell$ is the number of layers. The total energy $\tilde{E}_{f}$ of the new multilayered model then takes the form

$$
\tilde{E}_{f}(\Phi)=\sum_{i=1}^{\ell} E_{f, g}\left(\phi^{(i)}\right)+\frac{\kappa_{O}}{4} \sum_{i \neq j} \int_{\Omega}\left(1+\phi^{(i)}\right)\left(1+\phi^{(j)}\right),
$$

where $E_{f, g}$ is defined in Eq. (2.2), and $\kappa_{O}$ is a new parameter controlling the strength of the overlap penalty.

Here are some observations about the effects of overlap penalty:

- As expected, $\kappa_{O}=0$ yields overlapping objects, while $\kappa_{O}>0$ prevents overlaps (an example of a low-energy configuration is shown in Fig. 2.5).

- From Eq. (2.3), 'background' points, with $\phi^{(i)} \simeq-1$, do not generate overlap penalty.

- If they do not overlap, objects in range of the repulsive interaction will tend to lie in different layers (see Fig. 2.6).

- If they do overlap, there is competition between the repulsive interaction and the overlap penalty (see Fig. 2.6).

- If $\kappa_{O}$ is not too large, the objects will exist on separate layers; if $\kappa_{O}$ is large enough, they will exist on the same layer, perhaps reducing to one object (see Fig. 2.6). 
- If $\kappa_{O}$ is too high, then either an empty configuration or unstable circles are produced.

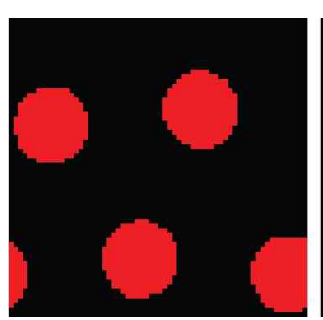

$$
\ell=1
$$

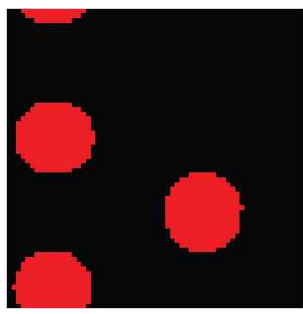

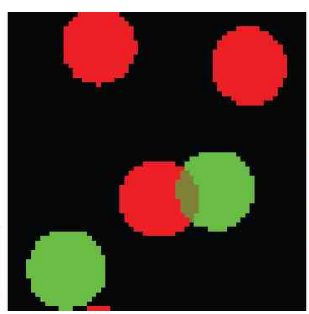

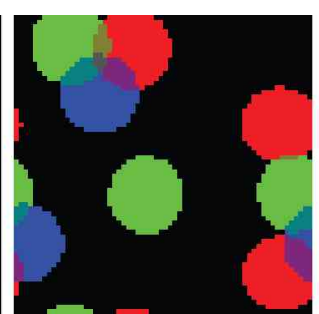

$$
\ell=3
$$
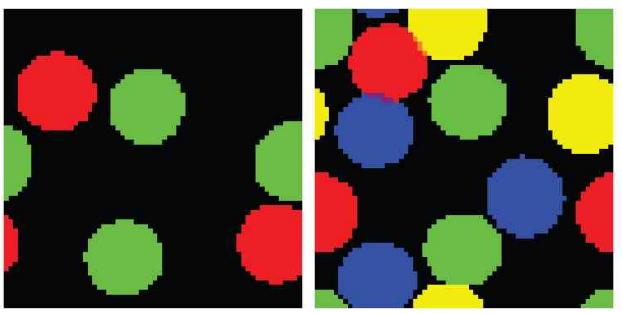

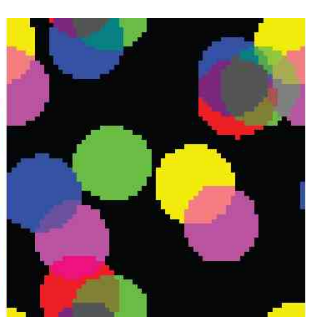

$\ell=5$

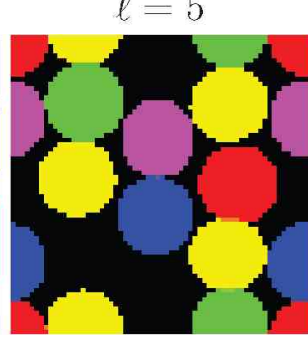

Figure 2.6: Typical configurations of the prior model $\left(r_{0}=10\right.$, negative circle energy) using different number of layers $(\ell)$. The weight of overlap penalty $\kappa_{O}=0$ in the top row and $\kappa_{O}=0.02$ in the bottom row.

\subsubsection{Functional derivative of the energy}

The multi-layered phase field energy will be minimized via gradient descent, for which we need to compute its functional derivative with respect to each phase field layer [69]:

$$
\frac{\delta \tilde{E}_{f}(\Phi)}{\delta \phi^{(k)}\left(x^{\prime}\right)}=\sum_{i=1}^{\ell} \frac{\delta E_{f, g}\left(\phi_{k}\right)}{\delta \phi^{(k)}\left(x^{\prime}\right)}+\frac{\kappa_{O}}{4} \frac{\delta E_{O}(\phi)}{\delta \phi^{(k)}\left(x^{\prime}\right)}
$$

where $E_{O}(\phi)$ denotes the overlap energy term from Eq. (2.3). The first term is simply the functional derivative of $E_{f, g}$ evaluated at the $\phi^{(k)}$, and so is known [40, 41]. The derivative of the overlap energy is (for more details see Appendix A)

$$
\begin{aligned}
\frac{\delta E_{O}(\phi)}{\delta \phi^{(k)}\left(x^{\prime}\right)} & =2 \sum_{i \neq j} \int_{\Omega} \delta_{i k} \delta\left(x, x^{\prime}\right)\left(1+\phi^{(j)}(x)\right) d x \\
& =2 \sum_{j \neq k}\left(1+\phi^{(j)}\left(x^{\prime}\right)\right) \\
& =2(\ell-1)+2 \sum_{j \neq k} \phi^{(j)}\left(x^{\prime}\right) .
\end{aligned}
$$




\section{$2.5 \quad$ Image data model}

In order to couple the geometric model to image data, we need a likelihood energy. For these experiments, we made two assumptions on the images to create this likelihood energy: first, the foreground and background pixel intensities follow two different normal distributions which can be calculated by maximum likelihood estimation; second, high image gradient can be measured between the foreground and background intensities. This is the case if the resolution is not high enough to resolve the texture of foreground of the objects ${ }^{2}$ (e.g. some type of lipid droplets of size of a few microns with resolution $\sim 0.4 \mu \mathrm{m})$. We used the following phase field data term:

$$
E_{I}(I, \phi)=\int_{\Omega}\left\{\gamma_{1} \nabla I \cdot \nabla \phi+\gamma_{2}\left[\frac{\left(I-\mu_{\text {in }}\right)^{2}}{2 \sigma_{\text {in }}^{2}} \phi_{+}+\frac{\left(I-\mu_{\text {out }}\right)^{2}}{2 \sigma_{\text {out }}^{2}} \phi_{-}\right]\right\},
$$

where: $\nabla \phi$, and $\phi_{ \pm}=(1 \pm \phi) / 2$ are approximately the normal vector to the boundary, and the characteristic functions of the region $(+)$ and its complement $(-)$ respectively [41]; $I: \Omega \rightarrow \mathbb{R}$ is the image data; $\mu_{\text {in,out }}$ and $\sigma_{\text {in,out }}$ are the parameters of pixel-wise Gaussian distributions modelling the image in the interior (in) and exterior (out) regions, learned from samples; and $\gamma_{1,2}$ are positive weights. Fig. 2.6 shows some minimum energy configurations of the prior model. Without loss of generality, we chose $d=10, \alpha_{f}=0.2795, \beta_{f}=0.0911, \lambda_{f}=0.625$ and $D_{f}=0.75$ to ensure the negative circle energy needed to have objects in the minimum energy configuration.

\subsection{Verification}

\subsubsection{Separation ability}

In the next experiment we took a closer look at the properties of the model in the case of two circles with different levels of overlap. We used two layers, circles of radius 10 , and $\kappa_{O}$ values in the range $[0,1]$. Fig. 2.7 shows pixel level segmentation error versus overlap penalty $\kappa_{O}$ and the degree of the overlap $w^{*}=2 * r_{0}-w$, where $r_{0}=10$ is the preferred radius and $w$ is the distance between the centroids of the two circles. Near $\kappa_{O}=0.7$ there is a clear fall in the segmentation error. If $w^{*}>r_{0}$, we need a larger $\kappa_{O}$ to achieve a good segmentation.

\subsubsection{Tuning data parameters}

We examined the relationship between the data weight $\gamma_{2}$, overlap penalty $\kappa_{O}$, and extraction accuracy on synthetic images with more than two touching circles. Fig. 2.8 shows the ratio of correctly detected circles as a function of $\kappa_{O}$ and $\gamma_{2}{ }^{3}$. It is clear

\footnotetext{
${ }^{2}$ Similar model was used to approximate the intensity distribution of aerial images of forests in [39].

${ }^{3}$ No false positive and false negative object detection values were achieved between the range of the used parameters.
} 


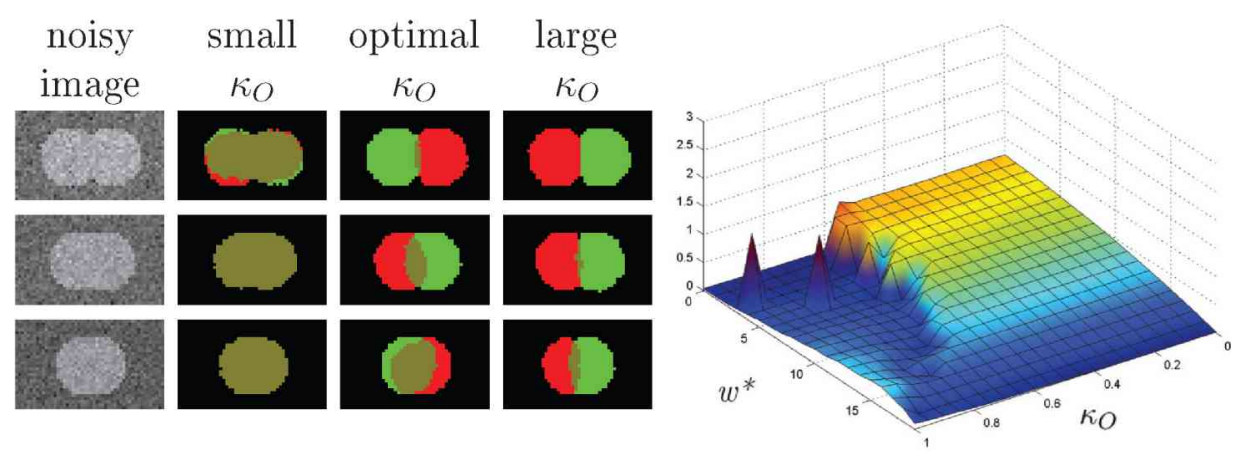

Figure 2.7: Segmentation results on noisy images containing two overlapping circles. The preferred radius $r_{0}$ was chosen to 10 . Left: overlap level $w^{*}: 5$ (top row); 10 (middle row); 15 (bottom row); small $\kappa_{O}=0.55$; optimal $\kappa_{O}=0.7\left(0.8\right.$ when $\left.w^{*}=15\right)$; large $\kappa_{O}=1$. Right: segmentation error at the pixel level (0 means perfect segmentation). The results were achieved by neutral initialization.
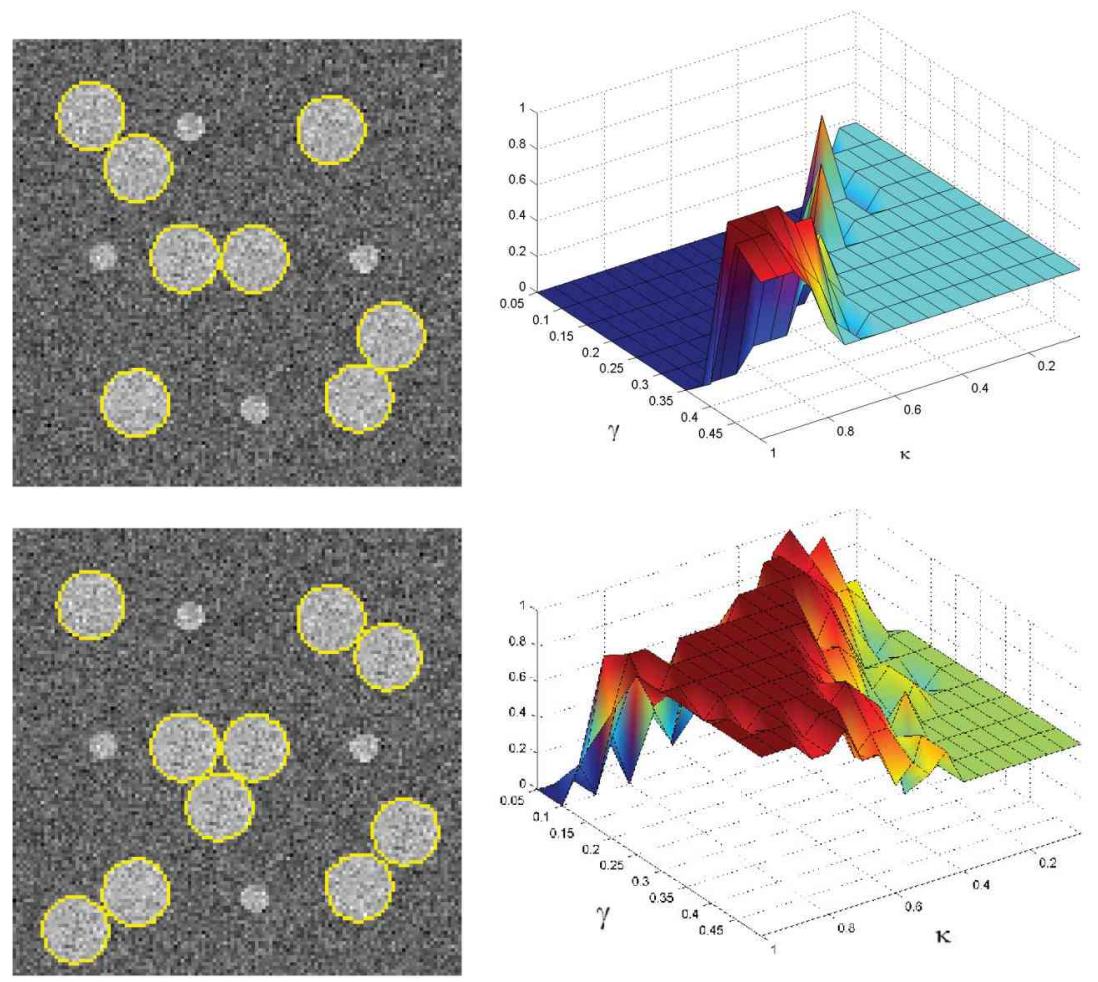

Figure 2.8: Results on synthetic images using neutral initialization. Left: segmentation; right: proportion of correctly detected circles (TP) as a function of $\kappa_{O}$ and $\gamma_{2}$. Note that false objects were not segmented in these ranges of $\kappa_{O}$ and $\gamma_{2}(\mathrm{FP}=0)$.

that there are several parameter pairs for which one can achieve a correct segmentation starting from a random initialization. 


\subsubsection{Implementation issues}

Computational complexity A significant advantage of using level sets or phase fields for representation of active contour models that the density of the information in the image (i.e. the number of objects) does not increases the computational complexity of the model. Since the segmented regions are uniquely defined by the level set and a given threshold at any point of its evolution, the increasing number of segmented objects have no unwanted effects on the computing costs of evolution. Of course in our new model we use the term multi-layered model, and therefore the amount of operations we need is multiple compared to the single layer model. The computational time is a linear function of the number of phase field layers used.

Initialization To initialize the multi-layered phase field, first we used a simple adaptive thresholding and connected component detection, plus random assignment of different layers to nearby initial regions. To define an upper limit for the number of layers, we can make some restrictions on the possible solutions without much loss of generality. Namely, we can assume that the density of interesting objects in the image is not too high. Our tests clearly showed that smart initialization improves the accuracy of the model, as it is typical in gradient methods. To make the number of layers as low as possible, we invoked the four colour theorem of graph theory. It states that no more than four colours is needed to colour each region of any separation of a plane so that no two adjacent regions have the same colour. We applied the map colouring theorem to our 'smart initialization' the following way:

- detect the center of the objects with any suitable method (from simple thresholding and separation of clumped objects by size to more sophisticated methods, e.g. a trous wavelet transform);

- consider two centers as adjacent regions (or in graph theory they are nodes with edge between them) if their distance is small enough (see Section 2.4);

- colour the constructed map (or graph) with four colours and this actual colouring will give the distribution of the seeds between the four layers;

- the initial state of each layer then is set to -1 all over the image domain except the small neighbourhood of the seeds where it is set to 1 .

This distribution of seeds can reduce the chance of getting two regions too close within the same layer, and therefore their merging (see Fig. 2.3). To make the implementation faster, the convolution of the actual phase field with the long-range interaction operator is executed in Fourier domain.

Boundary conditions The implementation of the quadratic term includes a convolution operation to calculate the interaction forces. For effective computation the convolution is performed in the frequency domain. Since the discrete Fourier transform 
is periodic, we had to deal with the segmentation of objects on the boundaries of the images. Phantom objects appearing from the opposite end of the image can result in false positive detections. To avoid this unwanted phenomena we padded the input image with the estimated intensity of background. The size of padding is set large enough to eliminate the unwanted effect of the interaction operator, and this size is $2 d$, half of the size of the geometric kernel that belongs to interaction operator. Compared to image size we work with ( $>1$ megapixel), it produces a negligible amount of extra computation. 



\section{Chapter 3}

\section{Additive data model for fluorescent microscopy}

This chapter introduces an additive image data model which is suitable for fluorescent microscopy since it captures the essence of image forming characteristic for this family of microscopes.

Fluorescent microscopy is a rapidly expanding technique, both in medical and biological sciences. This technique has made it possible to identify cells and cellular components with a high degree of specificity. For example, certain antibodies and disease conditions or impurities in inorganic materials can be studied using fluorescent microscopy.

Fluorescent microscopy is an optical type microscopy that uses fluorescence and phosphorescence instead of, or in addition to, reflection and absorption to study properties of organic or inorganic substances. In Section 3.1 we would like to give a general picture about the importance of fluorescent microscopy, the image acquisition and forming, and the possible applications of a data model that deals with the fluorescent phenomena of overlapping objects.
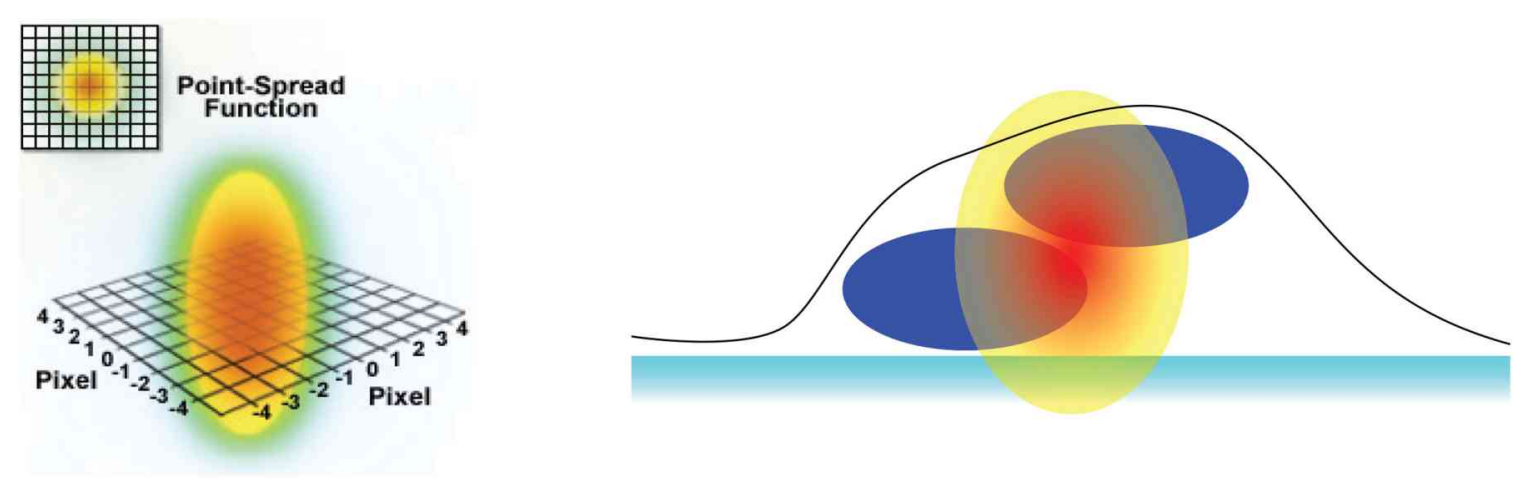

Figure 3.1: Examples of point spread function and image forming.

The acquired image and the whole optical system of a fluorescent microscope are defined by the microscope's points spread function (PSF) (see Fig. 3.1). By using the 
linearity of the imaging model of the optical imaging systems, such as (epi)fluorescent microscopes, we define an additive image term to supplement the MLGOC model. Via this additive 'meta' phase field, the autonomous GOC layers of the MLGOC model can co-operate with each other. Section 3.2 introduces the additive phase field image term, and in Section 3.3 we present the performance of the new model on synthetic and real images.

\subsection{Overlapping objects in imaging}

In recent years, both the academic and the industrial sectors have been increasingly interested in developing more complex three-dimensional cell culture models. These can better capture the complexity of the tissue, and have the potential to provide more biologically relevant information than two-dimensional models [70, 71, 72]. Upon the imaging of such models as simple 2D images, the objects (cells) of interest may easily overlap for several reasons. One possible case is dealing with tissue samples. The samples are sliced by a microtome to slices of 2-50 $\mu \mathrm{m}$ thickness depending on the precision of the machine. To safely handle a slice, i.e. to avoid an unwanted tearing, its thickness should exceed a certain minimum $(5-10 \mu \mathrm{m})$. The minimum thickness is also restricted by further investigations, i.e. it should definitely exceed the diameter of a nuclei (typical diameters ranging between 2 and 10 microns) or cell (typically 10$30 \mu \mathrm{m}$, except for mature female eggs that are among the largest cell types with a diameter of about $120 \mu \mathrm{m}$ ) when single cell based molecular analysis is required, to make sure that we have all the necessary biological material. In brain tissue samples cell density is very high. Therefore, it is reasonably frequent that nuclei are located over each other. Another typical situation for overlapping cells includes tumour experiments with aggressively growing tumour cells, which have lost contact inhibition. Co-cultures of different cell types in 2D provide similar challenges with many overlapping cells. This phenomenon is inevitable since it results from the biological behaviour of the cells, not a removable artifact originating from the imaging system or sample preparation.

In the following section we give a short introduction on fluorescent microscopy. The specimen of interest is illuminated with light of a specific wavelength (or wavelengths) which is absorbed by fluorophores. Illumination causes them to emit light of longer wavelengths (i.e. of a different colour than the absorbed light). This way the distribution of a single fluorophore is imaged at a time, which means that, compared to bright field microscopy, the sample you study is the light source itself. Fluorophores are chemical compounds covalently bonded to a macromolecule, serving as a marker (or dye, or tag, or reporter) for affine or bioactive reagents (antibodies, peptides, nucleic acids). In our experiments we worked on images acquired from cell nuclei, i.e. the image channels are formed by the fluorophores bonded to nuclear DNA (e.g. DAPI, Hoechst).

The point spread function (PSF) plays an important role in the image formation theory of the (fluorescent) microscope. It is the main brick that builds up the whole acquired image. The PSF of an optical device is the image of a single point object (rescaled to make its integral all over the space equal 1). The degree of spreading 


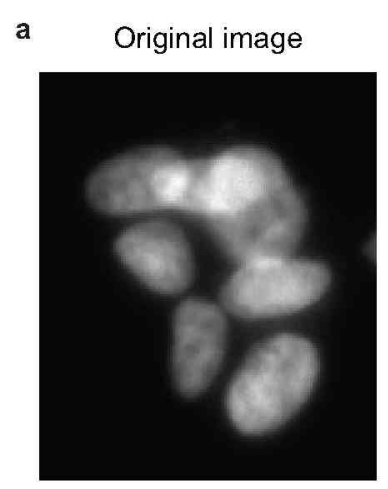

b Adaptive threshold

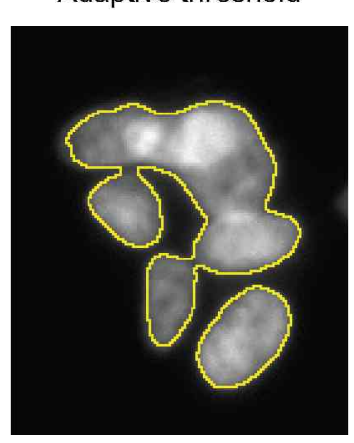

c Adaptive threshold+
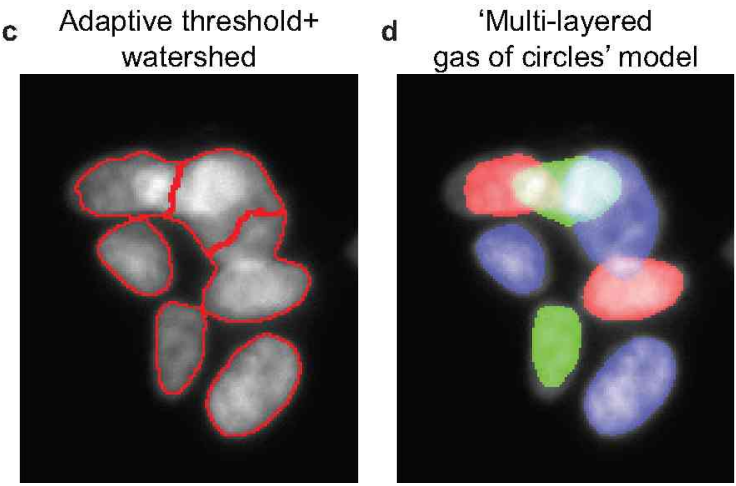

e

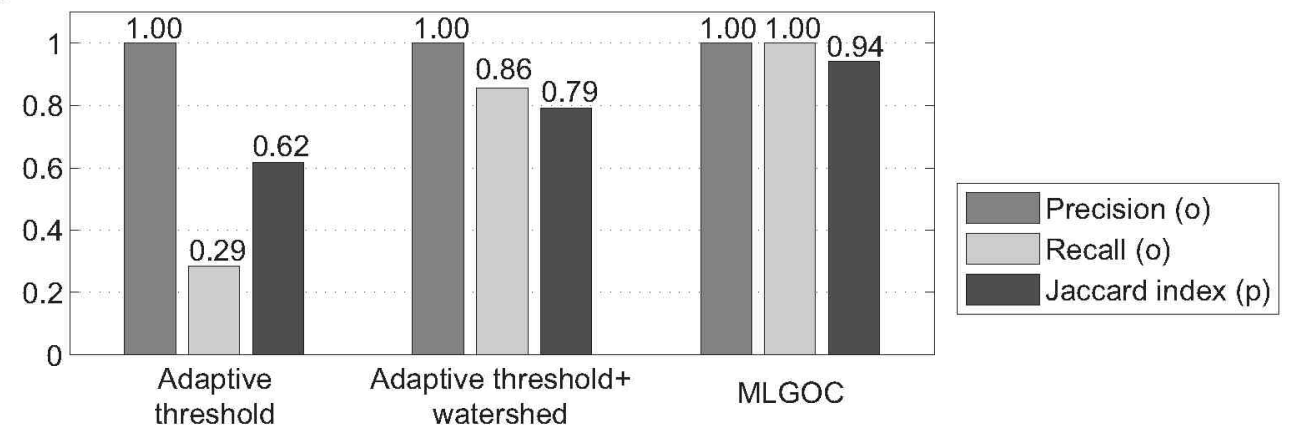

Figure 3.2: Comparison of different methods on microscopic images containing overlapping cells. Top row from left to right: (a) Original image; (b) Results (Region of Interest) obtained by adaptive Otsu thresholding (c) Results of the standard watershed segmentation method; (d) Results with the proposed 'multi-layer gas of near-circles' method; (e) Precision, recall and Jaccard index of segmented objects ('o' and 'p' indicate that the metrics are computed at the object and pixel level, respectively).

(blurring) in the image of this point object is a measure for the quality of an optical system. The PSF is the 'brick' of the image because in incoherent imaging systems such as fluorescent microscopes the image formation process is linear and described by linear system theory. This means that when two objects $A$ and $B$ are imaged simultaneously, the result is equal to the sum of the independently imaged objects. In other words: the imaging of $A$ is unaffected by the imaging of $B$ and vice versa. As a result of this linear property, the image of any object can be computed by chopping up the object in parts, image each of these, and subsequently sum the results. When one chops up the object in extremely small parts, i.e. point objects, the image is computed as a sum of PSFs, each shifted to the location and scaled according to the intensity of the corresponding point. This is mathematically represented by a convolution equation:

$$
I(x, y)=O * P S F=\iint O(u, v) P S F(x-u, y-v) d u d v
$$

where $O(u, v)$ is the intensity of the emitted light of the particle at position $(u, v) ; P S F$ : $\mathbb{R}^{3} \rightarrow \mathbb{R}$ is the point spread function of the microscope. It gives that the measured 
intensities of the acquired image are proportional to the number of the fluorophores in the range of PSF. In conclusion, the imaging in the fluorescent microscope is completely described by its PSF.

Note that a similar effect is observable in other types of microscopy such as bright field or electron microscopy. In these techniques the image forming is based on the absorption of the source light or electron when transmitting it through the specimen. The typical appearance of images acquired via these techniques is a dark sample on a bright background. The darkness of the objects in the image depends on the thickness and density of the sample. Due to occlusion and absorption of light/electrons in the sample, thicker and denser parts (or regions with a higher atomic number) of the sample yield darker/lower intensities. However, the measured intensity is not linear in the thickness of the specimen in all types of microscopy.

Image formation model for overlapping cell nuclei The image formation model we use is $I_{\text {observed }}=I_{\text {background }}+I_{\text {original }}$, where it is assumed that illumination problems have already been corrected [73]. $I_{\text {background }}$ is a nearly flat non-zero surface with noise, so-called 'dark noise'. Let $\mu_{-}$and $\sigma_{-}^{2}$ be the mean and variance of the background intensity, and $\mu_{+}$and $\sigma_{+}^{2}$ be the mean and variance of the measured intensity of a single cell. Let $\Delta \mu=\mu_{+}^{2}-\mu_{-}^{2}$, and $\Delta \sigma^{2}=\sigma_{+}^{2}-\sigma_{-}^{2}$. Then, according to the model, the mean of the intensity of multiple cells is given by $\mu_{-}+n \Delta \mu$, and its variance by $\sigma_{-}^{2}+n \Delta \sigma^{2}$. The parameters $\mu_{-}, \sigma_{-}^{2}, \Delta \mu$, and $\Delta \sigma^{2}$ are estimated from the corrected images using maximum likelihood estimation.

\subsection{Data model for overlapping objects/cells}

In this section we introduce a new data model which is adapted to the image formation process in fluorescent imaging. The new model is constructed using the assumption that overlapping cells additively contribute to pixel intensities of the acquired image, so that multiple cells on top of each other produce an intensity contribution that is a multiple of that of a single cell.

Let $\phi_{+}=\sum_{i=1}^{\ell} \frac{\left(\tanh \left(\phi^{(i)}\right)+1\right)}{2}$ (Fig. 3.3), where $\phi^{(i)}$ is the phase field in the $i^{\text {th }}$ layer; this quantity "counts" the number of cells at each point. Let $\gamma_{d}$ be the (positive) weight of the data term; and let $I$ be the intensity of the input image. Using the image formation model described earlier, and a Gaussian model for the image noise, the new data term becomes [74]:

$$
E_{\text {intensity }}\left(I, \phi_{+}\right)=\gamma_{d} \int_{\Omega} \frac{\left(I-\mu_{-}-\Delta \mu \phi_{+}\right)^{2}}{2\left(\sigma_{-}^{2}+\Delta \sigma^{2} \phi_{+}\right)} d x
$$

Since a phase field takes the values -1 and 1 in its two stable phases of the energy potential (background and foreground), with a smooth transition between them, the integrand in Eq. (5), which is the energy density, takes a low value when $\phi_{+}=0$ over regions with background intensity; $\phi_{+}=1$ over regions of single-cell intensity; and generally, when $\phi_{+}=n$ over regions with $n$ cell intensity. 

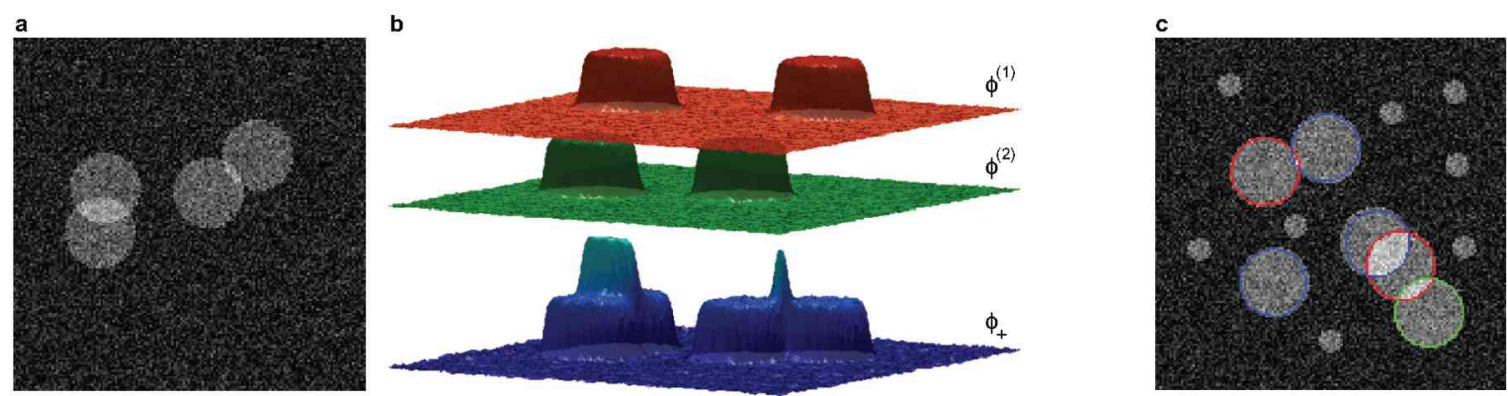

Figure 3.3: Illustration of the proposed data model and behaviour of the geometric model. (a) Noisy synthetic image. (b) Phase field representation of the cell configuration in image (a), showing the two layers, and the combined $\phi_{+}$function that "counts" cells. (c) Size selectivity of the GOC model: using proper settings of the prior and data parameters, it is possible to achieve size-selective segmentation. No initial object seeds were used.

We use gradient descent in order to minimize the overall energy $E=E_{\text {intensity }}\left(\phi_{+}\right)+$ $\sum_{i} E_{\text {geom }}\left(\phi^{(i)}\right)$ and find the optimal phase field configuration, and hence segmentation. The functional derivative of $E_{\text {geom }}$ is given in [40]. The functional derivative of $E_{\text {intensity }}$ is [74]

$$
\begin{aligned}
\frac{\delta E_{\text {intensity }}}{\delta \phi^{(k)}}= & \frac{\gamma_{d}}{4} \operatorname{sech}^{2}\left(\phi^{(k)}\right)\left[\frac{\Delta \mu^{2} \Delta \sigma^{2} \phi_{+}^{2}+2 \Delta \mu^{2} \sigma_{-}^{2} \phi_{+}}{\left(\sigma_{-}^{2}+\Delta \sigma^{2} \phi_{+}\right)^{2}}\right. \\
& \left.+\frac{-2 \Delta \mu \sigma_{-}^{2}\left(I-\mu_{-}\right)-\Delta \sigma^{2}\left(I-\mu_{-}\right)^{2}}{\left(\sigma_{-}^{2}+\Delta \sigma^{2} \phi_{+}\right)^{2}}\right]
\end{aligned}
$$

where sech stands for hyperbolic secant (for further details see Appendix A).

\subsection{Verification}

In order to measure the robustness of the proposed method, we generated data sets of synthetic images with different values for the noise variance, the extent of overlap, and varying object ellipticity and size, to create variability similar to that seen in real world observations [75].

\subsubsection{Evaluation and metrics}

To evaluate the algorithm and to compare it to other methods, three metrics were used. The first two metrics are the precision and recall of object detection. Precision (or positive prediction value) is the ratio of true positives (TP) to the number of detected objects $($ Precision $=\mathrm{TP} /(\mathrm{TP}+\mathrm{FP})$ ). Recall (or sensitivity) shows what proportion of the objects of interest is found (Recall $=\mathrm{TP} /(\mathrm{TP}+\mathrm{FN}))$. Values closer to 1 imply better 
detection. Values are computed as follows. First, a matching is made between the set of ground truth objects and the set of segmented objects. Objects with no overlaps with any other objects are deemed unmatched. A weight is then assigned to each pair of remaining segmented and ground truth objects, equal to the reciprocal of the area of overlap. The total weight of a matching is defined as the sum of the weights of the matched pairs. This is an instance of the assignment problem; we solve it with the Hungarian algorithm. TP is then the number of segmented objects which have a matching ground truth object, while FP is the number of segmented objects that have no matching ground truth object. FN is the number of ground truth objects which have no matching segmented object. Note that these metrics do not measure morphological accuracy. The third metric measures the morphological accuracy of the segmentations of individual, correctly-detected objects. For each matched pair of segmented (A) and ground truth (B) objects, we compute the Jaccard index, the ratio of the area of their intersection to the area of their union: $\operatorname{JI}(A, B)=|A \cap B| /|A \cup B|$. The final measure is then the average of the Jaccard indices of the matched pairs.

\subsubsection{Dependence on initialization}

Gradient descent methods search for a local optimum of the target energy function. Initialization is therefore crucial: a good initialization can greatly increase the accuracy of the resulting segmentation. We use two initialization methods:

- 'Neutral initialization' means that the initial phase field is a realization of Gaussian white noise with mean $\lambda_{f} / \alpha_{f}$ and a small variance [40].

- 'Seeded initialization' means that we have estimates of the 'centers' of the objects, the 'seeds'. These could be computed by any available method; they are currently given manually. The initial phase field is defined to be 1 at all points within half the preferred radius of a seed, and -1 elsewhere. The seeds are distributed among the layers so as to minimize overlaps (see Section 2.6.3).

To compare the 'Neutral' and 'Seeded' initialization methods, 60 synthetic images (of size $400 \times 400$ pixels) containing $\{30,35,40\}$ circles of radius 15 , and 140 synthetic images (of size $150 \times 150$ ) containing $4-10$ circles of radius 15 were generated (with $10 \mathrm{~dB}$ signal-to-noise ratio level). Background and foreground intensities were chosen from sets $\{30,40,50\}$ and $\{90,100,110\}$, respectively, for 8-bit grayscale images. The set of synthetic images thus contains $6,300+6,860=13,160$ perfect circles with different degrees of overlap $(0-100 \%)$. Fig. 3.4 shows that the manual, seeded initialization makes the model 4-5\% more effective at pixel level segmentation accuracy, without loss of object detection accuracy: with an appropriate choice of data weight, the manual initialization performs better than the neutral initialization with respect to all measures.

\subsubsection{Object size selectivity}

To analyze the ability of our model to select objects of the correct size, a set of images was generated containing circles of two radii: 5 and 15. The expected radius of the 

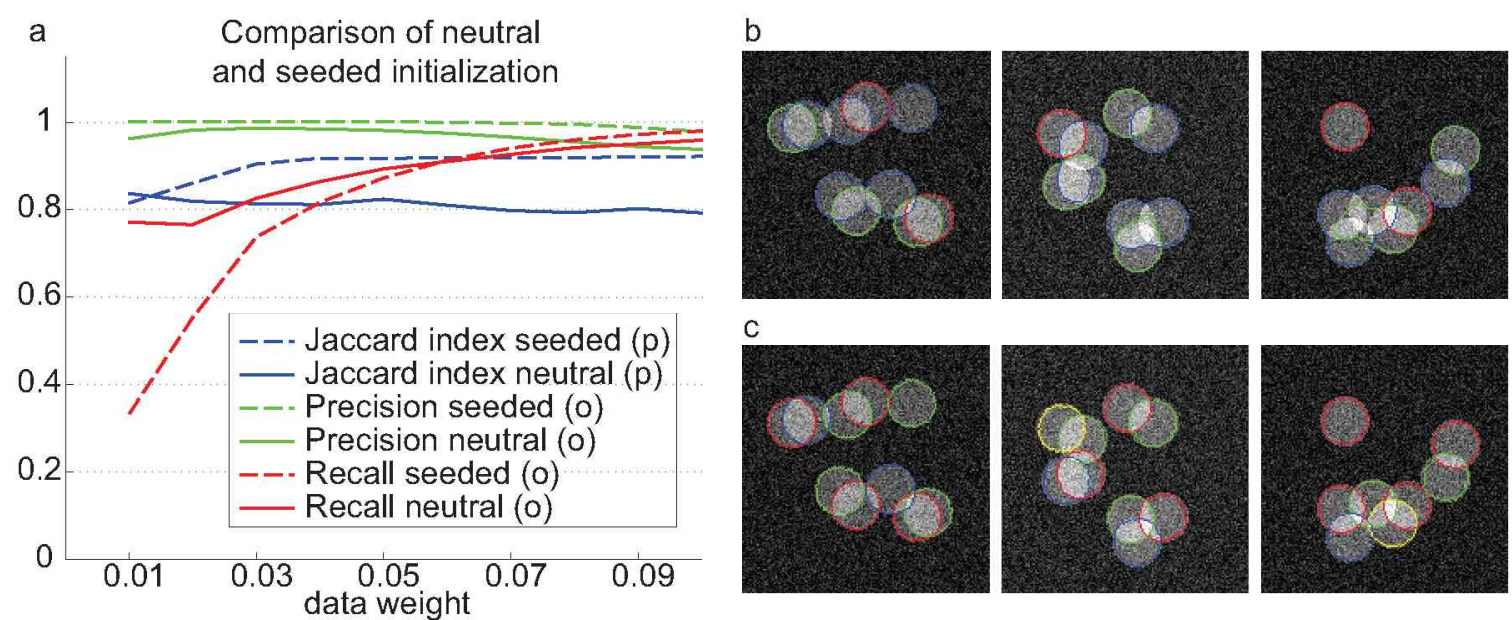

Figure 3.4: Synthetic results with different initialization methods. (a) Evaluation of segmentations with different initialization methods. 'Neutral' means the initial $\phi$ was set to a Gaussian white noise with mean $\lambda_{f} / \alpha_{f}$ and small variance (no initial objects are needed). 'Seeded' means that small circles inside the objects were used to initialize the phase field. (b) Segmentation results with neutral initialization using 3 layers. (c) Segmentation results with seeded initialization.

GOC model was set to the radius of the larger objects. Fig. $3.3 \mathrm{c}$ illustrates the results obtained using the model with the neutral initialization. The proposed model was able to select circles with the desired radius and correctly separate overlapping objects, while at the same time eliminated the circles with the smaller radius.

\subsubsection{Noise sensitivity}

It is common in fluorescent microscopy for images to have low contrast and low signalto-noise ratio (SNR) because of weak fluorescent staining or microscope properties. In order to show the robustness of the proposed method against noise, 50 synthetic images containing 15 circles with up to $20 \%$ overlap were generated. Images were distorted with levels of Gaussian white noise, resulting in SNRs of $20 \mathrm{~dB}, 15 \mathrm{~dB}, 10 \mathrm{~dB}, 5 \mathrm{~dB}, 0 \mathrm{~dB}$, and $-5 \mathrm{~dB}$. Note that $0 \mathrm{~dB}$ means that signal and noise have equal power, while $-5 \mathrm{~dB}$ means that the noise power is roughly three times the signal power. The proposed method was able to segment overlapping circles up to $0 \mathrm{~dB}$ with minimal error, with the first errors appearing at SNR $=-5 \mathrm{~dB}$ (Fig. 3.5). We have to note that the optimal data weight $\gamma_{d}$ depends on the level of the noise we added to the raw synthetic images. This dependency should come from the weighting role of the denominator in Eq. (5).

\subsubsection{Elongation}

The shapes of cell nuclei vary from circles to more elongated elliptical shapes, depending on various biological aspects, such as the origin of the cell and the phase of the cell cycle 
[76]. For example in our annotated image set, the mode (most frequent value) of the minor and major axes ratio of the nuclei was 1.32 , and the variance was 0.43 . The GOC shape model was originally designed to detect near circular shapes with possible slight perturbations [77]. We tested the ability of the proposed model to capture elongated objects (Fig. 3.6). Synthetic images were generated containing ellipses with $r_{\min }=10$ and $r_{\max }=\{11,12, \ldots, 25\}$. The allowed overlap area between two ellipsoids was $10 \%$. As expected, the segmentation becomes less perfect for larger $r_{\max }$. The proposed method is suited to most conventional cell nuclei types, but we do not recommend its use when the major/minor $\left(r_{\max } / r_{\min }\right)$ axis ratio exceeds 1.75 .

\subsubsection{Degree of overlap}

In order to test the ability of the model to separate overlapping objects accurately, a series of images was created with each image containing three overlapping circles of the same radius placed at the corners of an equilateral triangle. The distance between the centers of the circles was varied from 0 to 4 times the radius. Additional noise (SNR $=0 \mathrm{~dB})$ was added to the images. The segmentation results show that the accuracy is independent of the extent of the overlap, and that the method is capable of successfully segmenting circles (Fig. 3.7).

\subsubsection{Results on semi-real data}

To simulate real cell nuclei we used a framework, the SIMCEP, designed to generate and to evaluate algorithms for fluorescent microscopy images [78]. 50 images were generated by the framework, each containing 30 nuclei with a $50 \%$ maximal overlap allowed. The images were segmented by the combination of adaptive Otsu thresholding and the watershed method, and by the method proposed here (see Fig. 3.8). The proposed method outperformed the widely used one by $5-6 \%$ at pixel level accuracy and successfully identified cellular morphology on SIMCEP generated data.

The SIMCEP framework can simulate a wide range of artifacts of fluorescent microscopy. One of them can be clearly seen in Fig. 3.8: the cells can be out of focus. In the image it means blurred edges. Since our additive data model has an estimated parameter for the intensity of a single object, it affects the accuracy of segmentation on these blurred objects. Blurring causes that a narrow region around the edge of the ground truth object appear darker than the estimated single object intensity and therefore the segmentation does not capture the whole object, but a shrunk version of it. To compensate for this behaviour, we can slightly decrease the single object's intensity.

\subsubsection{Results on real data}

To test our model, twenty fluorescent microscopy images of different degrees of complexity, containing $\sim 2000$ cells in total, were chosen for quantitative evaluation. For evaluation purposes, ground truth segmentations were generated by manually annotating the images. The annotations were made by two experts using ImageJ ROI Manager 
with freehand selection. The image set consists of 20 images: 18 are different images with varying degrees of complexity; the other two images are $180^{\circ}$-rotated copies of two randomly chosen images from the initial 18.

We measured the segmentation accuracy on fluorescent microscopy images using precision/recall and the Jaccard index, and compared the results with those obtained from CellProfiler. In CellProfiler, we used a mixture of a Gaussian global threshold method and an intensity-based splitting of clumped objects with object diameters in the range of $25-35$ pixels. In the MLGOC model, the preferred radius was set empirically to 17 (Fig. 3.9), the mean radius of the manually annotated nuclei. To compare the MLGOC method to CellProfiler, we treated each image as different; therefore each of the 20 images has separate ground truth. In measuring self-consistency, we designated the original image as ground truth and the rotated version was compared to it, then vice-versa; the single metrics are the averages of the pairs of measures obtained this way. A similar method was used to measure inter-expert agreement. The experts' self-consistency measurements led to mean precision, recall, and Jaccard index values of $0.98,0.96$ and 0.78 , respectively. The values for inter-expert agreement were somewhat weaker: $0.93,0.93$ and 0.75 , respectively. As shown in Fig. 3.9, the proposed method outperforms the segmentation accuracy of CellProfiler, and also achieves a better Jaccard index, the value being as good as that arising from the agreement between different field experts. Separation ability is thus improved without losing detection accuracy.

\subsubsection{Performance}

The configuration used for the experiments was an Intel Core i7 CPU $2.93 \mathrm{GHz}$, with 6 GB RAM, running on Windows 7 64-bit operating system. The optimization on an image of size $400 \times 400$ using three phase field layers takes $\sim 70$ seconds if stopped after 500 iterations (with a mean stopping error of $\delta E / \delta \phi^{(k)}<10^{-7}$ ). The running time for each iteration is linear in the number of pixels and number of layers. 


\section{a $20 \mathrm{~dB}$}

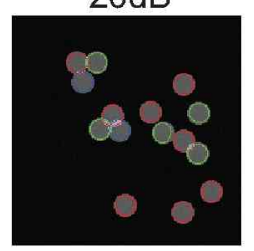

b
$15 \mathrm{~dB}$

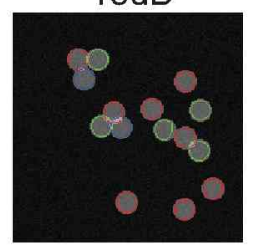

Precision and recall values for different noise levels

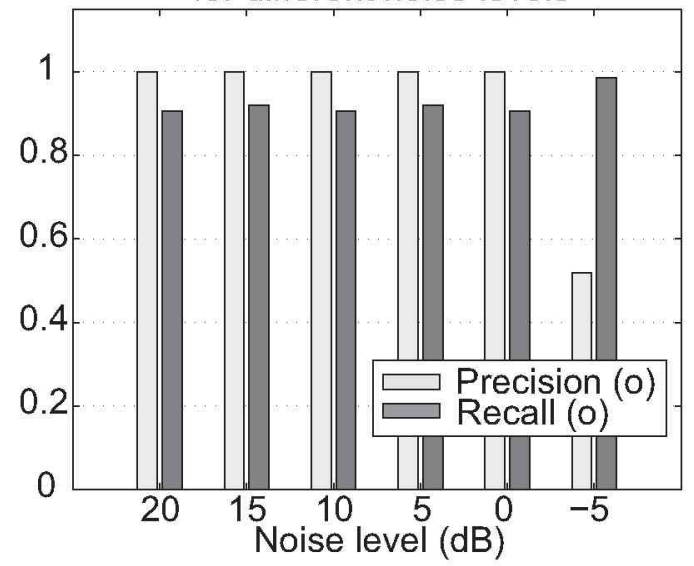

$5 \mathrm{~dB}$
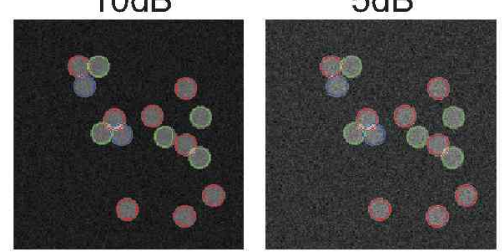

$\mathrm{c}$

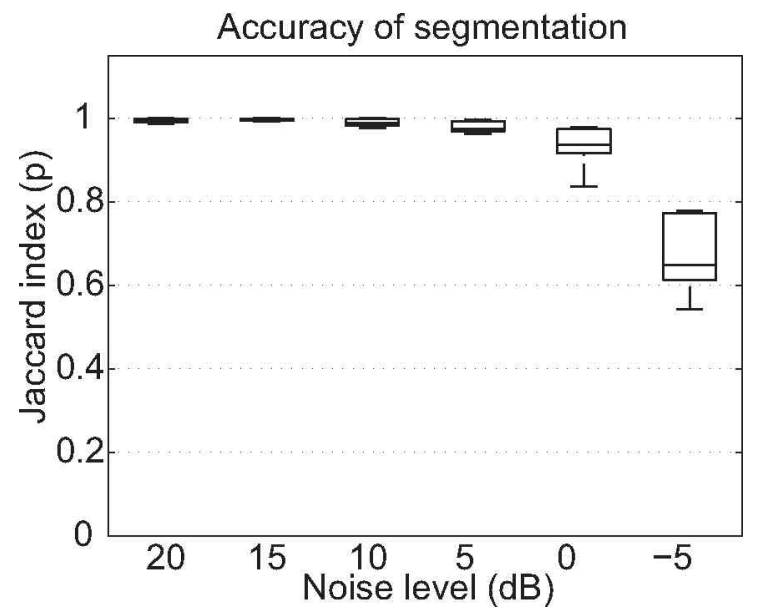

Figure 3.5: Synthetic results to test the robustness of the model to noise. (a) Synthetic image with overlapping circles and increasing levels of signal-to-noise ratio $(+20 \mathrm{~dB}$ to $-5 \mathrm{~dB}$ ). (b-c) Evaluation of the results of the proposed model. The segmentation results were evaluated on 50 test images per noise level. Note that different data term weights $\gamma_{d}$ were used for different noise levels. (b) Average precision and recall values of segmentation results for different signal-to-noise ratios. (c) Box and whisker plot of segmentation accuracy for different levels of signal-to-noise ratio. The bottom and top edges of the box indicate the first and third quartiles; the line inside the box indicates the median; the whiskers (lines protruding from the box) indicate the smallest and largest data points whose distance from the box is not greater than 1.5 times the interquartile range. 

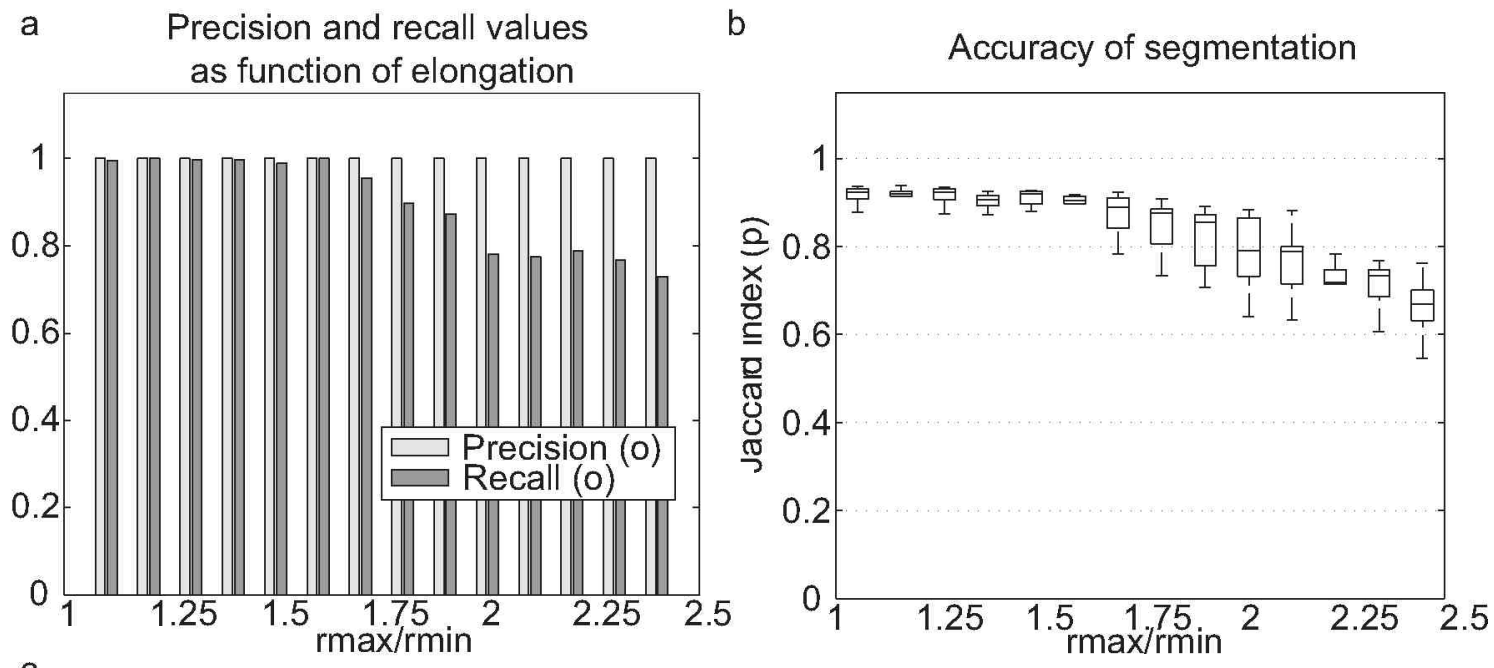

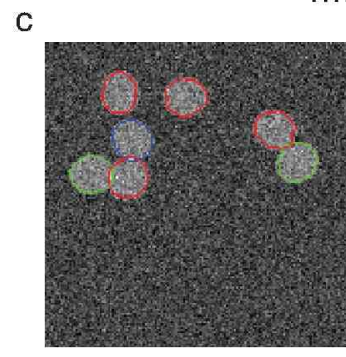

1.1

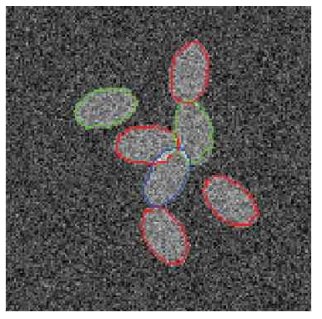

1.5

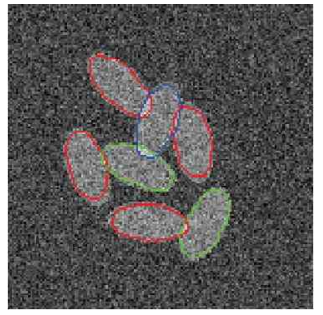

2.0

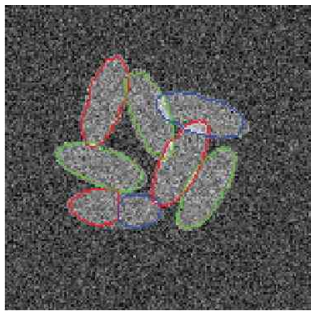

2.5

Figure 3.6: Robustness of the proposed method against elongation of circular objects. (a) Average precision and recall values for overlapping ellipses with increasing elongation. The values are computed from 100 test images per value $r_{\max } / r_{\min }=$ $\{1.1,1.2, \ldots, 2.5\}$. (b) Box and whisker plots representing accuracy of segmentation for increasingly elongated ellipses. The bottom and top edges of the box indicate the first and third quartiles; the line inside the box indicates the median; the whiskers (lines protruding from the box) indicate the smallest and largest data points whose distance from the box is not greater than 1.5 times the interquartile range. (c) Examples of segmentations of synthetic images containing ellipses of increasing elongation. 
a

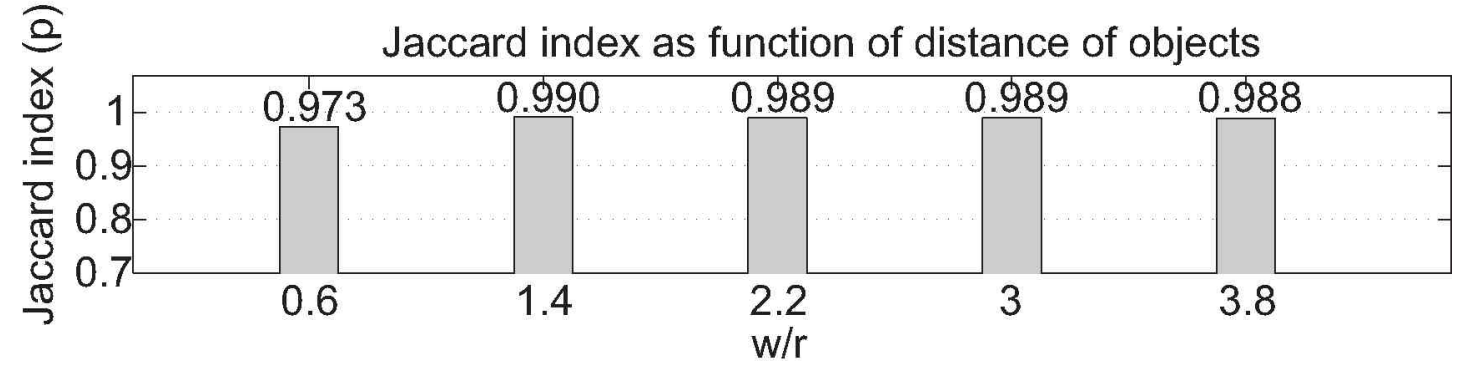

b
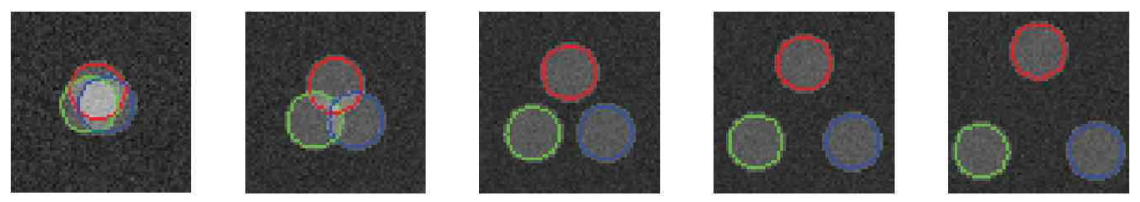

Figure 3.7: Separation ability of the proposed method. (a) Segmentation accuracy on synthetic images containing circles with increasing degrees of overlap. Numbers on the $\mathrm{X}$-axis show the $w / r$ ratio, where $w$ is the distance between circles' centers and $r$ is radius of the circles. Values of $w / r<2$ mean that objects are overlapping. (b) Examples of segmentations of synthetic images containing circles with different degrees of overlap. 
a Precision, recall and accuracy of segmentations

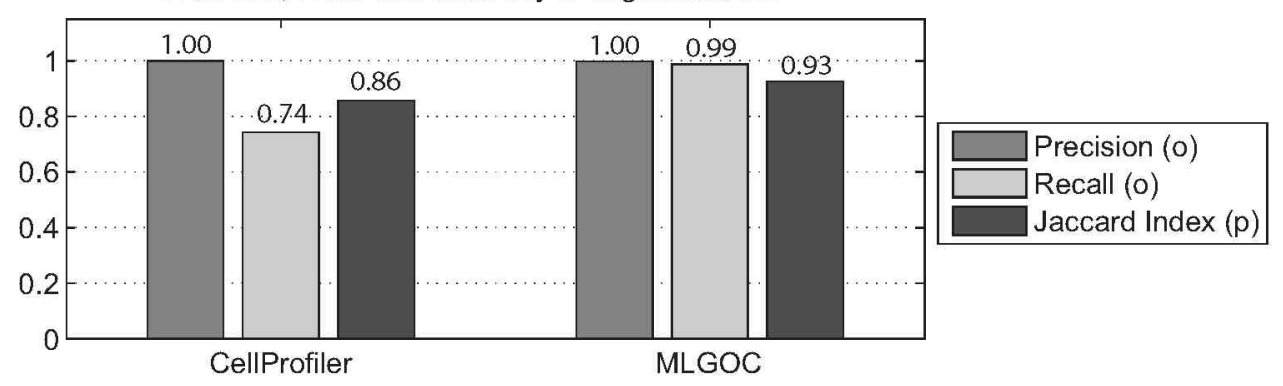

$\mathrm{b}$ Original

CellProfiler

MLGOC
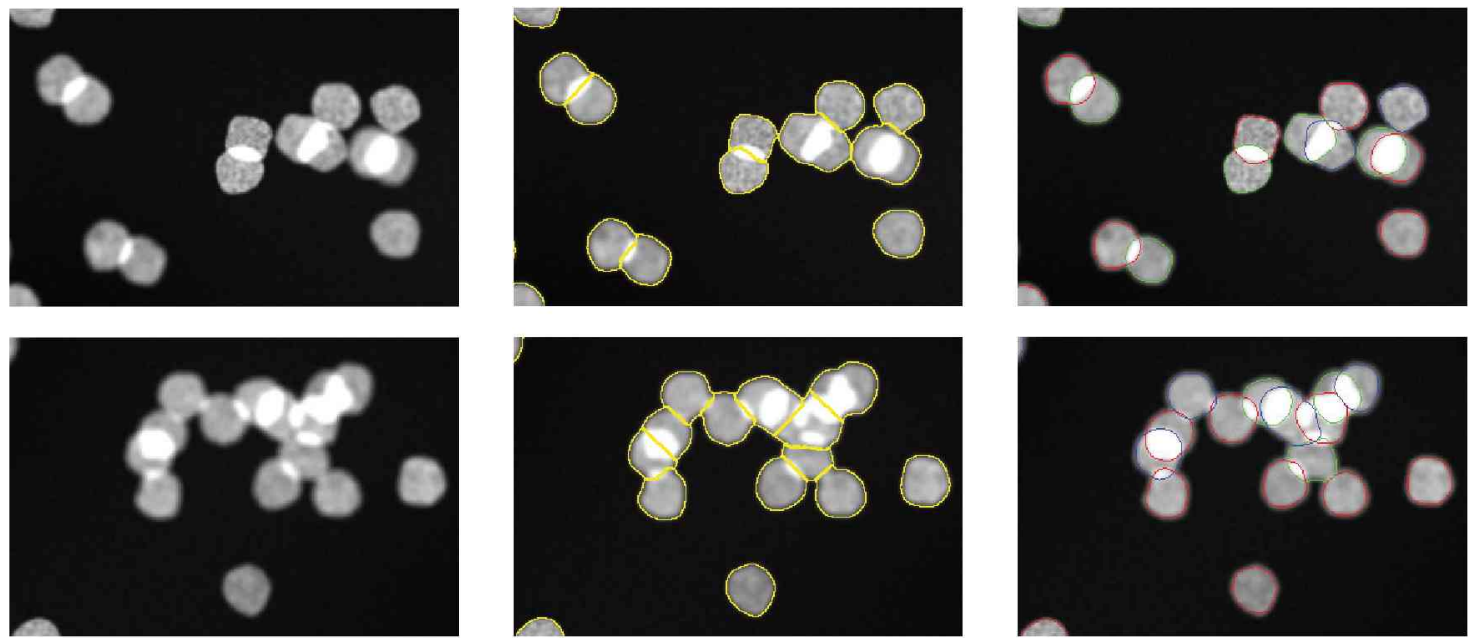

Figure 3.8: Segmentation results on SIMCEP (framework for generating artificial fluorescent microscopy images) data set. (a) Object detection and segmentation accuracy of the combination of Otsu thresholding and the watershed based object declumping, and the proposed MLGOC method. (b) Left column: images containing overlapping artificial nuclei with possible distortion caused by the microscope applied; middle column: segmentations with the Otsu-watershed combination; right column: segmentations with the proposed method. 
a Precision, recall and accuracy of segmentations

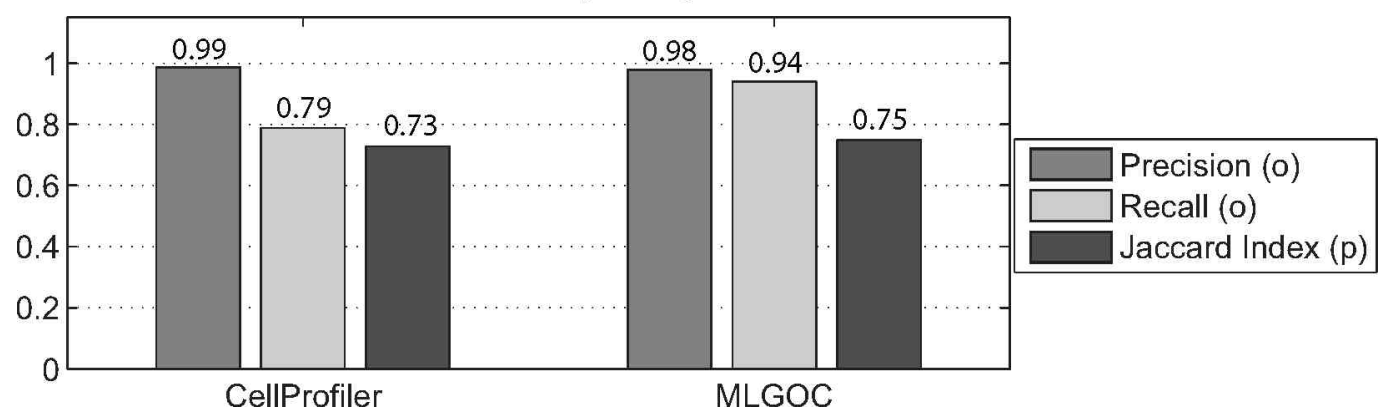

b

Original
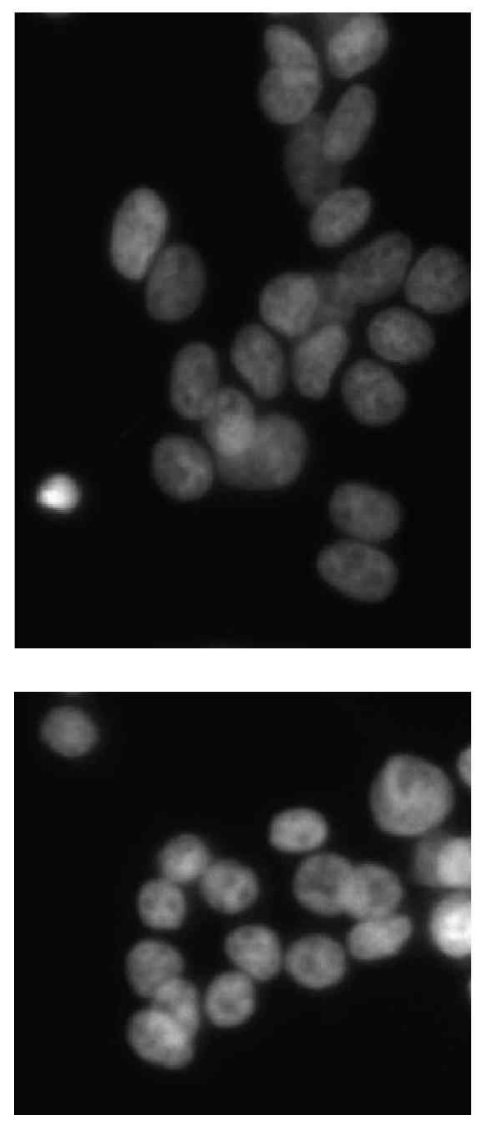

CellProfiler
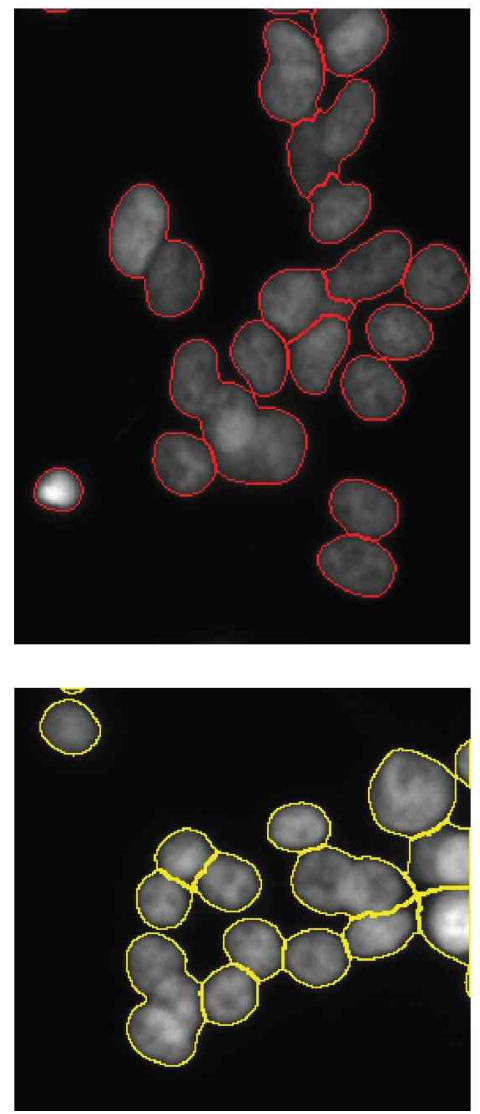

MLGOC
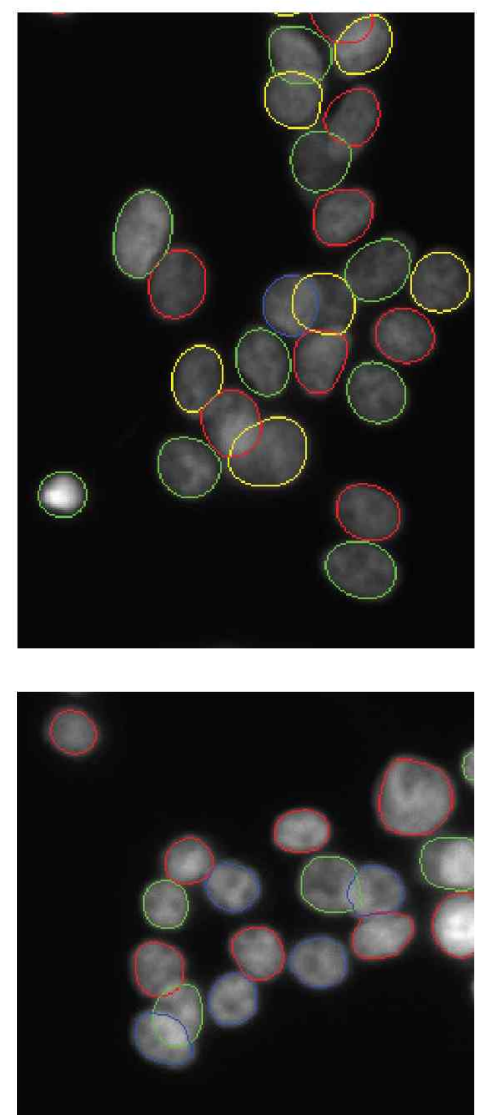

Figure 3.9: Segmentation results on real fluorescent microscopy images. (a) Object detection and segmentation accuracy of CellProfiler and the MLGOC method. (b) Left column: original images of prostate cancer cells containing overlapping nuclei; middle column; segmentation results obtained with the CellProfiler software; right column: results with the MLGOC method 


\section{Chapter 4}

\section{Selective active contours}

This chapter is about the construction of 'selective active contours'. The main concept is to describe a wide family of shapes such as circles, ellipses or plasma-like shapes by simple descriptors such as area or/and perimeter, which can be effectively calculated by line integrals over the contour.

Active contours, also called snakes [79], are effective and widely used tools in image processing and computer vision to locate object boundaries in images or in scenes. Active contours are curves defined within an image domain that can move under the influence of internal forces, coming from the curve itself, and external forces, coming from image data. The main idea of these dynamic curves is to evolve a surface under constraints defined by a priori knowledge, and to drive it towards features of interest in an image by the image data derived forces.

The classical active contour model by Kass et al. [79] includes terms that control the smoothness of the curve, which terms are acting as very simple shape regulators. The geometric active contours involve the advantages of the level set method over snakes such as they are able to handle topological changes occurring during the evolution of the curve, and we can make the calculations on a discrete grid by finite-difference approximations for continuous derivatives (see Section 1).

Here we give a novel geometric active contour representation of commonly used shape descriptors. The simplest shape property, the size of an object can be determined by its area or perimeter. The perimeter can be approximated by the sum of line segments of the contour, and the area can be approximated by the shoelace formula (which can also be considered as a special case of Green's theorem on closed curves), and therefore both require operations proportional to the length of the object boundary. From among the huge number of shape descriptors we can select a few ones which cost linear number of operations, e.g. circularity or some of the moments. In Section 4.1.3 we define some very simple energy functionals as internal forces of curves which functionals can model contours of specific shapes such as ellipsoids or plasma-like shapes. To keep our optimization numerically and topologically stable we build smoothness terms into our shape functional.

To complete the classical active contour framework, in Section 4.1.7 we give a region based image model as the external part of the energy. Region-based image mod- 
els $[27,80,81]$ have advantages over gradient- or edge-based data terms: a) they are proved to be very efficient in dealing with noisy images; b) they are less sensitive to the initialization of the contours. Our data model is moderately scalable and shows anisotropic behaviour.

\subsection{Selective active contours}

This section introduces a new family of curves that can describe shapes of plasma-like or elliptical shapes of various degree of elongation without including any template shapes and guided by computationally inexpensive line integral derived quantities.

\subsubsection{Notations}

We introduce the notations and mathematical tools used throughout the rest of the chapter. Point set of the image plane, i.e. the image domain, is denoted by $\Omega$, parametrized by Cartesian image coordinates $x$ and $y,[x, y] \in \Omega \subset \mathbb{R}^{2}$. Contours are closed planar curves, given with vector valued function of the curve parameter $t$ such that: $\Omega \supset r(t)=x(t) \mathbf{i}+y(t) \mathbf{j}$, where $\mathbf{i}, \mathbf{j}$ are the standard basis vectors and $\mathbf{k} \doteq \mathbf{i} \times \mathbf{j}$ is the unit normal vector of the image plane. The unit tangent vector of the contour is $\mathbf{t} \doteq \frac{\dot{\mathbf{r}}}{|\dot{\mathbf{r}}|}, \dot{\mathbf{r}}=\frac{d \mathbf{r}}{d t}$. The unit normal vector of the contour $\mathbf{n}$ is defined by the plane normal $\mathbf{k}$ as $\mathbf{n}=\mathbf{k} \times \mathbf{t}$. Note that assuming $\mathbf{i}, \mathbf{j}, \mathbf{k}$ is right-handed and the contours parametrized counter-clockwise have normal vectors pointing inwards. Arclength of the curve is denoted by $s$. The coordinate differentials and differential operators are related with $d s=|\dot{\mathbf{r}}| d t$ and $\frac{d}{d s}=\frac{1}{\mid \dot{\mathbf{r}}} \frac{d}{d t}$, respectively. Let $\mathbf{u}, \mathbf{v}$ be two arbitrary vectors of the image plane, the following notations are used: a) scalar product $\mathbf{u} \cdot \mathbf{v}$; b) cross product $\mathbf{u} \times \mathbf{v}$; c) direct (dyadic) product $\mathbf{u v}$. The following operations are defined between the dyad $\mathbf{u v}$ and vector $\mathbf{w}: \mathbf{u v} \cdot \mathbf{w} \equiv(\mathbf{v} \cdot \mathbf{w}) \mathbf{u}, \mathbf{w} \cdot \mathbf{u v} \equiv(\mathbf{u} \cdot \mathbf{w}) \mathbf{v}$ (i.e. the transpose of $\mathbf{u v}$ is $\mathbf{v u}), \mathbf{w} \times \mathbf{u v} \equiv(\mathbf{w} \times \mathbf{u}) \mathbf{v}$ and frequently used in the following models. The signed curvature of the contour is denoted by $\kappa$, defined using the plane normal as $\frac{\ddot{\mathbf{r}} \cdot \mathbf{n}}{|\dot{\mathbf{r}}|^{2}}$. The gradient of an arbitrary quantity $\mathbf{X}$ is denoted by $\nabla \mathbf{X}$; given any orthonormal basis $\mathbf{e}_{i}$, $i=1,2$ and coordinates $x_{i}$ it is defined as $\nabla \mathbf{X}=\sum_{i=1,2} \mathrm{e}_{\mathbf{i}} \frac{\partial \mathbf{X}}{\partial x_{i}}$ (we use either the standard basis $\mathbf{e}_{1}=\mathbf{i}, \mathbf{e}_{2}=\mathbf{j}$ or the local basis along the contour $\mathbf{e}_{1}=\mathbf{t}, \mathbf{e}_{2}=\mathbf{n}$ ); if $\mathbf{X}$ is a vector then its gradient is a second order tensor. The identity tensor $\mathbf{I}$ is a second order symmetric tensor with identities $\mathbf{I} \cdot \mathbf{w}=\mathbf{w} \cdot \mathbf{I}=\mathbf{w}$, its decomposition in the standard basis is $\mathbf{I}=\mathbf{i} \mathbf{i}+\mathbf{j} \mathbf{j}$, whilst in the local basis it is $\mathbf{I}=\mathbf{t t}+\mathbf{n n}$.

\subsubsection{Size priors}

We can give very simple 'measurements' over the contour such as perimeter of the boundary or the area of the bounded region, and therefore we can define energy functionals which have optimum at preferred size of the represented object. To promote a given perimeter we can give the error functional 


$$
\mathcal{E}_{S-L}(\dot{\mathbf{r}})=f_{S}\left(\oint d s-L_{0}\right)
$$

where $L_{0}$ is the preferred length of the object boundary, $d s=|\dot{\mathbf{r}}| d t$ and $f_{S}$ is the function having inflection at zero; a simple, practical choice with horizontal tangent line at the inflection point can be $f_{S}(x)=\frac{1}{3} x^{3}$. Similarly, characterizing objects with preferred internal area, the error functional is

$$
\mathcal{E}_{S-A}(\mathbf{r}, \dot{\mathbf{r}})=f_{S}\left(\oint d A-A_{0}\right)
$$

where $A_{0}$ is the preferred internal area of the object, $d A=\frac{1}{2} \mathbf{k} \cdot(\mathbf{r} \times \dot{\mathbf{r}}) d t$ is the Euclidean area element, $\mathbf{k}$ is the normal of the plane of the (planar) curve $\mathbf{r}(t)$. Note that the enclosed area can be calculated as line integral over the curve points. Function is selected to be 'coherent' with the shape priors either $f_{S}(x)=\frac{x^{3}}{3}$ for 'ellipse' prior or $f_{S}(x)=\frac{\operatorname{sign}(x) x^{2}}{2}$ for 'plasma' prior (see Fig. 4.1 top row). For the tests we used the latter prior (Eq. (4.2)). Note that using these functions, the inflection point can be easily extended to 'inflection range' to select objects with sizes falling between two threshold limit values.

\subsubsection{Shape priors}

Further selectivity can be achieved by adding shape prior to the functional. Various features have been designed to represent shapes that are based either on information about shape boundary or on boundary plus interior region. Any contour or region based global shape descriptor can be incorporated into energy minimization methods [82]. Here we present two contour based priors inflicting the least possible computation load. The ratio of the square of the object's perimeter and the enclosed area $q_{C}=\frac{(\oint d s)^{2}}{\oint d A}$ is being used as the simplest global shape descriptor to distinguish objects with elongated parts from compact ones. For instance, a circle of a given radius $r_{0}$ has the lowest $q_{C}$ value $4 \pi \approx 12.56$ for fixed preferred area $A_{0}=\pi \times r_{0}{ }^{2}$. The simplest functional penalizes the deviation from the ratio $q_{C}$ is defined by the function $f_{S H}$ as

$$
\mathcal{E}_{S H}(\mathbf{r}, \dot{\mathbf{r}})=f_{S H}\left(\oint d A-\frac{1}{q_{C}}(\oint d s)^{2}\right)
$$

with minimum at zero. The minimizer is chosen to be $f_{S H}(x)=\frac{1}{2} x^{2}$. The central moments of the enclosed area or contour itself are often used as well. The normalized second central moment of the contour $\frac{1}{q_{M}}=\frac{M_{2}}{\oint d A \oint d s}$ (where $M_{2}=\oint\left|\mathbf{r}_{0 t}\right|^{2} d s, \mathbf{r}_{0 t}=\mathbf{r}-\mathbf{r}_{0}$ and $\mathbf{r}_{0}$ is the center of gravity of the contour: $\mathbf{r}_{0}=\frac{\oint \mathbf{r} d s}{\oint d s}$ ) has strong shape discrimination effect and can also be calculated along the contour with line integral. The functional penalizing the deviation from a preferred normalized second moment is: 

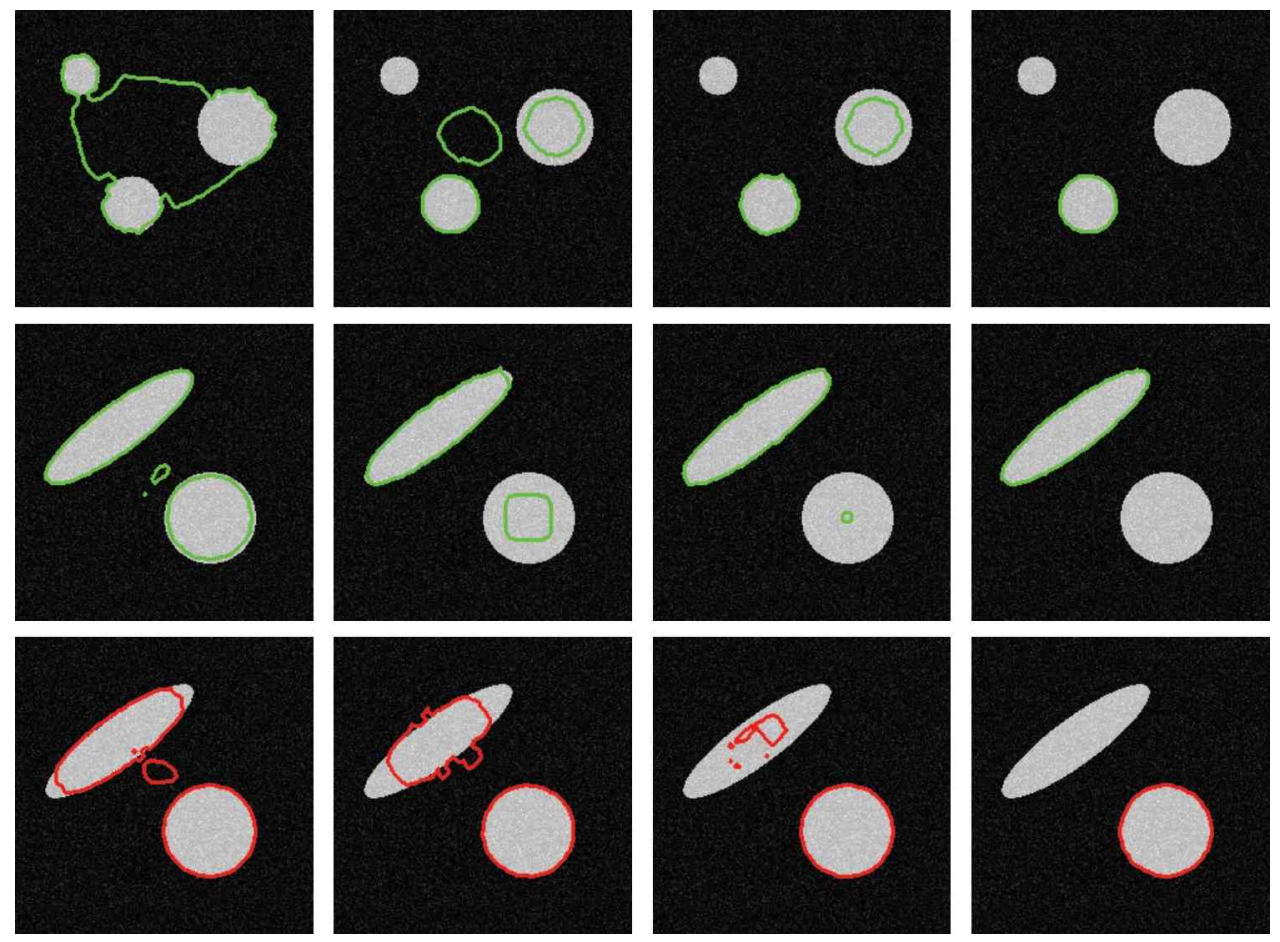

Figure 4.1: Contour evolution with different geometric priors. Top row: contour evolution using size prior only; the area is set to the size of the object in the middle. Middle and bottom rows: contour evolution extended with ellipse shape prior (middle row) and circle prior (bottom row). Around the inflection, the size prior has no significant effect and the shape prior dominates. If shape and data priors contradict, the contour gradually loses its size as trying to enforce the preferred shape. Finally, the contour size falls below the size determined by the inflection value causing its disappearance.

$$
\mathcal{E}_{S H}(\mathbf{r}, \dot{\mathbf{r}})=f_{S H}\left(\oint d A \oint d s-q_{M} M_{2}\right) .
$$

Using Eq. (4.4) at its minimum, the quadratic function $f_{S H}(x)=\frac{1}{2} x^{2}$ is used again (see Fig. 4.1 middle and bottom rows). Similarly to the size prior, the minimum point can be extended to minimum range to select minimizer shapes falling between threshold limit values.

To get a stable solution, the combination of the size and shape priors require a smoothness term to be added. Adequate smoothness terms are discussed below in Section 4.1.4.

A set of contours satisfies both priors, but there is a notable difference between these solutions. The experimental analysis shows that the prior based on the second moment of the contour (Eq. (4.4)) strongly favors ellipse-like structures as stable solutions. On the contrary, the minimizing contour set of the perimeter-area ratio functional (Eq. (4.3)) has no such preference, all its solutions are coequal in the sense of stability (see Fig. 4.2). Other shape priors can utilize the line integral of an appropriate function 
of the curvature. We do not investigate priors based on this quantity, however the necessary Euler-Lagrange equation is provided (see Eq. (4.5)). The derivation of the equations can be found in Appendix B.

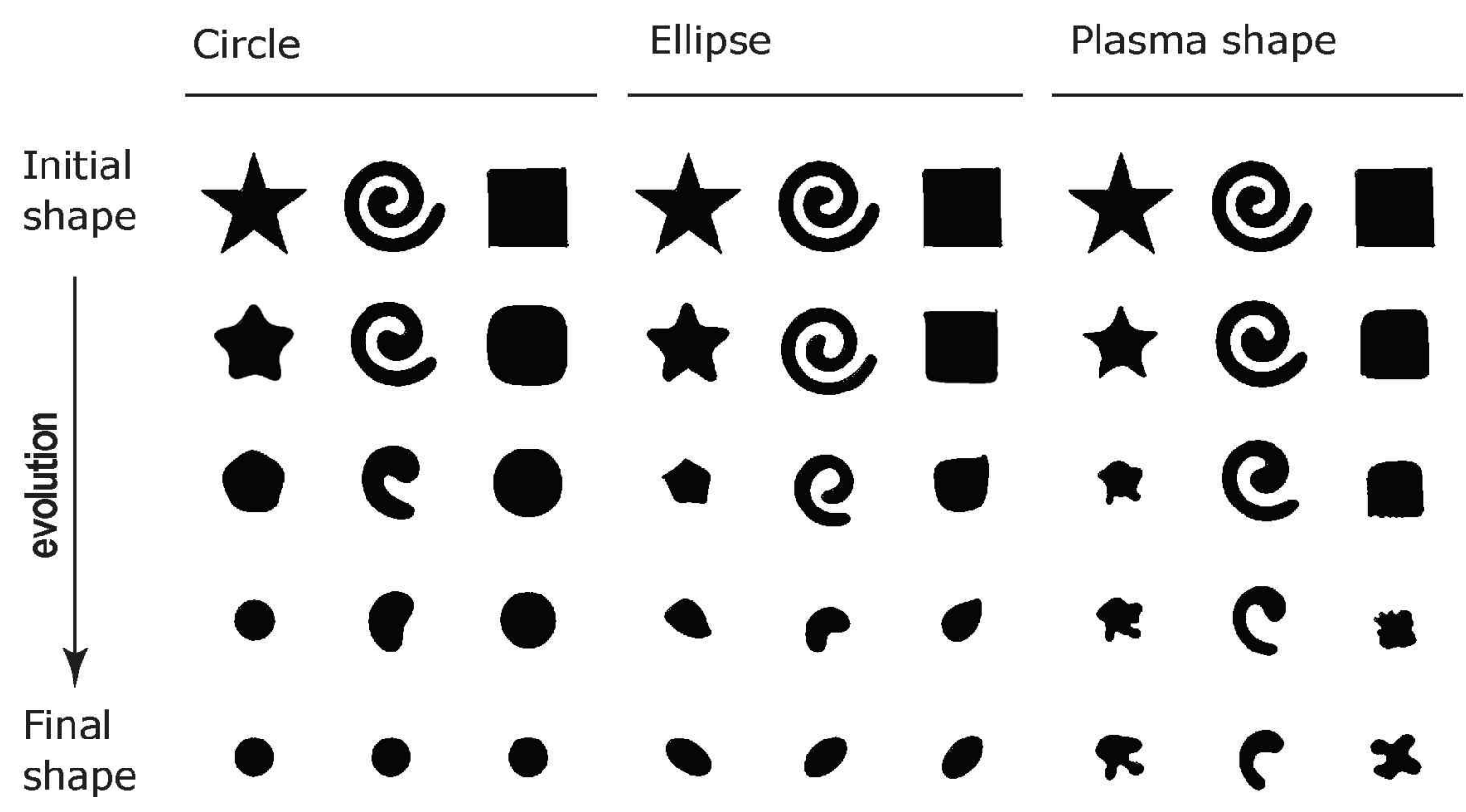

Figure 4.2: Experimental results showing initial, intermediate, and final state of the contour evolution using circle (i.e. using ellipse shape prior with shape parameter set to $4 \pi$ ), ellipse and plasma shape priors. For this test same sizes were set for all shapes and the size prior was chosen to be minimizer ${ }^{2}$ (i.e. $f_{S}=x^{2} / 2$ in Eq. (4.2)).

\subsubsection{Smoothness terms}

Without appropriate smoothness term the combination of shape and size priors could display unstable behaviour or slow convergence towards the preferred shape. For the second moment based shape prior, which favours ellipse-like curves, the use of the simplest arclength minimizer is feasible ${ }^{3}$, but for the 'plasma' shapes it is not. The simple signed curvature: $\kappa=\frac{\ddot{\mathbf{r}} \cdot \mathbf{n}}{|\dot{\mathbf{r}}|^{2}}, \mathbf{n}=\mathbf{k} \times \frac{\dot{\mathbf{r}}}{|\dot{\mathbf{r}}|}$ cannot be used in geometric contour context, because its integral over arbitrary closed (planar) curve ${ }^{4}$ is always $2 \pi$. We use $\kappa^{2}$ instead, which has well defined meaning originated from the mechanics of the flexible rods: the bending energy of the curve called 'Euler elastica' [83]. The smoothness based on this quantity is:

\footnotetext{
${ }^{2} \mathrm{~A}$ function chosen to have an inflection point at zero without any data term forces the objects to disappear.

${ }^{3}$ It may contribute to the ellipse formation as well.

${ }^{4}$ with turning number 1
} 


$$
\mathcal{E}_{\mathcal{S M}-\mathcal{E E}}(\dot{\mathbf{r}}, \ddot{\mathbf{r}})=\frac{1}{2} \oint \kappa^{2} d s
$$

This smoothness term has minimal interference with the other terms, however for contours with small size, it predisposes to display over-smoothing effect, preferring circles over elongated objects. To overcome this problem, one can use the dimensionless version of this kind (Eq. (4.5)) instead:

$$
\mathcal{E}_{S \mathcal{M}}(\dot{\mathbf{r}}, \ddot{\mathbf{r}})=\oint d s \oint \kappa^{2} d s
$$

its influence is essentially confined to guaranteeing the stability of the contour.

\subsubsection{Composite functional}

In the following sections we address some practical questions such as the suitable data term selection, the form of the prior function and the scale invariance which inherently occurs in any composite functionals. Finally, the associated Euler-Lagrange equations are presented. We get the composite functional as the complete segmentation framework by the joint effect of the geometric prior and the data term. In this type of compositions of energies the first main task to do is to find the fitting contribution of these two major components to the model, i.e. to fine-tune their weights in the composite energy functional. We often face the situation that the geometric prior and the energy coming from the image data act competitively, but after finding a proper weighting of them a satisfactory solution of the problem can be achieved.

\subsubsection{Energy normalization: dimensionless quantities}

The use of integral terms with different dimensions would require different weights between the terms in both the internal and external forces depending on the size of the objects. From a theoretical point of view, using dimensionless terms in the composite functional would be the most appropriate solution, however this can rarely be achieved without compromising the overall performance of the methods. Fortunately in most cases, a simpler approach (normalizing by a function of the targeted area and/or length) provides acceptable result. Below we discuss the measurements to address this problem in the composite functional we use for the selective active contours. In fact, all tests were run using the same weights.

The three component functionals, the size, the shape and the smoothness, are combined such that their internal weights are fixed once and for all. The dimensionless versions, the relative size and the normalized shape, are combined into a subgroup with a suitable smoothness as 


$$
\begin{aligned}
\mathcal{S}_{\mathcal{S H}-\mathcal{P}}(\mathbf{r}, \dot{\mathbf{r}}, \ddot{\mathbf{r}}) & =\frac{\operatorname{sign}\left(\oint d A-A_{0}\right)}{2 A_{0}^{2}}\left(\oint d A-A_{0}\right)^{2} \\
& +\frac{\lambda}{2 A_{0}^{2}}\left(\oint d A-\frac{1}{q}(\oint d s)^{2}\right)^{2} \\
& +\frac{\mu}{2} \oint d s \oint \kappa^{2} d s
\end{aligned}
$$

for plasma shapes, and

$$
\begin{aligned}
\mathcal{S}_{\mathcal{S H}-\mathcal{E}}(\mathbf{r}, \dot{\mathbf{r}}) & =\frac{1}{3 A_{0}^{3}}\left(\oint d A-A_{0}\right)^{3} \\
& +\frac{\lambda}{2\left(A_{0} L_{0}\right)^{2}}\left(\oint d A \oint d s-q \oint\left|\mathbf{r}_{0 t}\right|^{2} d s\right)^{2} \\
& +\frac{\mu}{L_{0}} \oint d s
\end{aligned}
$$

for the ellipse-like shapes. The parameter $q=\frac{\oint d A \oint d s}{\oint\left|\mathbf{r}-\mathbf{r}_{0}\right|^{2} d s}$ for ellipses with predefined minor/major axis ratio $z=\frac{b}{a}, z \geq 0$ can be given by a function defined with the length of ellipse $\left(L_{0}\right)$ expressed by the integral formula using $\oint d s=\int_{0}^{2 \pi}|\dot{\mathbf{r}}| d t$ with $\mathbf{r}_{0}=0$ and $\mathbf{r}(t)=a \cos t+b \sin t$ as ${ }^{5}$ :

$$
q=z \frac{\pi \oint \sqrt{\sin ^{2} t+z^{2} \cos ^{2} t} d t}{\oint\left(\cos ^{2} t+z^{2} \sin ^{2} t\right) \sqrt{\sin ^{2} t+z^{2} \cos ^{2} t} d t}
$$

This function has the maximum $\pi$ at $z=1$ (circle shape) and possesses the property $q(z)=q\left(\frac{1}{z}\right)$.

\subsubsection{Region based local data term}

In principle, the use of any appropriately parameterized data term is feasible in this framework. Region based data terms are preferred over point-wise ones because of their robustness against noise. The simplest Chan and Vese data term [27] is not applicable here because it has an undesired persistence of inflation force if the contour is inside the object, which force is an effect of the global nature of this data term. This effect prevents the contour from falling through the inflection point in the case of the simplest cubic expression of the size prior $\left(\oint d A-A_{0}\right)^{3}$. Localized region data terms like in $[80,81]$ provide a solution for this problem, but the approach they use is not compatible with

\footnotetext{
${ }^{5}$ This is a hypergeometric function. There is no closed form formula expressible with elementary functions for the ellipse perimeter.
} 
ours $^{6}$. Here we propose a geometric local region data term $\mathcal{D}$ applicable for a similar purpose:

$$
\mathcal{D}(\mathbf{r}, \dot{\mathbf{r}})=\oint \Phi(\mathbf{r}, \mathbf{n})|\dot{\mathbf{r}}| d t
$$

Below we define the Lagrangian $\Phi$ and specify its derivatives suitable for image segmentation. Let the position vector $\mathrm{p}$ given as a sum of two vectors: the origin of the Frenet frame $\mathbf{r}$ and the local vector $\xi \mathbf{t}+\eta \mathbf{n}$ :

$$
\begin{aligned}
\mathbf{p} & =\mathbf{r}+\xi \mathbf{t}+\eta \mathbf{n} \\
& =\mathbf{r}-\xi(\mathbf{k} \times \mathbf{n})+\eta \mathbf{n} .
\end{aligned}
$$

Now we define two local regions along the contour given by the Cartesian products of the local coordinates (see Fig. 4.3): $\mathfrak{R}^{+}: \xi \in[-p, p] \times \eta \in[0, q], \mathfrak{R}^{-}: \xi \in[-p, p] \times \eta \in$ $[-q, 0]$, and the corresponding intensity sum functions $\phi^{+}: \mathfrak{R}^{+} \mapsto[0,2 p q], \phi^{-}: \mathfrak{R}^{-} \mapsto$ $[0,2 p q]$ (here we assumed normalized image intensity function: $0 \leq I \leq 1$ ). The segmentation problem is then represented by the intensity mean difference function $\Phi=\frac{1}{2 p q}\left(\phi^{+}-\phi^{-}\right)$expressed with local integrals

$$
\Phi(\mathbf{r}, \mathbf{n})=\frac{1}{\|\mathfrak{R}\|}\left(\iint_{\mathfrak{R}^{+}} I(\mathbf{p}) d A-\iint_{\mathfrak{R}^{-}} I(\mathbf{p}) d A\right),
$$

where $d A=d \xi d \eta$, and $\|\Re\|=2 p q$. Note that the functional Eq. (4.11) has a minimum if region $\mathfrak{R}^{+}$has a lower mean intensity than of $\mathfrak{R}^{-}$(for the opposite case the signs of $\phi^{+}$and $\phi^{-}$have to be reversed). Also, the boundaries of the local integrals are independent of $\mathbf{r}$ and $\mathbf{n}$ hence parametric w.r.t. these quantities.

This local region data term is moderately scalable and shows anisotropic behaviour (Fig. 4.4). See Appendix B for more details. Note that the explicit use of the local coordinate system by the Lagrangian in machine vision was first proposed in the work of Faugeras and Keriven [84] for 3D stereo reconstruction purpose. The same principle is used here in 2D for image segmentation. A similar approach, using simplified EulerLagrange equation (its first order approximation), can be found in [85]. Here we use the complete equations (derivation can be found in Appendix B). The local region data term keeps the robustness against noise while it does not have inflation force inside the objects.

The local region data term requires an additional term to force the initial contour to shrink because on homogenous image data this functional is neutral. Simplest area minimizer is used in this position and the selective object segmentation functional has its final form as:

$$
\mathcal{F}=\bar{f}\left(\int d A\right)+\frac{\alpha}{L_{0}} \mathcal{D}+\beta f(\mathcal{E})
$$

\footnotetext{
${ }^{6}$ These functionals are defined on the vector space of the two-dimensional level set functions.
} 


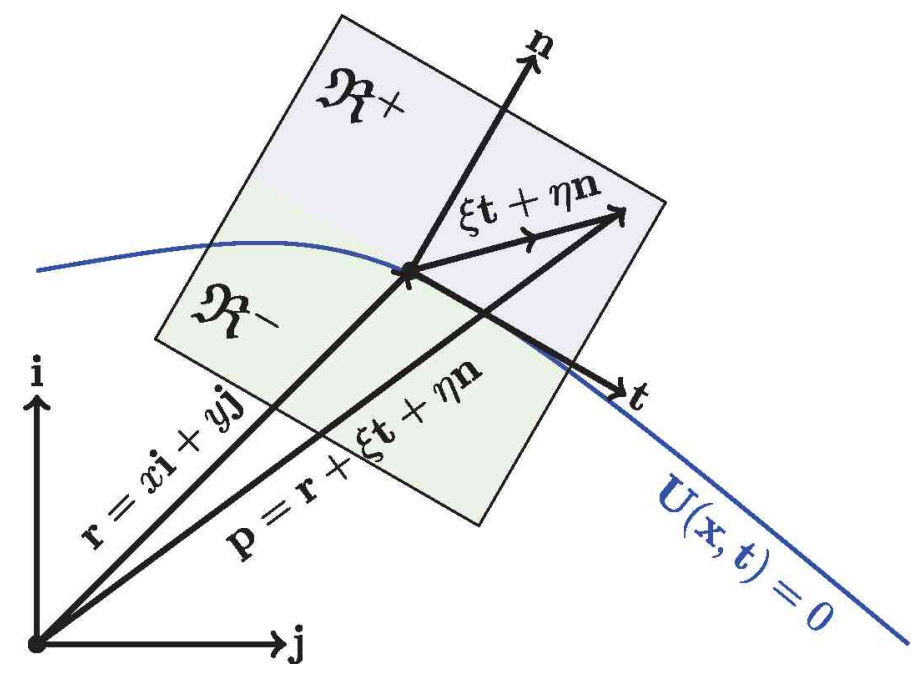

Figure 4.3: The local coordinate system for region based data model. Its abscissa is aligned to the tangent vector of the contour.
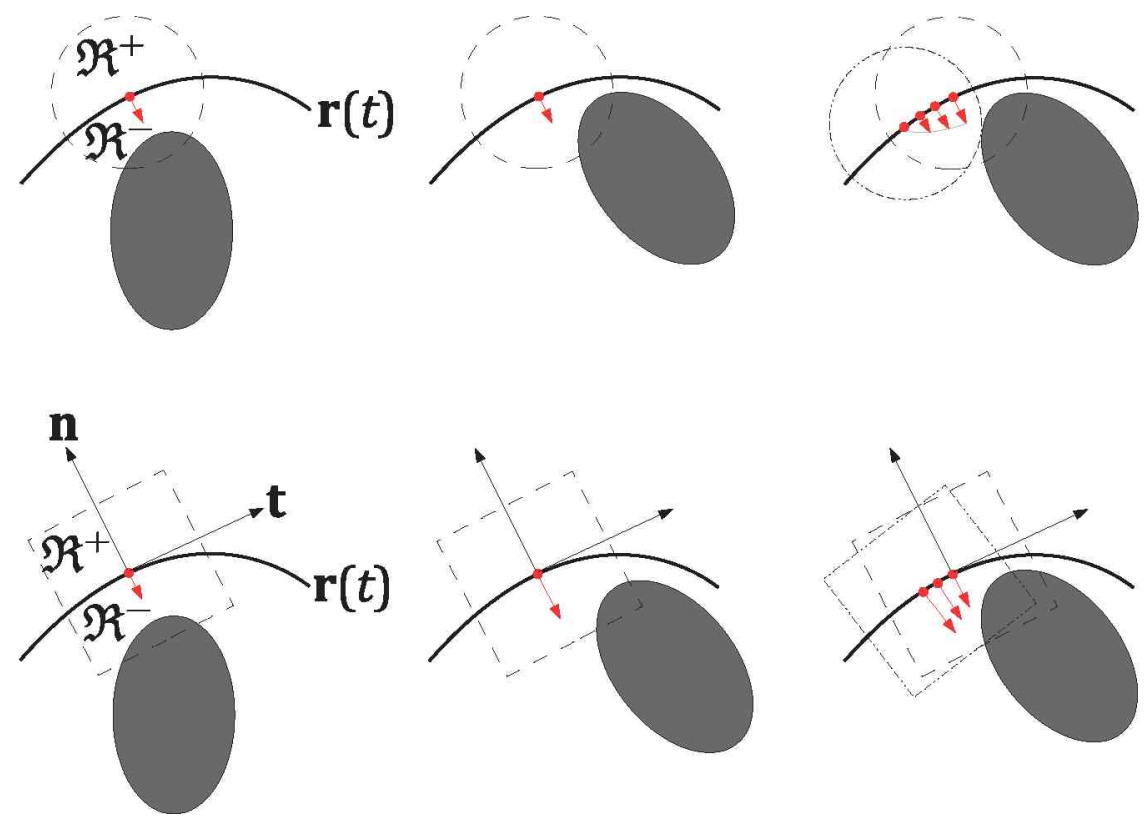

Figure 4.4: Comparison of isotropic (top row) and anisotropic (bottom row) local region data terms. The speed of the contour points does not depend on the position of the object to be captured in the isotropic case, whilst it is dependent in the anisotropic case (left and center columns). The speed distribution of a set of neighbouring points is shown in the right column.

where $\mathcal{E}$ represents either $\mathcal{S}_{\mathcal{S H}-\mathcal{P}}$ or $\mathcal{S}_{\mathcal{S H}-\mathcal{E}}$. Note that the first term is not required to be scale corrected in practice. The function $f$ is constant if it is significantly higher than the targeted size (for example two to three times of the targeted size), and it is the 
identity function below this threshold (i.e. it does not work above the threshold, and outputs $\beta \mathcal{E}$ below it). $\bar{f}$ is the complementary of $f$ in sense that only one of them has contribution to the energy for a fixed object area, a given threshold separates their active fold. Using these functions during the evolution, the contour acts as a presegmentation method above the threshold, then the shape and size priors get dominant. Note that from a theoretical point of view, $f$ and $\bar{f}$ should have smooth (continuously derivable) transition around the threshold. The above simplification causes sharp switching during the evolution between the area minimizer $f$, and shape and size prior function $\bar{f}$, but performs well for a wide variety of practical problems.

\subsubsection{Euler-Lagrange equations of selective contours}

The associated Euler-Lagrange equations for the component functionals in Eq. (4.12) have the common form $|\dot{\mathbf{r}}| Q \mathbf{n}=0$ as usual in the case of geometric contours [12]. Hereunder these equations are listed. Note that $Q$ is -1 for the area minimizer $\int d A$ and $-\kappa$ for the arclength minimizer $\int d s$. The data term $\mathcal{D}$ has the constituent

$$
Q=\mathbf{t} \cdot\left(\Phi_{\mathrm{nr}}-\kappa \Phi_{\mathbf{n n}}\right) \cdot \mathbf{t}+\kappa\left(\Phi_{\mathbf{n}} \cdot \mathbf{n}-\Phi\right)+\Phi_{\mathbf{r}} \cdot \mathbf{n},
$$

where $\mathbf{t}, \mathbf{n}$ are the local basis. Eq. (4.13) can be specialized for unique problems represented by the function $\Phi$. For image segmentation, any regional image statistics, like intensity, mean difference or Mahalanobis distance between the regions on the two sides of the contour, can be used. The first order quantities $\Phi_{\mathbf{r}} \cdot \mathbf{n}, \Phi_{\mathbf{n}} \cdot \mathbf{n}$ are the differences of the corresponding expressions of the local integrals $\phi^{+}, \phi^{-}$. In the equations $\phi^{ \pm}$represents either $\phi^{+}$or $\phi^{-}$:

$$
\begin{aligned}
& \phi_{\mathbf{r}}^{ \pm} \cdot \mathbf{n}=\iint \nabla I \cdot \mathbf{n} d A \\
&=\iint I_{\eta} d A, \\
& \phi_{\mathbf{n}}^{ \pm} \cdot \mathbf{n}=0,
\end{aligned}
$$

and the second order quantities are $\mathbf{t} \cdot \Phi_{\mathrm{nr}} \cdot \mathbf{t}, \mathbf{t} \cdot \Phi_{\mathbf{n n}} \cdot \mathbf{t}$ are specified as the differences of:

$$
\begin{aligned}
\mathbf{t} \cdot \phi_{\mathbf{n r}}^{ \pm} \cdot \mathbf{t} & =\iint(-\xi \mathbf{n} \cdot \nabla \nabla I \cdot \mathbf{t}+\eta \mathbf{t} \cdot \nabla \nabla I \cdot \mathbf{t}) d A \\
& =\iint\left(-\xi I_{\eta \xi}+\eta I_{\xi \xi}\right) d A,
\end{aligned}
$$




$$
\begin{aligned}
\mathbf{t} \cdot \phi_{\mathbf{n n}}^{ \pm} \cdot \mathbf{t} & =\iint(-\xi \mathbf{n}+\eta \mathbf{t}) \cdot \nabla \nabla I \cdot(-\xi \mathbf{n}+\eta \mathbf{t}) d A \\
& +\iint(-\xi \nabla I \cdot \mathbf{t}-\eta \nabla I \cdot \mathbf{n}) d A \\
& =\iint \xi^{2} I_{\eta \eta}-2 \xi \eta I_{\xi \eta}+\eta^{2} I_{\xi \xi}-\left(\xi I_{\xi}+\eta I_{\eta}\right) d A
\end{aligned}
$$

If the image is not plagued with a significant amount of noise, the simpler 'pointwise version' of the local region equation can be used with the corresponding functional $\oint \mathbf{n} \cdot \nabla I d s$ and the Euler-Lagrange equation:

$$
|\dot{\mathbf{r}}| \triangle I \mathbf{n}=0
$$

where $\triangle I$ is the Laplacian of $I$ and can be calculated either in the standard basis $\mathbf{i}, \mathbf{j}$ as $\triangle I=I_{x x}+I_{y y}$ or in the local basis $\mathbf{t}, \mathbf{n}$ as $\triangle I=I_{\xi \xi}+I_{\eta \eta}$. This problem is discussed in [86]. Derivations can be found in Appendix B. Note that the proposed data term was constructed to behave as a scale invariant term of the overall energy in the model.

In the equation for the plasma size and shape prior $\mathcal{E}_{\mathcal{S H}-\mathcal{P}}$, the constituent $Q$ has the form:

$$
\begin{aligned}
& -\frac{1}{A_{0}^{2}}\left|\oint d A-A_{0}\right| \\
& -\frac{\lambda}{A_{0}^{2}}\left(\oint d A-\frac{1}{q}(\oint d s)^{2}\right)\left(1-\kappa \frac{2}{q} \oint d s\right) \\
& +\mu\left[\left(\frac{d^{2} \kappa}{d s^{2}}+\frac{1}{2} \kappa^{3}\right) \oint d s-\frac{\kappa}{2} \oint \kappa^{2} d s\right],
\end{aligned}
$$

where $\left|\oint d A-A_{0}\right|$ is the absolute value of $\oint d A-A_{0}$. In the equation for the ellipse shape prior $\mathcal{E}_{\mathcal{S H}-\mathcal{E}}$ (derivation can be seen in Appendix B) $Q$ is given by:

$$
\begin{aligned}
& -\frac{1}{A_{0}^{3}}\left(\oint d A-A_{0}\right)^{2} \\
- & \frac{\lambda}{\left(A_{0} L_{0}\right)^{2}}\left(\oint d A \oint d s-q \oint\left|\mathbf{r}_{0 t}\right|^{2} d s\right) \\
& {\left[\oint d s+\kappa \oint d A+q\left(2 \mathbf{r}_{0 t} \cdot \mathbf{n}-\left|\mathbf{r}_{0 t}\right|^{2} \kappa\right)\right] } \\
& -\frac{\mu}{L_{0}} \kappa .
\end{aligned}
$$

From a theoretical point of view, the products of integrals in the shape and size functions constitute higher-order active contours, but their Lagrangians defined as a 
constant kernel integral transform. The functional derivative of such higher-order integrals can formally be derived as if they were simply the composite functions of the constituent (first order contour) integrals.

The derivation of the Euler-Lagrange equation for an arbitrary function of the signed curvature $\kappa$ can be found in Appendix B.

\subsubsection{Solving the Euler-Lagrange equation}

We solve the Euler-Lagrange equation with gradient-descent iteratively. Two of the frequently used usual curve representations are:

- using Lagrangian coordinates the curve is defined by its points or

- using Euler coordinates the curve is defined indirectly as the interface of a level set surface.

With the Lagrangian description, tracking the topology changes of the curve is difficult. This description is preferable when there are no potential topology changes, or when the initial topology is intentionally enforced. The level set method [33] uses the latter representation. In this case, the internal and the external parts of a closed curve are naturally represented by positive and negative level set function values, thus the topology changes are easy to track which is essential in our case.

\section{Calculating quantities on grid}

Level set methods used as numeric solvers require the quantities to be calculated on a fixed grid. Most constituents are formally given by the formulae:

$$
\begin{aligned}
\mathbf{n} & \rightarrow \frac{\nabla U}{|\nabla U|} \\
\kappa & \rightarrow-\nabla \cdot \frac{\nabla U}{|\nabla U|} \\
|\dot{\mathbf{r}}| & \rightarrow|\nabla U|,
\end{aligned}
$$

where $U(\mathbf{r})$ is the level set function having a constant value at the contour's points $U(\mathbf{r}(t))=z$ (the constant $z$ is often chosen to be zero), and the curvature $\kappa$ is the negative divergence of the gradient of the normalized level set function. All these quantities are given at each point of the image domain. The directional derivative along the contour of any function $f(\mathbf{r}(t))$ can be calculated as $\frac{d f}{d t}=\frac{\partial f}{\partial x} \frac{d x}{d t}+\frac{\partial f}{\partial y} \frac{d y}{d t}$, i.e. $\frac{d f}{d t}=\nabla f \cdot \dot{\mathbf{r}}$. The derivative w.r.t. the arclength is related to the derivative w.r.t. arbitrary curve parameter $t$ as $\frac{d}{d s}=\frac{1}{|\dot{\mathbf{r}}|} \frac{d}{d t}$, hence: 


$$
\begin{aligned}
\frac{d^{2} \kappa}{d s^{2}} & =\frac{1}{|\dot{\mathbf{r}}|} \frac{d}{d t}\left(\frac{1}{|\dot{\mathbf{r}}|} \frac{d \kappa}{d t}\right) \\
& =\frac{\dot{\mathbf{r}}}{|\dot{\mathbf{r}}|} \cdot\left[\nabla\left(\frac{\nabla \kappa \cdot \dot{\mathbf{r}}}{|\dot{\mathbf{r}}|}\right)\right] \\
& =[\nabla(\nabla \kappa \cdot \mathbf{t})] \cdot \mathbf{t},
\end{aligned}
$$

where $\mathbf{t}=\mathbf{n} \times \mathbf{k} ; \mathbf{n}, \kappa$ are defined by the level set expressions (4.21).

\subsubsection{Verification}

In this section we demonstrate the results on various synthetic tests. We present the shape and size selection capabilities of the mixed functional. Then we demonstrate the stability of the model under noisy imaging conditions.

We used the level set implementation of the model [33]. For every test case, we used rectangular initialization of the level set slightly smaller than the image size.

Fig. 4.5 shows the results obtained on synthetic images where we demonstrate the size and shape separation efficiency of the proposed model. In the first three images we tested the mixed model on objects of various sizes. In the fourth image we present the selectiveness on a mixture of object of different sizes and shapes. $H W S_{l o c}=4(=p=q)$ was used as the local window half size (Fig. 4.3). The presented active contour model was able to successfully select shapes of different size and select the desired objects from largely mixed object populations.

We compared the proposed method to the higher-order active contours 'gas of circles' model (HOAC GOC) [39]. Both models were executed on 20 images containing three shapes in two sizes. An example image of this set is shown in the bottom right image of Fig. 4.5. We measured recognition accuracy by comparing the pixel level Jaccard index (JI) values. Results are summarized in Fig. 4.6.

The proposed method slightly outperformed the HOAC GOC model on selectively segmenting circles, while it was remarkably better for elliptical and plasma-like object detection.

The robustness of the model to noise was tested with different levels of Gaussian white noise. 200 images were generated containing circular and elliptical objects and different levels of Gaussian noise were added [signal-to-noise ratio SNR $=5,0,-5,-6.6$, -8.2 and $-10 \mathrm{~dB}]^{7}$. First minor segmentation errors were observed at $-6.6 \mathrm{~dB}$, showing that the proposed model is very stable against extreme noise levels. The results are shown in Fig. 4.7 at various noise levels. To obtain the results we used the local region based data term with the same weights discussed in Section 4.1.6.

\footnotetext{
${ }^{7}$ We remark that $\mathrm{SNR}=0 \mathrm{~dB}$ means that the noise variance is equal to the signal variance.
} 


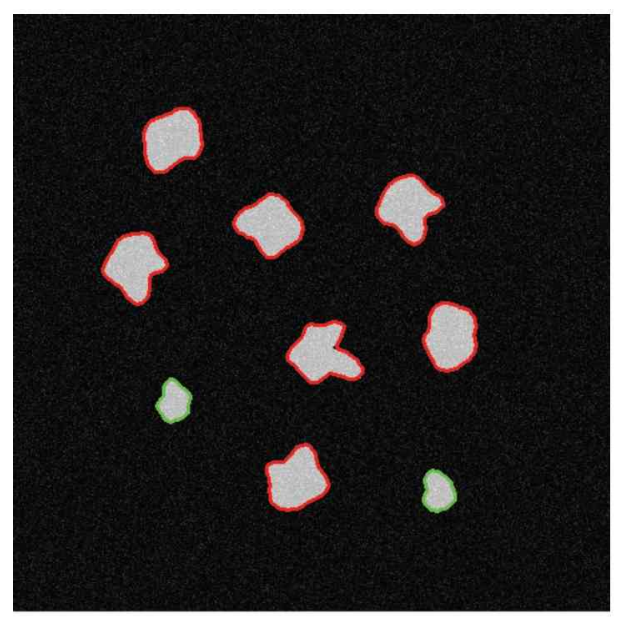

Plasma shape

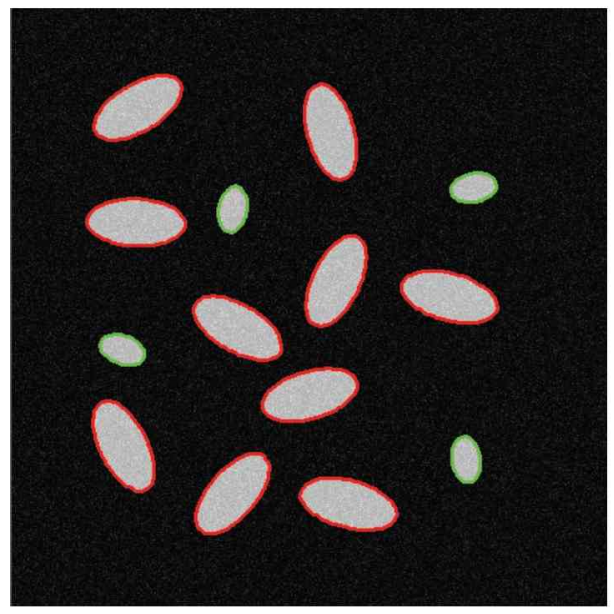

Ellipse shape

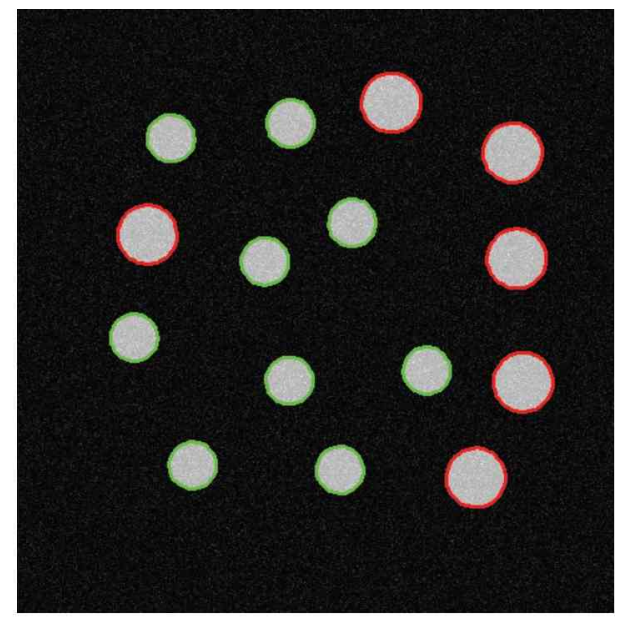

Circle shape

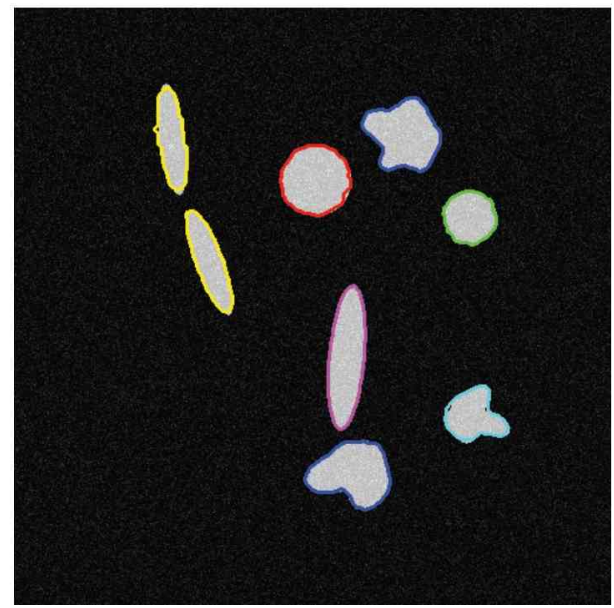

Mixed shape

Figure 4.5: Results of the selective segmentation framework. The upper left image contains two plasma shapes of different sizes with the same perimeter ${ }^{2} /$ area ratio. The upper right image has two type of circles of different sizes. The lower left one has two ellipses of different sizes with the same ratio between the minor and major axes. The lower right image contains objects of different shapes and sizes. Segmentation results of various settings are represented by unique contour colours.

\subsection{Multi-layered selective active contours}

Similarly to the GOC phase field model, we can extend the selective active contour model to a multi-layered model to represent overlapping objects. Multiple instances of the basic geometric model being used as layers over each other can deal with the problem of the shared image subdomain between overlapping objects. In this case overlapping objects can be placed on different layers of the model.

We combined the image model developed for fluorescent imaging modality with the multi-layered selective active contour model. The additive data model is designed 


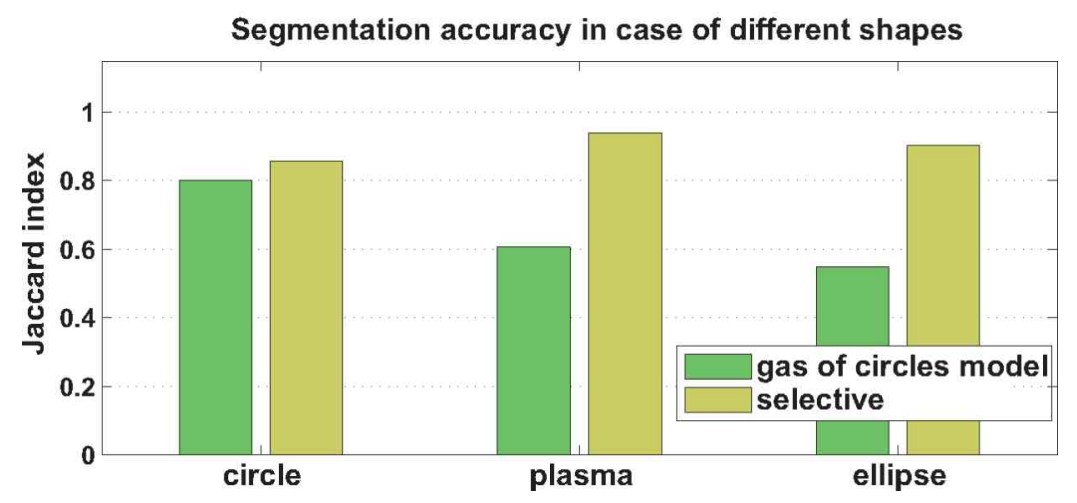

Figure 4.6: Comparison results between the higher-order active contours 'gas of circles' model with the proposed selective segmentation framework. The proposed model recognized circles with higher accuracy and largely outperformed the other model on selectively segmenting elliptical and plasma-like objects.

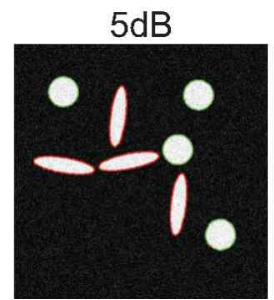

$-6.6 \mathrm{~dB}$

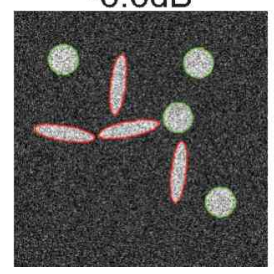

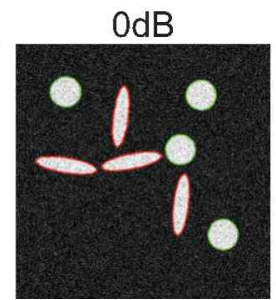

$-8.2 \mathrm{~dB}$

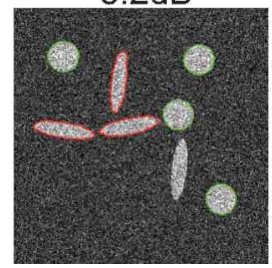

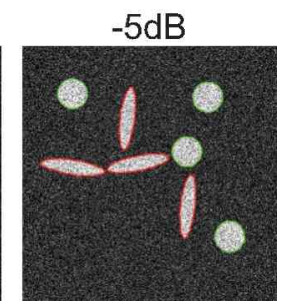

$-10 d B$

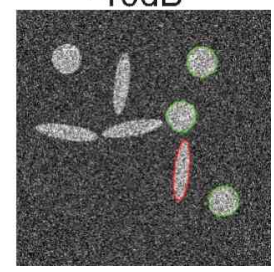

Segmentation results on noisy images

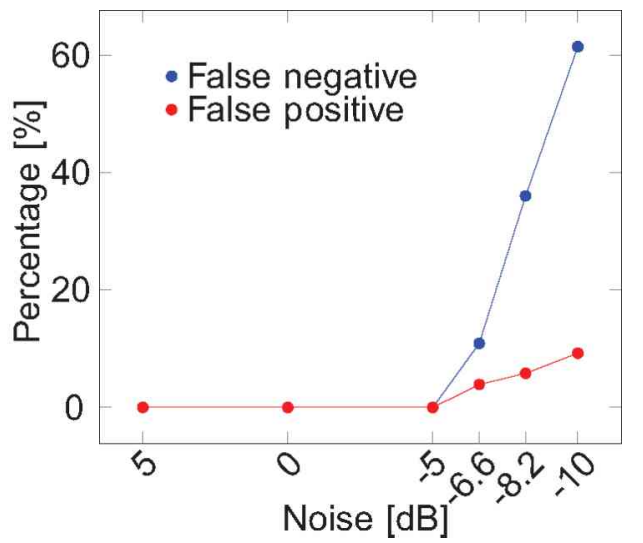

Figure 4.7: Noise test results, where $\mathrm{SNR}=5,0,-5,-6.6,-8.2$ and $-10 \mathrm{~dB}$ was added to the image. We used Gaussian white noise and two different shapes to test the selective segmentation framework in the presence of noise.

intuitively on the assumption that multiple cells overpositioned on each other contribute to the measured pixel intensity, and this intensity can be written as an additive function of the intensity of a single cell.

Since the optimization uses the level set implementation of the selective active contour model, we can give the data model with compatible formulation.

Let $U_{+}=\sum_{i=1}^{\ell} \frac{\left(\tanh \left(U^{(i)}\right)+1\right)}{2}$ (Fig. 4.8), where $U^{(i)}$ is the level set function in the $i^{\text {th }}$ layer. The individual level set layers are restricted between -1 and 1 by applying tanh on them, therefore $U_{+}$'counts' the number of cells at each point.

The gradient descent optimization method is used to minimize the overall energy of the selective active contour. Evolution of the contours are driven by the Euler-Lagrange 


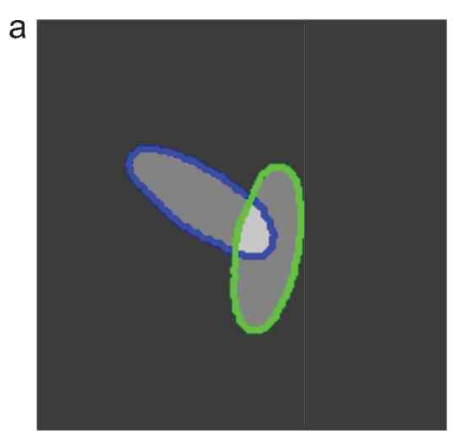

b

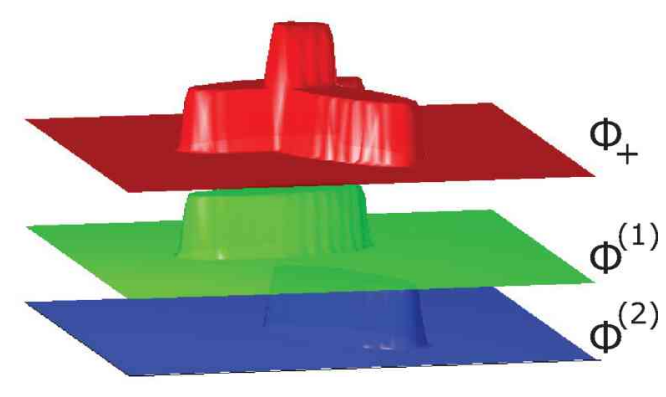

Figure 4.8: Illustration of the proposed data model. (a) Synthetic image of two overlapping ellipses. (b) Final stable level set function on the image (a), showing the two layers, and the combined $\phi_{+}$function that 'counts' cells.

equations of the individual layers and the functional derivatives of the additive data model. The corresponding equations are given in Chapter 2, Chapter 3 and in Appendix A.

\subsubsection{Experiments}

We tested how the selective active contour framework and the level set based data model can co-operate with each other. For this test we created synthetic images of overlapping objects with different shapes. To test the multi-layered selective model on real data we used microscopic images of prostate cancer cells and bacteria. For shape prior $q_{C}=\frac{(\oint d s)^{2}}{\oint d A}$ was used.

In our synthetic tests we investigated the separation ability of the proposed model. We have shown that the used additive data model is robust against noise [75]. The test images have $0 d B$ signal-to-noise ratio.

As seen in Fig. 4.9, with a proper ratio of the geometric and data terms the combined model works as it is expected: both requirements of shape and size are satisfied, and the contours fit to image data.

We tested the multi-layered model using 2 layers on overlapping ellipsoids. Fig. 4.10 demonstrates that we may obtain almost perfect contours of the original objects. Different levels of overlapping and different orientations or positions of the ellipses were also tested. 
Circle shape parameters
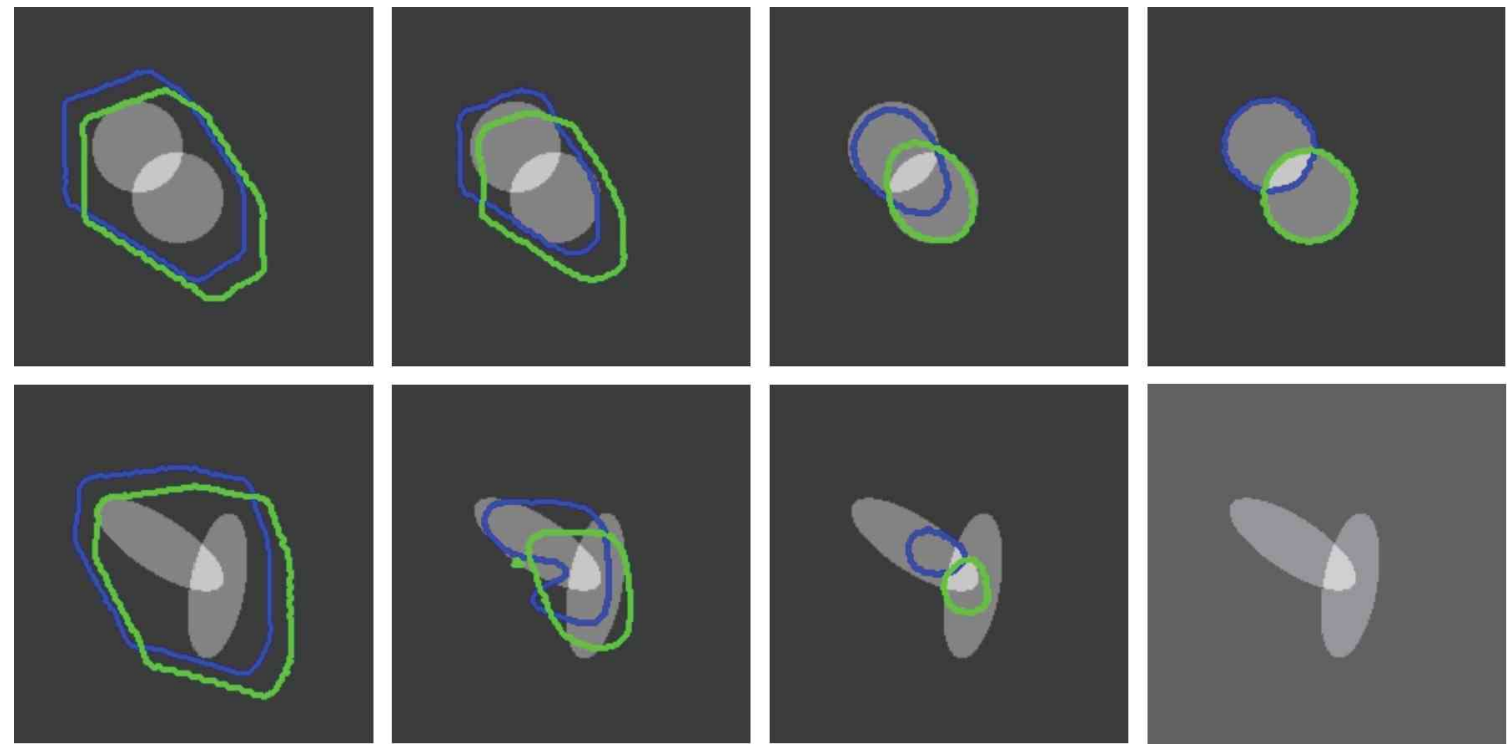

Ellipse shape parameters
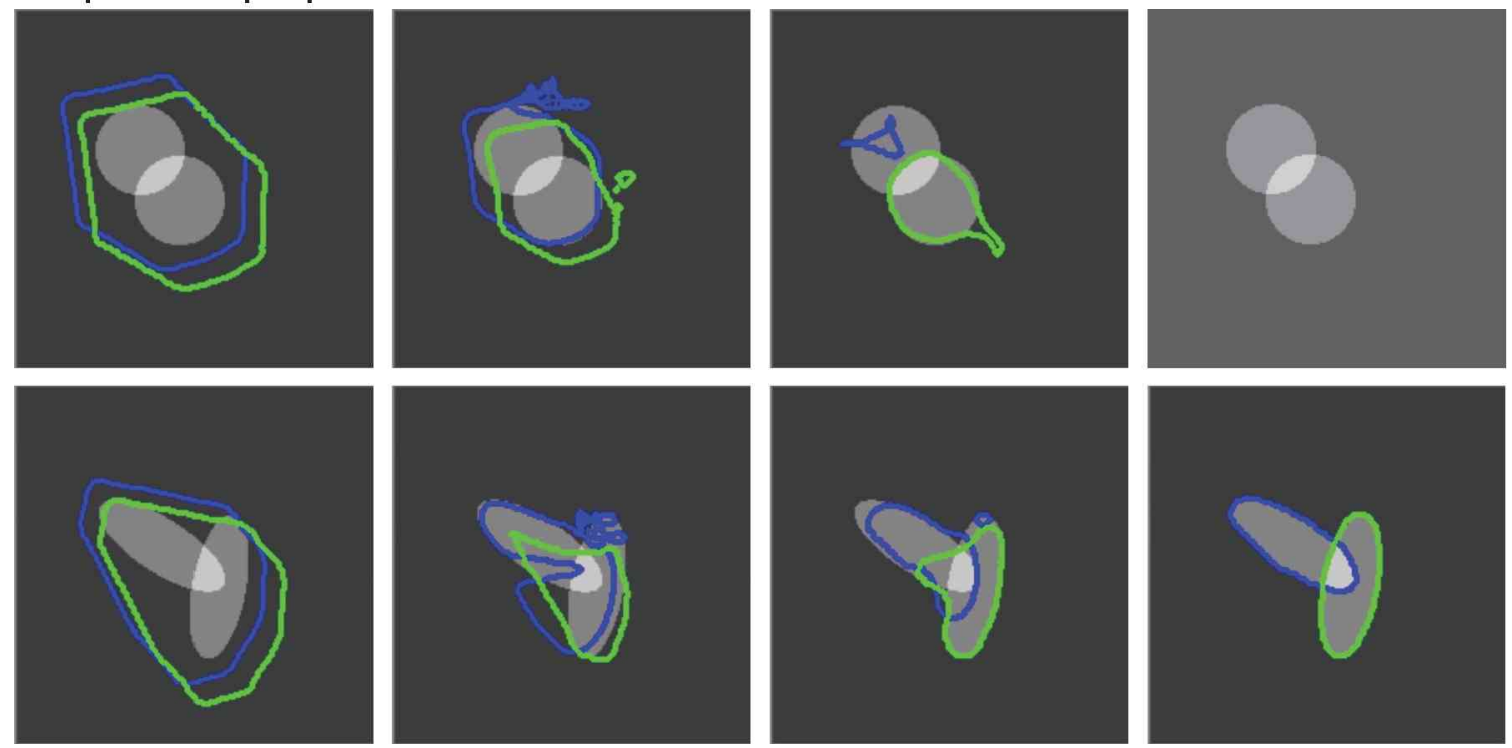

Figure 4.9: Evolution of contours preferring different shapes. To favour circles and ellipses we used $q_{C}=12.56$ and $q_{C}=17.8$, respectively. 

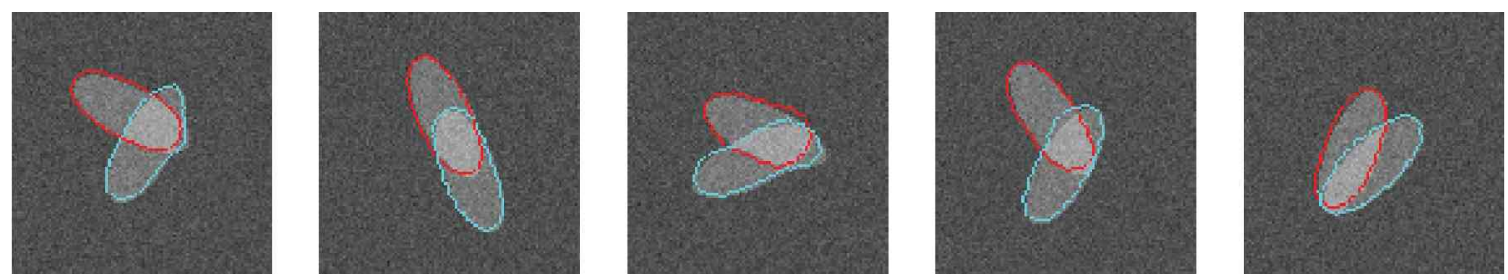

Figure 4.10: Segmentation results on synthetic noisy images containing overlapping ellipses of area 750 (pixels) and $q_{C}=16.5$ (see Eq. (4.3)).

In respect of square perimeter to area ratio, ellipsoids are equal to 'plasma' shapes. We generated configurations of overlapping shapes of a fixed preferred area and $q_{C}$ by generating a single object and moved a transformed copy (e.g. rotation, reflection) of this individual template over it. Separation of such shapes is also hard for the human eye and more than one proper solutions are possible. Fig. 4.11 shows the results on noisy images of these 'plasma' shapes. Note that the gradient descent method was used for optimization, and thus it is very sensitive to the initialization (see Fig. 4.11 center images).
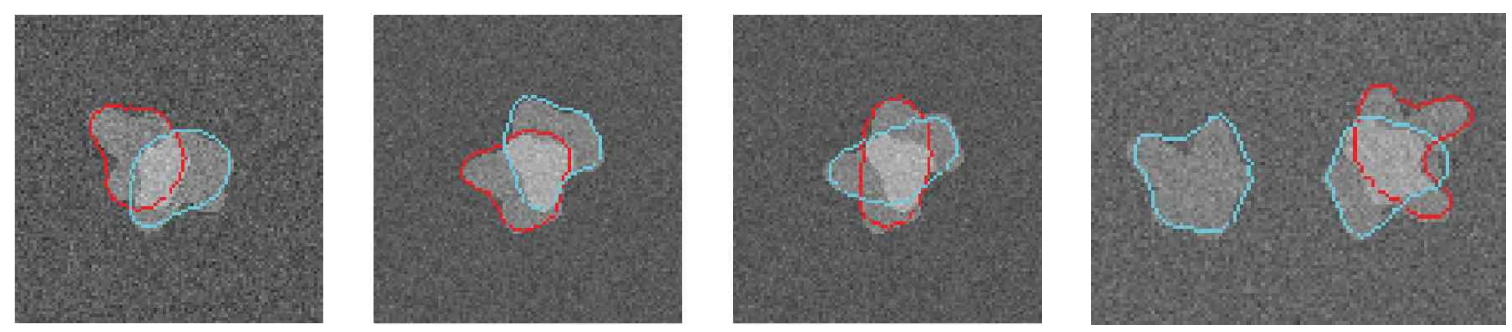

Figure 4.11: Segmentation results on synthetic noisy images of overlapping 'amoeba' (or 'plasma') shapes. Note that in the third image the ellipse-like segmentation does not track the contours of the original (ground truth) objects.

We also tested the new model on microscopic images of prostate cancer cells (see Fig. 4.12). With proper size and shape parameters we can achieve fast and accurate extraction of object contours.
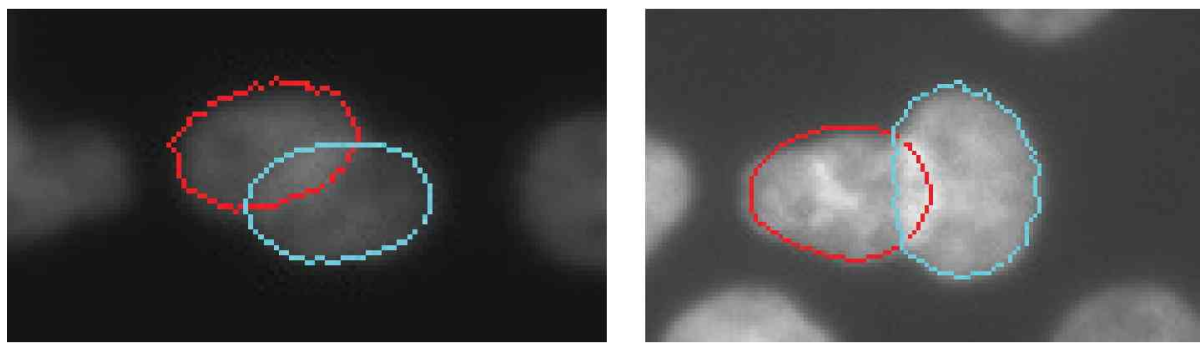

Figure 4.12: Segmentation of overlapping prostate cancer cell nuclei with the multilayered selective active contour model. 


\subsubsection{Computational complexity}

The method uses single line integrals over boundary contour to compute the geometric part. It gives that the order of the number of local calculations is $\mathcal{O}(N)$, where $N$ is the number of the pixels of the image. Note that a narrow band algorithm was used on level sets that represent the contours. The computation of data part in a single iteration is proportional to the pixel number and the number of used layers of the level set functions: $N / h^{2} * L$ where $\mathrm{h}$ is the level set spacing or grid size, $\mathrm{L}$ is the number of layers of level set functions; therefore the data term needs also $\mathcal{O}(N)$ calculations. This means that the running time is under 1 minute on $100 \times 100$ images, using 2 layers and $2 \times 2$ grid size of level sets. The exact running time, i.e. to get a stable final contour or level set, highly depends on the complexity of the image. 



\section{Chapter 5}

\section{Object splitting with active contours}

This chapter introduces the 'cutting arms' active contour model for splitting of aggregated objects which are not distinguishable based on image information only. The assumption behind the idea is that it is possible to identify dents on the object groups' boundary when two adjacent cells are touching. Thus, by connecting opposite dents, i.e. the concave points of the boundary of object groups, one can have the border line between two adjacent cells. To 'connect' the elements of these opposite point pairs we developed a higher-order active contour model (HOAC).

In many biological applications cells have a non-uniform spacial distribution. From the practical (image processing) point of view, it means that upon exceeding a certain density of cells, the classical segmentation methods do not give single, separated cells, but groups of touching objects/cells. To analyze individual objects, further processing is needed, which can separate the clumped objects.

As it was presented in previous chapters, HOAC models are able to describe nonlocal interactions between distant points of the object boundary. This ability makes it possible to add shape information to the classical energy of the active contour models without using any template shapes of the target objects. It can also provide a tool for object splitting in the form of an attractive force between the contour points which satisfy certain properties, namely (1) they are not too far from each other, (2) they are aligned, and (3) they are concave points of the contour.

To design the functional for splitting we used an analogy from electrostatics. The idea comes from the variational formulation of charge density distribution on a conductor surface. In our case the surface is a planar curve, the attractive force is defined by the normal of the curve at a given contour point instead of the charge density, and the 'attractive charges' are fixed to the contour points. Hence the mentioned changes force the contour's evolution to split the aggregated objects if the object group satisfies the assumptions for the shape of aggregation. Details of the splitting functional are shown in Section 5.1. 


\section{1 'Cutting arms' splitting model}

In this section we introduce the HOAC model designed to efficiently split cell clumps into simple, non-further-splittable parts [87]. In our tests presegmentation was performed by a local-region based active contour which effectively tracks object boundaries even if they are slightly overlap or touch each other [85, 88]. It should be noted, however, that the presegmentation step can be done by any segmentation methods which provides the assumed concave 'dents' between two adjacent objects.

After the presegmentation step, remaining objects no longer have edges to be tracked. A purely geometric splitting functional (see section Eq. (5.1.1)) is designed as a second step that splits these objects further by penalizing high curvature contour regions (see Fig. 5.1) and moving them towards each other until they cut the original object into two.

We use the notations of Chapter 4 to formulate the 'cutting arms' HOAC model for object splitting.

\subsubsection{The splitting functional}

The higher-order splitting functional was designed by using an analogy from electrostatics, as we have mentioned before. The variational formulation of the charge density distribution $\varrho(\mathbf{r})$ on a conductor can be characterized with the total potential energy of the system as: $\oint \oint \varrho(\mathbf{r}) \varrho\left(\mathbf{r}^{\prime}\right) l\left(d\left(\mathbf{r}, \mathbf{r}^{\prime}\right)\right) d \Omega d \Omega^{\prime}$, where $d\left(\mathbf{r}, \mathbf{r}^{\prime}\right)$ is the Euclidean length between two points of the conductor, $l(d)=\frac{1}{\left|\mathbf{r}-\mathbf{r}^{\prime}\right|}$. The minimizer of this system ${ }^{1}$ is the equipotential distribution of the charge on the conductor surface. We will use this analogy with the following differences: a) the problem is applied to planar curves; b) the force acting between the contour points is attractive and anisotropic (explained later); c) the 'attractive charges' are fixed to the contour points, and hence the contour evolves to reach the minimal energy.

First, we assume that the set of objects that compose the clump of nuclei cannot be further segmented using the method of presegmentation (Eq. (4.11)) due to missing edge information between the parts. The splitting functional should therefore be based on purely geometric information. Second, we reduce the set of contour points to a subset satisfying certain concavity and alignment criteria. We call it 'feasible subset'. The complement set of the 'feasible subset' remains intact during the process. The feasible contour points are handled as a weighted, oriented particle set. The associated orientation is defined by their normal vector $\mathbf{n}$, and the weights are defined by their concavity as shown in Fig. 5.1. Within an energy minimization framework for curve evolution, concavity is indicated by the negative curvature of the curve $(\kappa<0)$. The alignment of two oriented points (indexed by 1,2$)$ is defined by the relation of their orientations and relative position such that $a_{12} \doteq \mathbf{n}_{1} \cdot \mathbf{e}_{12}+\mathbf{n}_{2} \cdot \mathbf{e}_{21}$, where $\mathbf{e}_{12}$ is the unit normal vector pointing from point 1 to 2 , and $\mathrm{e}_{21}=-\mathrm{e}_{12}$. Note that this definition of the alignment is symmetric, i.e. $a_{12}=a_{21}$. Now one can define the 'anisotropic energy' for a pair of points as $U_{12} \doteq f_{c}\left(\kappa_{1}\right) f_{c}\left(\kappa_{2}\right) g_{a}\left(a_{12}\right) l\left(d_{12}\right)$ with $d_{12}$ being the Euclidean

\footnotetext{
${ }^{1}$ Extended by the charge conservation principle.
} 
distance between the points and $f_{c}, g_{a}, l$, are appropriately chosen functions discussed in the next subsection. Taking $f_{c}(\kappa(s))$ as the density of the potential source (the 'attractive charge' ${ }^{\prime}$ ) along the contour, the second-order functional

$$
E_{C A}=-\iint_{\mathbf{r}_{F S} \times \mathbf{r}_{F S}^{\prime}} f_{c}(\kappa(s)) f_{c}\left(\kappa\left(s^{\prime}\right)\right) g_{a}\left(a\left(s, s^{\prime}\right)\right) l\left(d\left(s, s^{\prime}\right)\right) d s d s^{\prime}
$$

represents the total energy of the contour. The integral is evaluated only on the feasible subset, defined as:

$$
\mathbf{r}_{F S}=\left\{\mathbf{r}(s) \mid \kappa(s)<-\varepsilon \wedge a\left(s, s^{\prime}\right)>\delta\right\}
$$

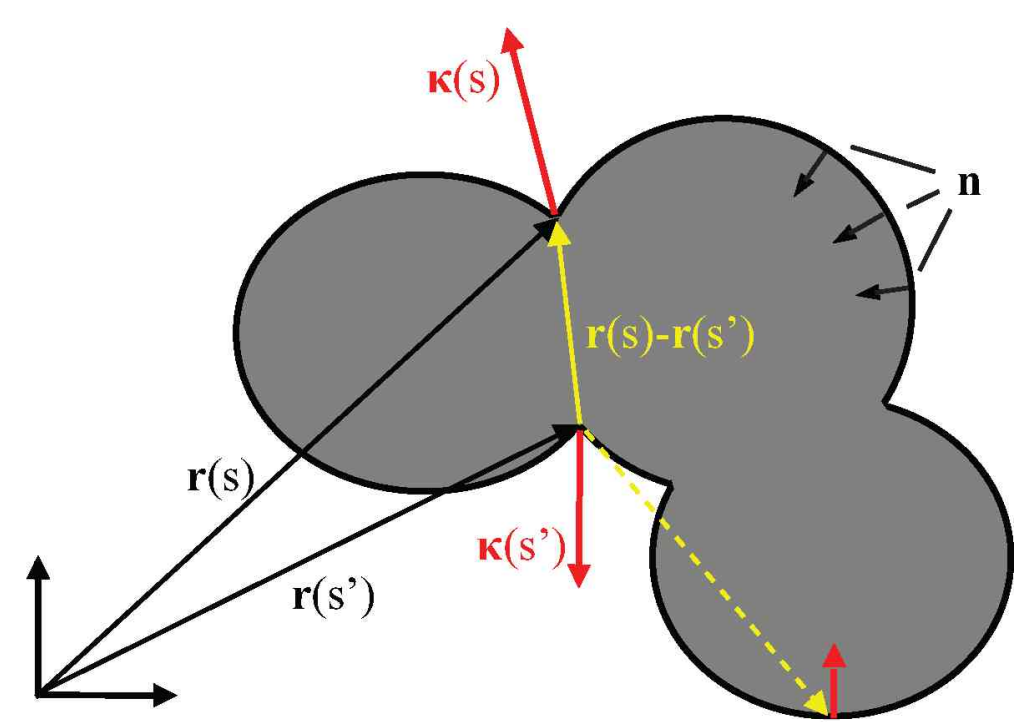

Figure 5.1: Illustration of the object cutting method. Contour points connected by the continuous line are well aligned, whilst points connected by the dashed line are not.

Contour points out of the 'feasible subset' do not contribute to total energy. Note that the minimization of the negative of the simplified functional with $g \equiv 1, l \equiv 1$ would result in the convex hull of the initial contour. Functional given in Eq. (5.1) represents a geometric contour since the associated Euler-Lagrange equation has a component only in the normal direction (see Appendix C). We solve it iteratively via gradient descent, using the level set method.

\subsubsection{Roles of the functions in splitting functional}

The most important part of the Lagrangian Eq. (5.1) is the alignment function $g_{a}\left(a\left(s, s^{\prime}\right)\right)$. The appropriately designed function keeps the correct orientation (prevents biasing from the aligned direction) between the approaching tips of the 'cutting arms' during the

\footnotetext{
${ }^{2}$ hence the negative sign
} 

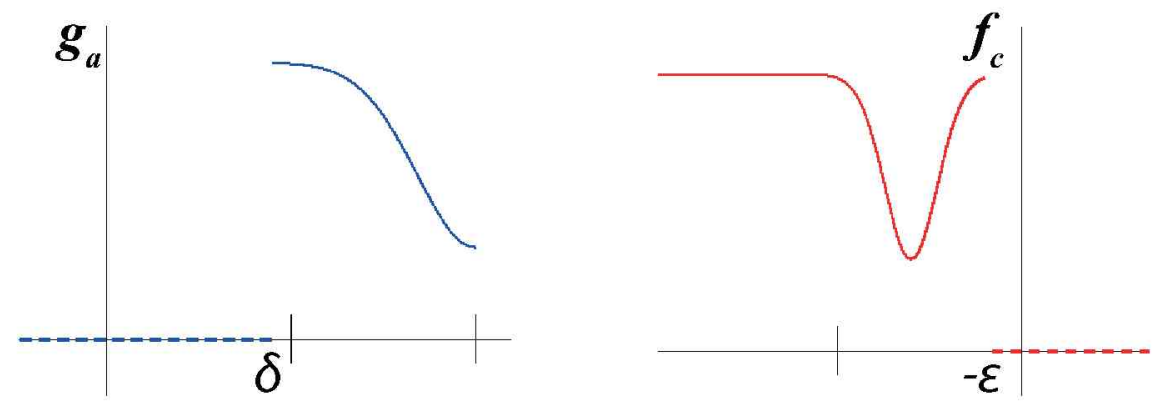

Figure 5.2: Functions of the alignment (left) and the curvature (right) functions. Both can be considered as potential barriers. Points outside the feasible subset are marked with a dashed line.

evolution process. It also guarantees the stability of the cutting arm preventing it from unexpected bifurcation. Note that we use the smooth version of the curvature for the same reasons (smoothing is done by simple averaging of the curvatures of a small neighbourhood). The function in Fig. 5.2 left acts as a potential barrier with minimum at the maximal alignment. The simplest splitting functional contains only the alignment function (this special form can be derived from the general functional setting the other constituent functions $f_{c}, l$ identically constant one). However, this would represent a system with energy indiscriminate w.r.t the distance between the points of the feasible subset.

To favour point pairs otherwise appropriate, the distance function $l\left(d\left(s, s^{\prime}\right)\right)$ is introduced in the functional Eq. (5.1) such that closer points exhibit a larger attractive force than further ones. The distance function may have limited scope as well.

The suitable function of the curvature can provide further stability for the 'cutting arms' enforcing their tips to favour a certain curvature value, thus make further bifurcations unlikely. This function can be chosen to be a potential barrier. Its minimum value determines the curvature of the cutting tip, and hence the width of the cutting arms as well (Fig. 5.2).

\subsubsection{Optimizing by gradient descent}

Optimization was performed by the gradient descent method. For this purpose, the following Euler-Lagrange equation was derived.

The formula: $A=\mathbf{e}_{t \tau} \cdot(\mathbf{e}(t)-\mathbf{e}(\tau)), B=\mathbf{e}_{t \tau} \cdot(\mathbf{n}(t)-\mathbf{n}(\tau))$, $C=\left[\frac{l\left(d_{t \tau}\right)}{d_{t \tau}}-l^{\prime}\left(d_{t \tau}\right)\right], D=\mathbf{e}_{t \tau} \cdot \mathbf{n}(t), E=\mathbf{e}_{t \tau} \cdot \mathbf{e}(t), F=\mathbf{n}(\tau) \cdot \mathbf{e}(t)$ are introduced to simplify the equation. The Euler-Lagrange equation associated with the half of Eq. (5.1) at point $t$ has the form $|\mathbf{r}(t)| Q \mathbf{n}(t)=0$, where $Q$ is given by the following sum: 


$$
\begin{aligned}
& Q=-\left[f_{c}^{\prime \prime \prime}\left(\frac{d \kappa}{d s}\right)^{2}+f_{c}^{\prime \prime} \frac{d^{2} \kappa}{d s^{2}}\right] \oint g_{a}\left(a_{t \tau}\right) l\left(d_{t \tau}\right) f_{c}(\kappa(\tau)) d s \\
& -2 f_{c}^{\prime \prime} \frac{d \kappa}{d s} \oint g_{a}^{\prime}\left(a_{t \tau}\right) l\left(d_{t \tau}\right) \frac{A D}{d_{t \tau}} f_{c}(\kappa(\tau)) d s \\
& +2 f_{c}^{\prime \prime} \frac{d \kappa}{d s} \kappa \oint g_{a}^{\prime}\left(a_{t \tau}\right) l\left(d_{t \tau}\right) E f_{c}(\kappa(\tau)) d s \\
& +2 f_{c}^{\prime \prime} \frac{d \kappa}{d s} \oint g_{a}\left(a_{t \tau}\right) l^{\prime}\left(d_{t \tau}\right) E f_{c}(\kappa(\tau)) d s \\
& -f_{c}^{\prime} \oint g_{a}^{\prime \prime}\left(a_{t \tau}\right) l\left(d_{t \tau}\right)\left[\frac{\left(B-\kappa(t) d_{t \tau}\right) E+F}{d_{t \tau}}\right]^{2} f_{c}(\kappa(\tau)) d s \\
& +f_{c}^{\prime} \kappa \oint g_{a}^{\prime}\left(a_{t \tau}\right) l\left(d_{t \tau}\right) \frac{A E-2}{d_{t \tau}} f_{c}(\kappa(\tau)) d s \\
& +f_{c}^{\prime} \kappa^{2} \oint g_{a}^{\prime}\left(a_{t \tau}\right) l\left(d_{t \tau}\right) D f_{c}(\kappa(\tau)) d s \\
& +f_{c}^{\prime} \oint g_{a}^{\prime}\left(a_{t \tau}\right) l\left(d_{t \tau}\right) \frac{B D^{2}}{d_{t \tau}^{2}} f_{c}(\kappa(\tau)) d s \\
& -2 f_{c}^{\prime} \oint g_{a}^{\prime}\left(a_{t \tau}\right) \frac{A C D E}{d_{t \tau}} f_{c}(\kappa(\tau)) d s \\
& +2 f_{c}^{\prime} \kappa \oint g_{a}^{\prime}\left(a_{t \tau}\right) C E^{2} f_{c}(\kappa(\tau)) d s \\
& -f_{c}^{\prime} \kappa^{2} \oint g_{a}\left(a_{t \tau}\right) l\left(d_{t \tau}\right) f_{c}(\kappa(\tau)) d s \\
& +\int_{c}^{t} \kappa \oint g_{a}\left(a_{t \tau}\right) l^{\prime}\left(d_{t \tau}\right) D f_{c}(\kappa(\tau)) d s \\
& -f_{c}^{\prime} \oint g_{a}\left(a_{t \tau}\right) l^{\prime}\left(d_{t \tau}\right) \frac{D^{2}}{d_{t \tau}} f_{c}(\kappa(\tau)) d s \\
& -f_{c}^{\prime} \oint g_{a}\left(a_{t \tau}\right) l^{\prime \prime}\left(d_{t \tau}\right) E^{2} f_{c}(\kappa(\tau)) d s \\
& +f_{c} \kappa \oint g_{a}^{\prime \prime}\left(a_{t \tau}\right) l\left(d_{t \tau}\right) E^{2} f_{c}(\kappa(\tau)) d s \\
& -f_{c} \oint g_{a}^{\prime \prime}\left(a_{t \tau}\right) l\left(d_{t \tau}\right) \frac{A D E}{d_{t \tau}} f_{c}(\kappa(\tau)) d s \\
& -f_{c} \kappa \oint g_{a}^{\prime}\left(a_{t \tau}\right) l\left(d_{t \tau}\right) D f_{c}(\kappa(\tau)) d s \\
& -f_{c} \oint g_{a}^{\prime}\left(a_{t \tau}\right) l\left(d_{t \tau}\right) \frac{D^{2}-A E}{d_{t \tau}} f_{c}(\kappa(\tau)) d s \\
& +f_{c} \oint g_{a}^{\prime}\left(a_{t \tau}\right) l^{\prime}\left(d_{t \tau}\right) E^{2} f_{c}(\kappa(\tau)) d s \\
& +f_{c} \oint g_{a}\left(a_{t \tau}\right)\left[\kappa(t) l\left(d_{t \tau}\right)+l^{\prime}\left(d_{t \tau}\right) D\right] f_{c}(\kappa(\tau)) d s .
\end{aligned}
$$


The factors outside the integrals are calculated at parameter $t$ (i.e. independent of the bound variable). Note that any factor depending only on parameter $t$, could be brought before the integrals, but would lead to a more complicated expression. More details can be found in Appendix C.

\subsubsection{Verification}

We demonstrate the behaviour of the geometric model on different initial group of shapes (Fig. 5.3). To demonstrate the segmentation ability of the proposed method we present quantitative results on synthetic images and qualitative results on real images of cancer cells.

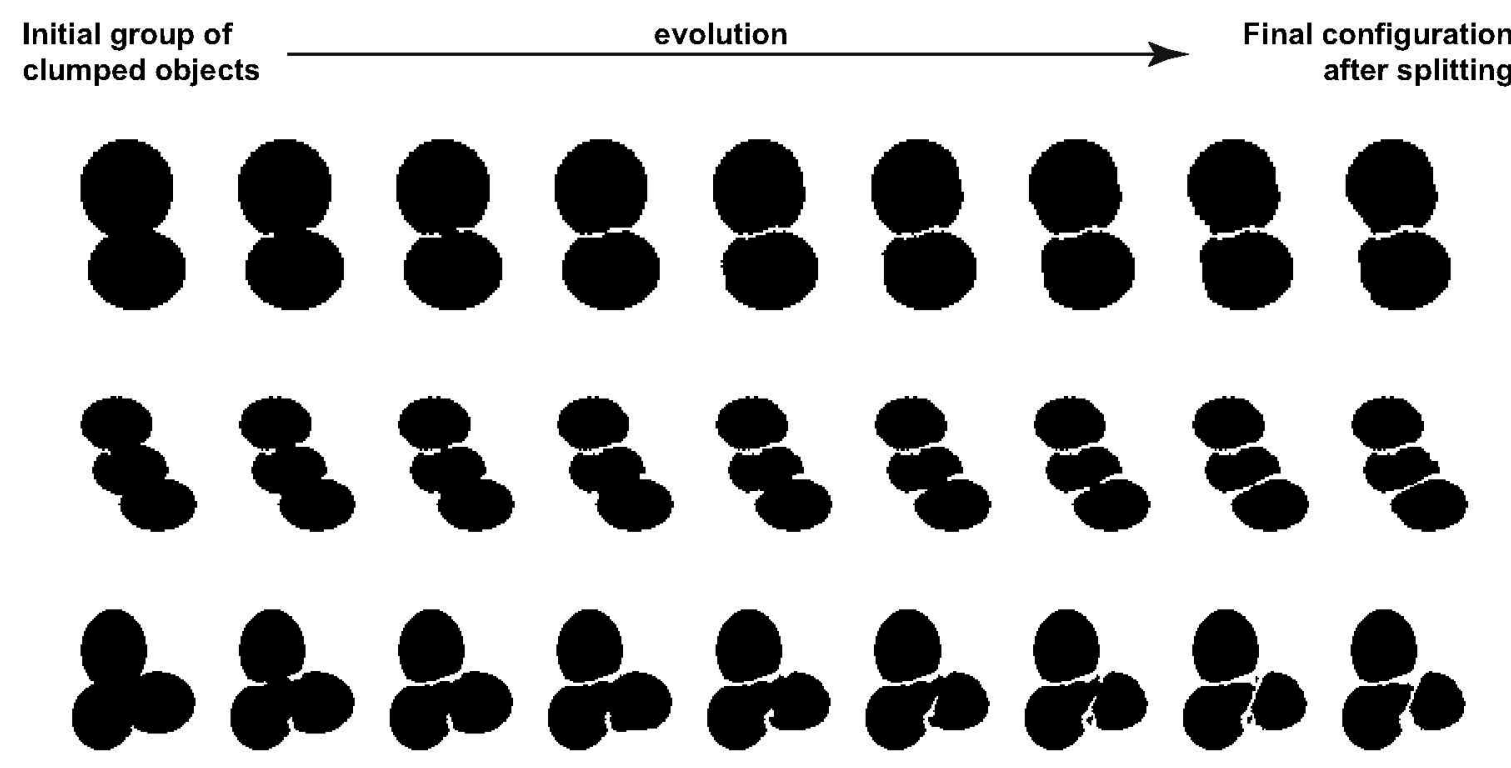

Figure 5.3: Behaviour of the geometric splitting model on different initial shapes.

The synthetic data set was created using the SIMCEP simulation tool [78] designed to test and evaluate image analysis methods for fluorescent microscopy. 60 images were generated each containing 20 nuclei of similar sizes and clustering into 3-5 clusters. A slight, maximum 5\%, overlap was allowed between individual cells. The method was compared to the widely used watershed method. Intensity- and shape-based peak detection was used to identify the individual objects in the aggregations [89]. To evaluate the segmentation quality of the proposed method and to compare it to others we used three metrics that were proposed in previous chapters. To analyze segmentation accuracy at the object level we calculated precision and recall values. Precision is the ratio of true positives (TP) relative to the number of detected objects (Precision $=\mathrm{TP} /(\mathrm{TP}+\mathrm{FP})$ ), while recall (or sensitivity) is the proportion of the objects of interest found (Recall = $\mathrm{TP} /(\mathrm{TP}+\mathrm{FN}))$. Values close to 1 represent a more accurate detection. First, matching between the ground truth and the set of segmented objects was executed. TP is the number of segmented objects with a matching ground truth object, while FP is the 
number of segmented objects that have no matching ground truth object. FN is the number of ground truth objects that have no matching segmented object. The third metric was the Jaccard-index for pixel-level accuracy, a similarity measure between sets: $\mathrm{JI}(A, B)=|A \cap B| /|A \cup B|$, for each matched pair. Fig. 5.4 shows sample images of intensity-based (Fig. 5.4 upper left) and shape-based (Fig. 5.4 middle) methods and the results obtained using the proposed splitting model (Fig. 5.4 upper right). The 'cutting arms' splitting method exceeded the results of the classical watershed method, especially in terms of object detection rate (Recall), but also slightly at pixel level measurements.
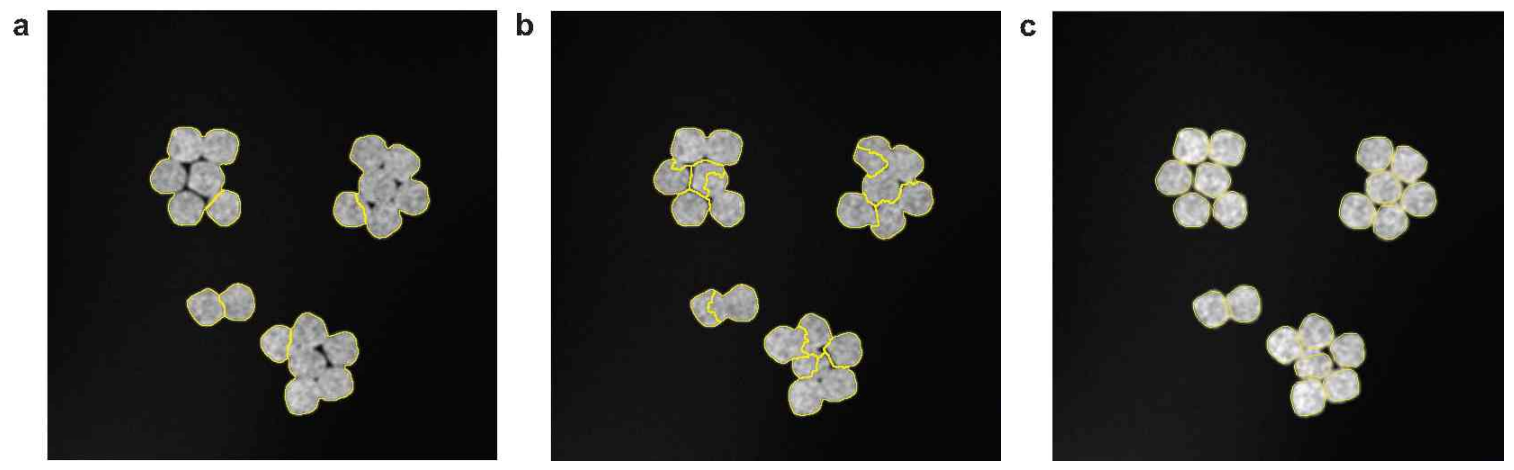

e

Segmentation results

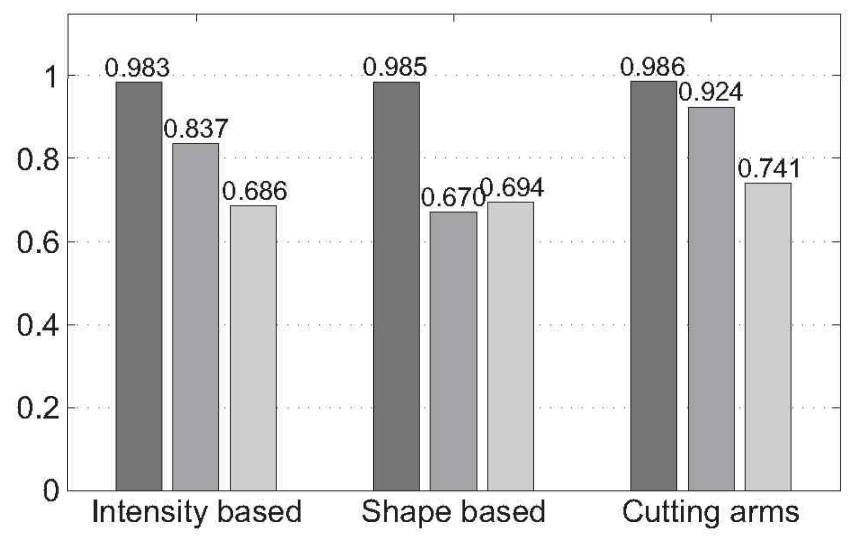

Precision (o) Recall (o) Jaccard index $(p)$

Figure 5.4: Results on simulated data. Upper row: (a) intensity-based watershed method, (b) shape-based watershed method; (c) results with the proposed method. Bottom plot: (e) precision, recall and Jaccard-index statistics of the methods.

Fig. 5.5 represents results obtained using the proposed method on real images of cancer cell cultures. The method was able to successfully identify single cells in this highly complex environment.

\subsubsection{Computational efficiency and implementation details}

The higher-order active contour models, by their nature and definition, require one order higher number of computations than the classical snakes. Even so, by collecting 


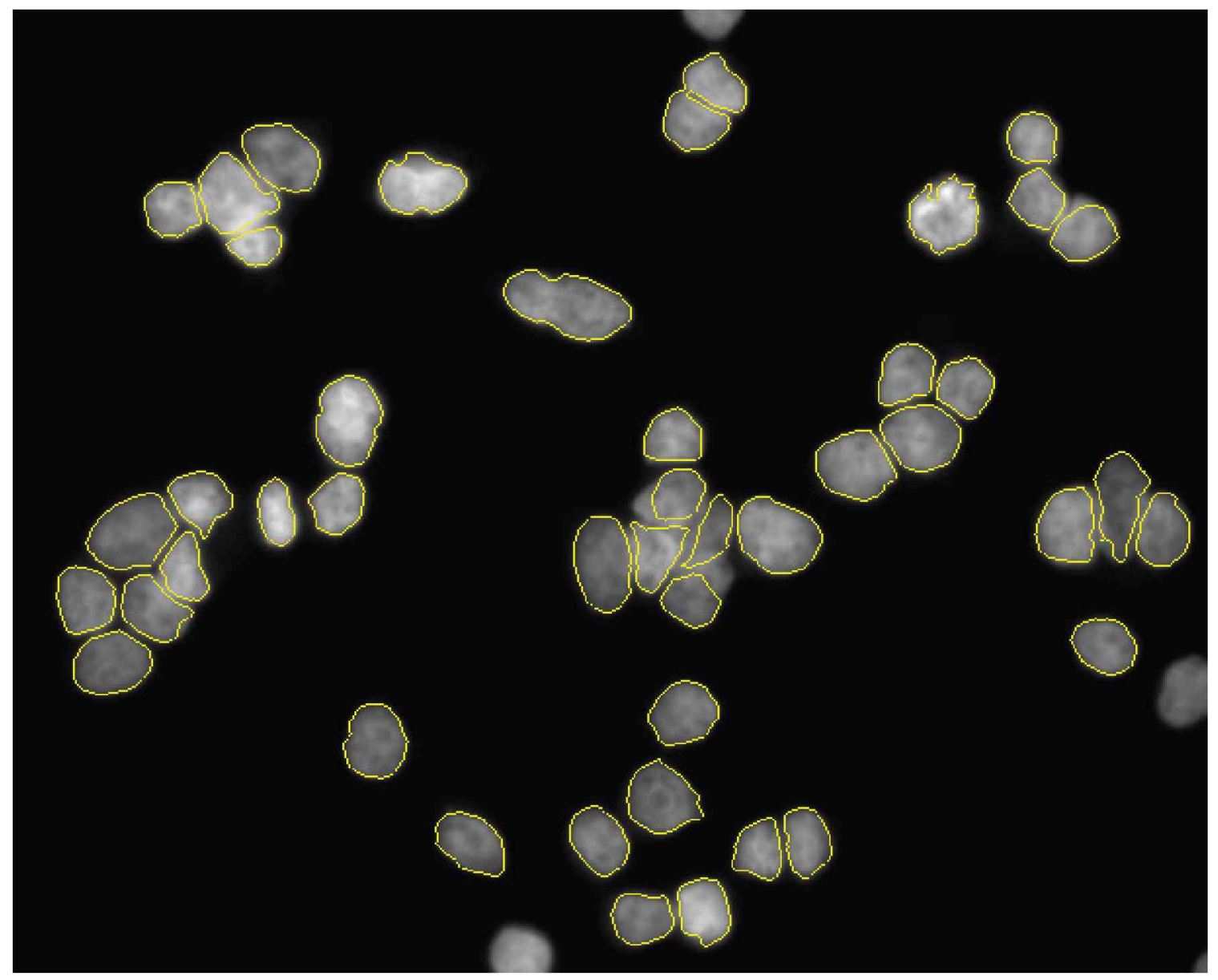

Figure 5.5: Sample results on real microscopic image data of cancer cells. 
the 'feasible subset' of the whole set of curve points highly reduces the actual number of calculations. During the evolution, the calculated derivatives are normalized per object to reach 'parallel' splitting, i.e. to avoid too slow motion of the curve if some of the other components cause high values for derivatives. Due to this parallelization, the splitting phase can be executed in less than one minute.

In case of an odd number of cutting arms, the final configuration will contain exactly one active arm. In this particular case this last arm starts to move towards the opposite side of the curve, which might not be necessarily concave. 



\section{Chapter 6}

\section{Applications}

As it has already been described in Chapter 1, segmentation is a crucial step in real computer vision applications. In difficult segmentation tasks it is important to utilize higher level prior knowledge about image structure, such as shape information of objects in the scene. In 'artificial scenes' it is more common to search for almost rigid shapes, such as rectangles (e.g. house walls, windows etc.), straight lines (e.g. roads in urban aerial images) etc, and finding some affine transformations of them is sufficient for further analysis. Methods that use template based approaches work efficiently in these applications. However, in applications which contain 'natural' objects, we need more precise shape models for numerous reasons. First, the objects that occur in nature usually cannot be captured by rigid shapes at all (e.g. human face, vasculature, nonurban aerial images etc.). Second, even if such objects can be approximated by rigid shapes, this way of segmentation is not precise enough for subsequent analysis (e.g. the morphology of cells is a crucial information about the cellular state). Therefore, it is not surprising that in processing of natural scenes, such as medical and biological research, deformable models (e.g. as variational methods) have become popular and widely used. The most commonly used variational methods, i.e. the active contour models and level sets have been successfully used in segmentation of organs, tissue parts, single cells or subcellular compartments even in case of poor imaging conditions.

The motivation behind this research is the precise and automatic segmentation of single cells or nuclei in case of difficult scenes such as highly dense images of cells. In these non-trivial cases it might be impossible to separate cells without shape information. The main applications of our shape modelling methods pertain to the field of high-throughput screening (HTS), as detailed below. By presenting possible and existing applications, we aim to place our new developments into workflows of image based biological research.

\subsection{High-throughput screening}

HTS allows a rapid acquisition of numerous images without human intervention. The term HTS usually refers to a joint cooperation between several science fields such as 
automated microscopy, fluorescence microscopy, biology, image processing and machine learning. Technological advances in automated microscopy now allow researchers to acquire images of thousands of different treatments, without human intervention and often over several days. Fluorescence microscopes are based on chemical compounds, called fluorophores, that re-emit light upon light excitation. They can be used alone, as a tracer in fluids, but more often they are used as a dye for staining certain structures. In the latter case fluorophores serve as markers of such structures, e.g. DNA (the most common case is nuclei staining), proteins, lipids or any other compartments inside and between the cells (Fig. 6.1, Fig. 6.2). This visualization of such tiny biological components enables us to capture and observe biological processes that were unable to be characterized before. All these above-mentioned developments have contributed to the rise of image-based cell profiling [1], which paves the way to large-scale studies of biological systems by using chemical and genetic perturbations.
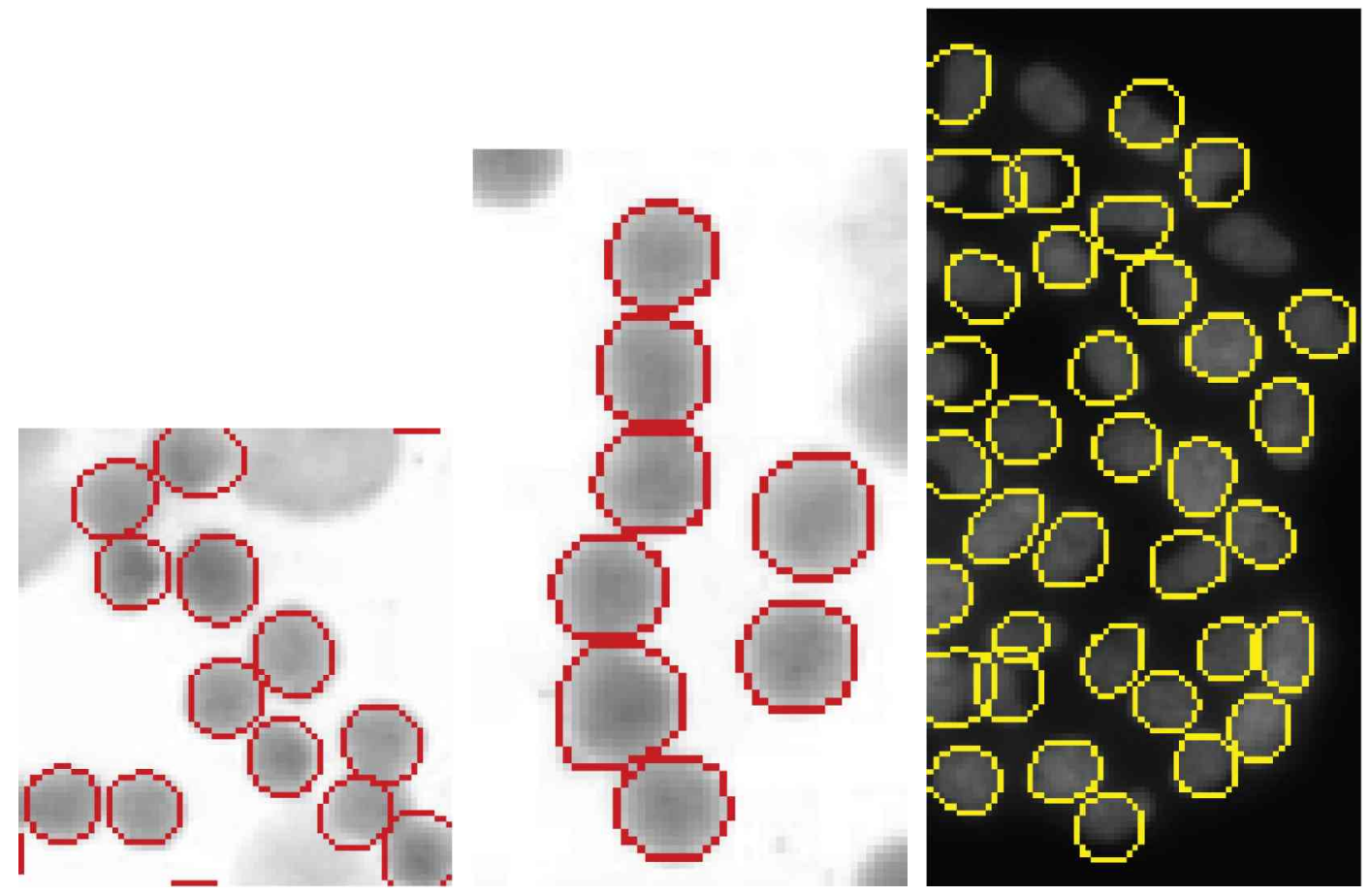

Figure 6.1: Data extraction from light microscope images of cells having a given radius.

Many advances in biology have also benefited from the exponential development of computer sciences and computing ability. Many advances in biology have also benefited from the exponential development of computer sciences and computing ability. Further increases in storage capacity, bandwidth and processing power are expected at a staggering rate. The main computational partner of computer-controlled microscope automation, however, is image analysis, which often receives less attention than it would deserve. The human brain took millions of years to evolve, and no doubt its analytical capabilities are superior to any artificial systems. Since the interpretation of visual scenes and images is so evident for us, often we do not consider it to be a difficult 

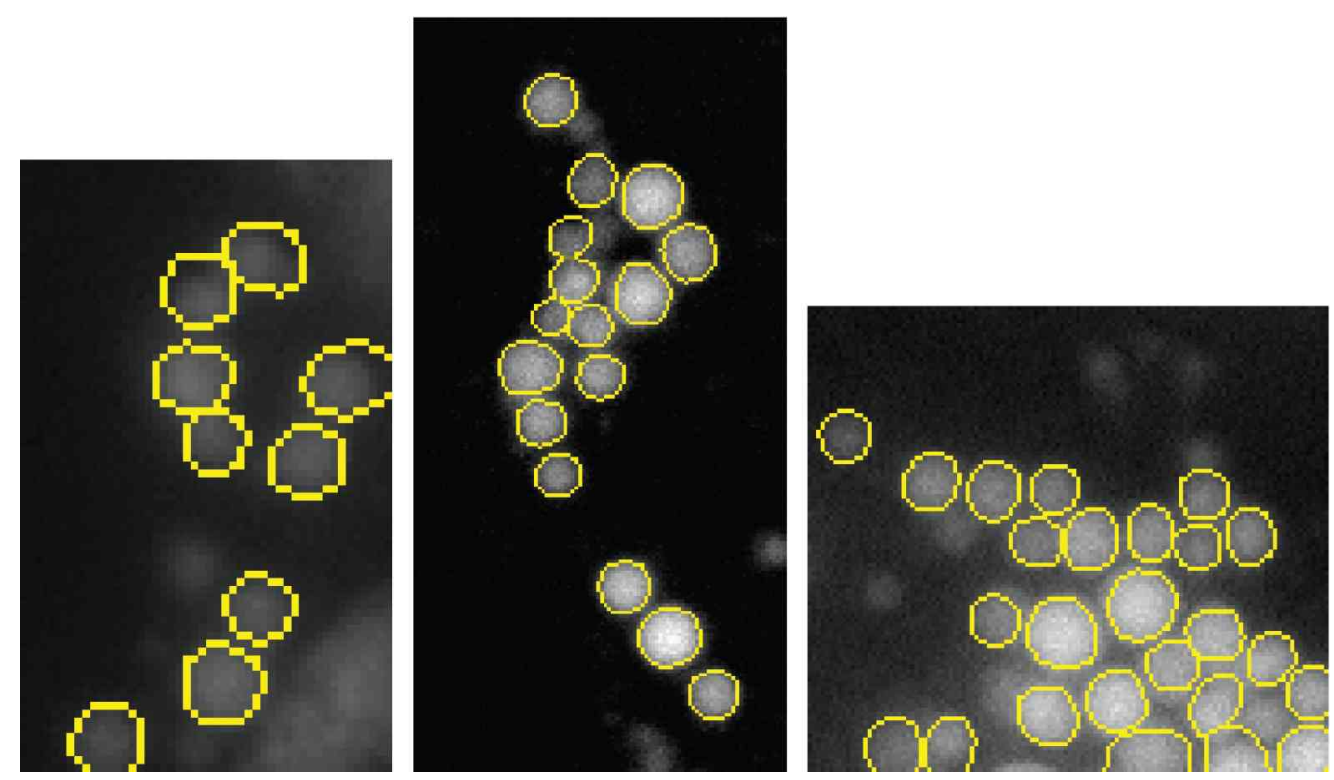

Figure 6.2: Segmentation of lipid droplets. The proposed MLGOC model can solve the extraction problem of touching objects.

task. Computers are still far from reaching our capacity to perceive and analyse images. However, they have much faster computational abilities and reliable precision over time than human resources. Therefore, there is an urgent need to improve computers to utilize 'smart' algorithms as pre-knowledge for the observed specimens.

Advances in computer hardware were not the only contributors to the development of HTS. Image-based screens are part of a bigger genomic revolution. In particular, the discovery of RNAi [90] and the availability of whole genome sequences allow the systematic knockdown of every gene or specific gene sets in a genome [91]. Of course, genome-wide RNAi screens are not the only application. The methodology needed for RNAi screens is similar to that required for image-based chemical screens to identify potential drug candidates [92].

In most HTS applications, a cell is the basic unit of analysis. For an extensive analysis of an experiment it is essential to measure various properties of each cell, such as shape (e.g. size, boundary) and the inner structure (e.g. intensity and texture). Thus, finding the cells and their precise boundaries within the image is inevitable. In image processing terms, this task is called segmentation. In most cases, the extraction of cells is executed in two steps: first, segmentation of the nuclei is required; next, cell body extraction is fulfilled, practically via an extension of nuclei segmentation.

High-resolution imaging has made it possible to count cells directly. In practice, manually identifying the positions and extracting the contours of millions of cells is prone to error and is highly time consuming. Thus, it is crucial to develop an automatic algorithm to detect and segment large numbers of cells. Many automated methods for detecting and segmenting isolated cells have already been developed, but 
these algorithms are not applicable to touching/overlapping cells. Other approaches have been proposed to address this specific issue. However, the automatic and precise segmentation of touching cells continues to be a major challenge for massive and highly complex datasets. For example, in case of tissue samples or cancer cell cultures one can frequently observe a high confluence of cells within the images.

In recent years, both the academic and the industrial sectors have been demonstrating increasing interest in developing more complex three-dimensional cell culture models. These can better capture the complexity of the tissue, and have the potential to provide more biologically relevant information than two-dimensional models. Conventional epifluorescence high-content microscope visualization is often used for shRNA, CRISPR-Cas9 and drug-screening of such 3D cultures. However, two-dimensional models are still more common than 3D models, but even in these simpler cases images may contain many overlapping cells/nuclei. Our research is aimed at the segmentation of images of such complex and inevitable cell configurations.

Cell counting 'Cell-based assays' (or 'cellular assays') are essential tools for HTS. They are used for screening collections of compounds to identify substances that alter the phenotype of cells. Of course, to answer simpler questions, such as the number of viable cells after an intervention, cell-based assays can also by utilized by other assay methods such as 'flow cytometry' or 'plate reader assays'. Both of these assay types can characterize very important cellular events, for instance cell viability or proliferation. Cell viability assays are suitable to determine the effects of drug candidates on cells by measuring the ratio of live and dead cells, i.e. the cytotoxicity of such compounds. Cell proliferation assays monitor the growth rate of cell populations under different treatment conditions, which rate describes the proper development and maintenance of the organism. Plate reader assays record an overall fluorescence intensity of each treated well, and cell viability is calculated as the comparison of this intensity to control wells. Flow cytometry is suitable for single cell fluorescent measurements, and it can be used for cell counting. However, plate reader assays are unsuitable for tissue-based experiments, and flow cytometry is not applicable for cell cultures of high confluence. HTS cell counting offers a solution that overcomes these limitations. Isolated cells in the image can be easily extracted by simple methods, such as thresholding. These simple methods give touching groups of objects that are not isolated as a result. We have developed a purely geometric active contour based variational model, the 'cutting arms' object splitting method, to count the number of cells more precisely via splitting these clumped object groups [87]. Our results show that this new splitting method gives more accurate results for nuclei separation, and thus for cell counting, than Voronoi tesselation or watershed based declumping methods that are commonly used in biology.

Cell segmentation and phenotyping Besides detecting each cell in the image, we aimed at executing a precise extraction of objects since the shape of the nuclei is an important descriptor of the cell [93]. In biological samples, many of these objects (e.g. nuclei, nucleoli) have a near-circular shape. This 'smart' pre-knowledge was described by one of our variational methods. These methods, i.e. the active contour models 
in our case, have the advantage over the classical template based methods in terms of segmentation of objects of a certain shape: namely, they can easily handle small perturbations over the object boundary. Therefore, they preserve more of the objects' original morphology. The multi-layered extension of the 'gas of near-circles' (MLGOC) model proved to be effective in segmentation of touching nuclei/cells. The additive data model for fluorescence microscopy was able to capture a common phenomenon of epifluorescence microscopy, namely that the measured intensity of overlapping objects is proportional to the number of these overlapping objects $[74,75]$. The results show that the geometric multi-layered model combined with the additive data model gives accurate segmentation of cell nuclei on real noisy and blurred images with low contrast acquired by light microscopy. The model was used for yeast cell segmentation as the first step of image based phenotyping of cells in genome-wide screens [94].

In order to achieve a faster segmentation while maintaining the shape selectivity of the active contour models, we have developed the selective active models which are able to describe the shape of an object by calculating computationally cheap descriptors [88]. The computational need of the selective active contour model is one order of magnitude less than that of the GOC model, and it is applicable not only for circular, but also for elliptical or plasma-like shapes too. This allows us to accurately segment a wider range of biological objects such as bacteria. The implementation of these methods is fully compatible with the additive data model for overlapping objects.

As our test results have shown, a well-chosen presegmentation step as initialization improves the accuracy and required running time of variational models (e.g. active contours). Detection of objects, which is different from segmentation, is employed as a first step of many object boundary extraction methods. It usually provides initial seeds of the final objects of interest by marking the center or a small inner region of the whole object. The previously mentioned 'cutting arms' object splitting model can be used for the detection of touching objects when no image information is given between adjacent objects, and furthermore, it gives a quite accurate segmentation of clumped objects by splitting object groups [87].

Strictly speaking, the mainstream analysis of HTS applications is out of the scope of this thesis, however, phenotyping, the central element of them, is strongly connected to the applications of our methods.

We have developed Advanced Cell Classifier (ACC) ${ }^{1}$, a graphical software package for quick and complex analysis of large-scale HTS experiments [95]. The user-friendly interface assures that even researchers without a machine learning background can interpret experimental data properly. Several methods are included to enhance the efficiency of the analysis: (1) active learning based cell annotation to achieve more accurate classification results; (2) find similar cells feature to annotate cell types which are already found but might be rare, and it can be done in batch mode; (3) phenotype finder to discover unseen phenotypes.

ACC is expected to be used widely, and therefore it must be compatible with other commonly used software in the field. For the preceding steps, such as segmentation

\footnotetext{
${ }^{1}$ http://www.cellclassifier.org/
} 
and feature extraction, CellProfiler [89] is the most common tool in biology. The features of single cells can be exported from CellProfiler to the input format of ACC. Proper extraction of important shape features requires an accurate segmentation, which can be executed by e.g. our MLGOC model. To make sure that our methods are easy-to-use tools for sophisticated cell-based image analysis, we have implemented our MLGOC shape models as CellProfiler modules. The related modules (e.g. cell body segmentation, feature extraction) had to be extended to properly handle multi-layered segmentations. The source code of all necessary modules are freely available: Matlab version for CellProfiler $1.0^{2}$ and Python version for CellProfiler $2.2^{3}$.

\subsection{Single cell isolation}

By incorporating our methods and tools developed for HTS data analysis, we have built an intelligent image-based in-situ single cell isolation system [96].

Much of our current understanding of biology is built upon population-averaged measurements, including many models for cellular networks and signalling. However, measurements averaging the behaviour of large populations of cells can lead to false conclusions if they mask the presence of rare but critical subpopulations. It is now well recognized that heterogeneities within a small subpopulation can carry important consequences for the entire population. For example, genetic heterogeneity plays a crucial role in drug resistance and the survival of tumours. Even genetically homogeneous cell populations possess large degrees of phenotypic cell-to-cell variability due to individual gene expression patterns. To better understand biological systems with cellular heterogeneity, we increasingly rely on single-cell molecular analysis methods. However, single-cell isolation, the process by which we target and collect individual cells for further study is still technically challenging and lacks a perfect solution.

We have developed a technique to increase the accuracy and throughput of microscopybased single-cell isolation by automating the target selection and isolation process. Computer-assisted microscopy isolation (CAMI) combines image analysis algorithms, machine learning, and high-throughput microscopy to recognize individual cells in suspensions or a tissue, and automatically guide extraction through laser capture microdissection (LCM) or micromanipulation.

A number of isolation methods are capable of collecting cells based on certain singlecell properties in a high-throughput manner, including fluorescence-activated cell sorting (FACS), immunomagnetic cell sorting, microfluidics, and limiting dilution. However, these harvesting techniques disrupt and dissociate the cells from the microenvironment, and they are incapable of targeting the cell based on location within the sample or by phenotypic profile. In contrast, micromanipulation and LCM are microscopy-based alternatives that directly capture single cells from suspensions or solid tissue samples. They can target cells by location or phenotype, and this contextual information can provide important insights when interpreting data from genetic analysis.

${ }^{2}$ https://bitbucket.org/csmolnar/mlgoc_cellprofiler_module

${ }^{3}$ https: / bitbucket.org/csmolnar/mlgoc_cellprofiler2_module 
The MLGOC model combined with the new additive model had an important role in this single cell isolation system. It was developed by the BIOMAG research group in the Biological Research Centre of the Hungarian Academy of Sciences in Szeged [96]. Since CellProfiler, an open source software for batch analysis of microscopic images, is widely used all over the world, we wrapped the Matlab implementation of the whole MLGOC model into CellProfiler modules. Note that we had to extend the original preand postprocessing modules to deal with multi-layered segmentation, i.e. a set of binary images as an output of the segmentation. This method allowed us to reliably identify cells with overlapping nuclei, which are typically discarded from molecular analysis to avoid contamination of untargeted cells (Fig. 6.3).

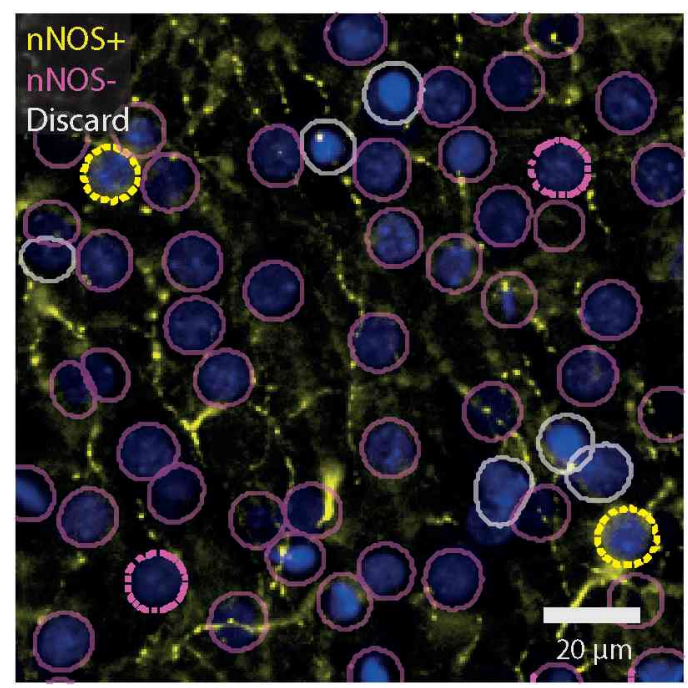

Figure 6.3: Segmentation by the MLGOC model and classification by ACC. Overlapping cells are discarded to avoid contamination.

Images from the microscope are sent to our image analysis software which uses stateof-the-art algorithms to correct illumination, to identify and segment cells (even in cases of overlap, thanks to the MLGOC model), and also to extract multi-parametric cellular measurements. The Advanced Cell Classifier software [95] trains machine learning algorithms to automatically recognize the cellular phenotype of every cell in the sample based on their extracted properties, and this data information, along with the location and contour of each cell, is sent to our interactive online database CAMIO (Computer aided microscopic isolation online, Fig. 6.4), an online single-cell data repository and selection tool we have developed. CAMIO provides an interface to approve the cells chosen to be extracted. If the user wishes, he/she may add or remove cells, or correct mistakes in the contour and in the classified phenotype. Selected cells are then extracted by micromanipulation or laser microdissection combined with a catapulting system.

These processes assure a non-disruptive collection of individual cells from fixed tissue or cell culture samples, and also the selection of cells based on phenotypic morphology or location within the tissue. The throughput, precision, and versatility of CAMI enables 
new modes of highly reproducible molecular analysis.

As cell phenotype predictions are ranked by confidence, 200 cells with the highest confidence for the interneuron and pyramidal phenotype classes were automatically uploaded to CAMIO. The purpose of this tool is to visualize individual cells and facilitate the selection of appropriate candidates for isolation. Individual cells are displayed, and organized by experiment and phenotypic classes. Cells can be selected for isolation automatically or through manual verification. Selected cells are sent instantly to the single-cell isolation device. The CAMIO interface allows the user to verify and correct the proposed cutting regions for each cell. It also records the location of the etched landmark relative to each object. The cell view of CAMIO interface is shown in Fig. 6.4, and a read-only version of the system can be tested online ${ }^{4}$. The software components we have developed to support this technology are freely available.

This work targeted several areas of high-throughput microscopy:

- We developed several segmentation methods for accurate and precise boundary extraction of objects in biological samples, and focused especially on high density images.

- We developed a user-friendly, smart and fast framework for analyzing and isolating hundreds or thousands of cells per day.

\footnotetext{
${ }^{4}$ https: / camio-webapp.herokuapp.com/
} 


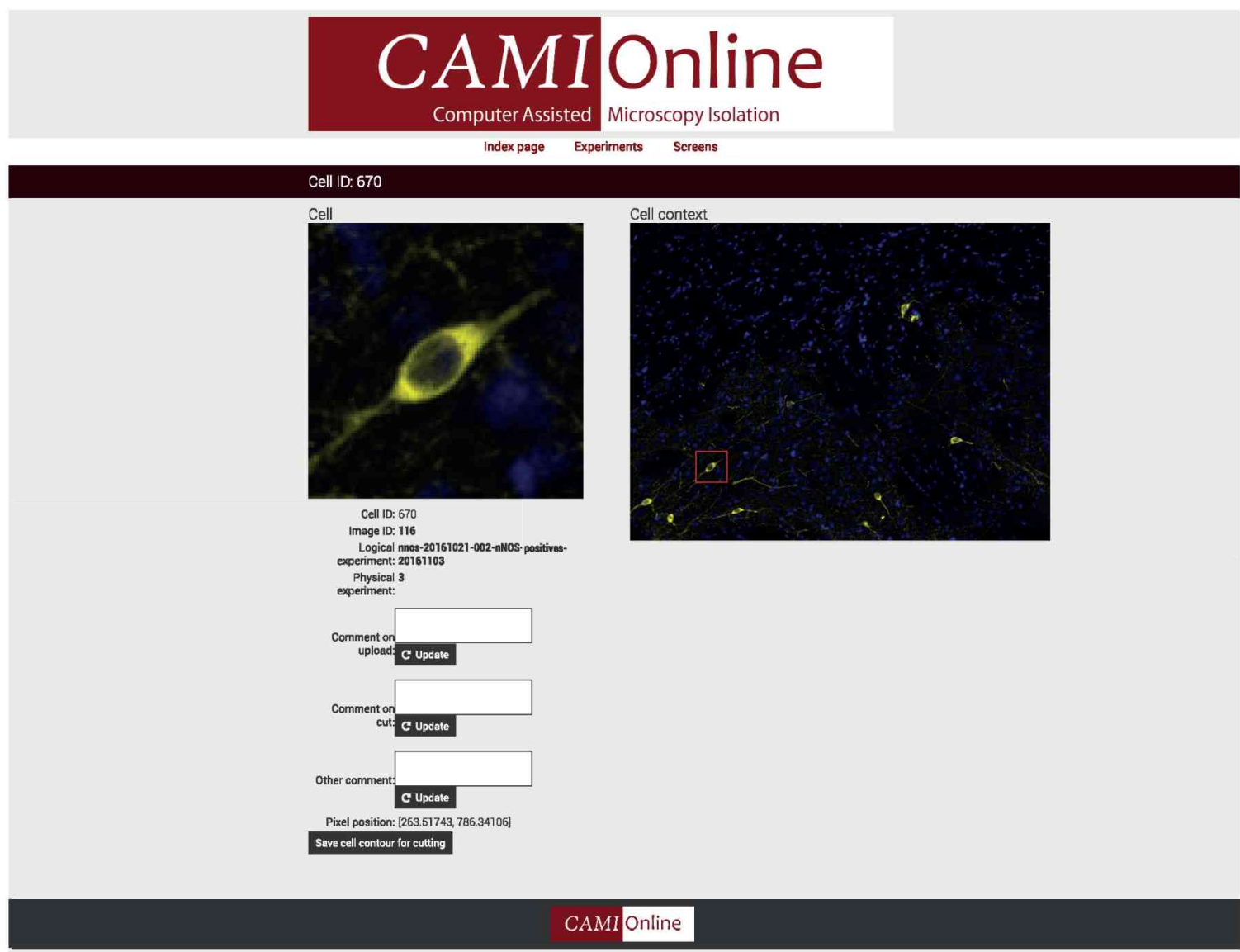

Figure 6.4: Cell view of CAMIO database. 



\section{Chapter 7}

\section{Conclusions}

In this section we summarize the main results of our research, and also re-state the aims and methods of our work.

\section{Summary}

Unprecedented advances in gathering and storing digital information have fuelled the need for computer-based, fast and reliable processing of digital images to explore meaningful information from these complicated and heterogeneous image data. For example, in life sciences, advancements in microscopy offer novel opportunities for a never-seen in-depth and detailed analysis of biological systems, however, exploring this plethora of information requires an automated processing of tens of thousands of images. Image segmentation is a key first step of image processing, during which visual objects (regions, shapes) are extracted from the images. However, efficient and precise image segmentation often requires prior knowledge on the objects in the images. Our research has focused on the development of novel image segmentation algorithms that exploit the objects' shape characteristics as a priori knowledge. During the development of these new segmentation algorithms, we aimed to preserve the original morphologies of the objects present in the images, as morphology often carries key information on the object itself. Taking these criteria into consideration, we have developed several variational methods which are suitable to segment an unknown number of objects with well-defined morphological characteristics present in the image. We focused on analysing images where the objects are densely packed.

The first third of the current thesis gives a solution for the segmentation of objects that are touching or even overlapping. We have extended the existing 'gas of nearcircles' (GOC) phase field model, which can extract near-circular objects, to a multilayered model. By using multiple layers of the original GOC model, we could describe overlapping objects. This way the repulsive forces, which prevent the objects from moving too close to each other, do not act between the layers. To avoid degenerate configurations we have added an extra energy term that penalizes overlapping.

The template based models (e.g. marked point processes or some of the active contour models), which have been developed to solve the same problem, try to fit rigid 
objects and their transformed versions to the image data. However, real life objects rarely can be covered by artificial predefined patterns or templates. The geometric prior in the HOAC models, which is the near-circular shape in our case, is preferred by higher-order active contour energies, which do not require any template shapes. This beneficial property of HOAC allowed us to achieve a more accurate and morphology preserving segmentation of the objects.

The multi-layered model inherited another main advantage of the single layer phase field model. The growing number of objects has no negative influence on the complexity of the calculations since the objects are implicitly defined by the actual phase field level set function in each iteration of the optimization process. We should note that the density of the objects within the image does, however, affect complexity. Denser images require more layers of the GOC model to get configurations in which spatially close objects appear on different layers without merging during the optimization. Experience has shown that a maximum of 4 layers is usually enough to properly handle configurations of even the highest density.

We have constructed a data model for fluorescent microscopy, and have combined it with the MLGOC phase field model. In this data model we have assumed that the intensity of overlapping objects is an additive function of the intensity of single objects. The combination of the MLGOC model and the additive data model showed high robustness against noise, shape deformations, initialization and the overlap level of the objects.

In the second part of the thesis, we have introduced a computationally effective active contour model that describes shapes by using only line integrals over object boundaries. We have introduced energy functionals that are composed of a size and a shape term. By using simple shape descriptors, such as area and perimeter of an object, we could selectively segment circular, elliptical or plasma-like shapes. In addition, we added a smoothness term to supplement the selective model. It was necessary to ensure a stable evolution of the curves. Since each term included in the selective active contour energy requires computations proportional to the contour length, fast optimization was achieved. Although the computational need of each term is linear in contour length, the order (or the dimension) of the quantities may differ. To balance the three terms in the energy functional we derived their normalized form, which provides dimensionless quantities. This way we could fix the inner weights of the geometric prior once and for all. We have combined the selective model with a scalable region-based data model to test it on synthetic and real images. Similarly to the GOC model, we have extended the level set version of the selective active contour to a multi-layered model. We have also successfully combined the multi-layered selective active contour model with the additive data model.

Finally, in the last part of the thesis, we have presented a new higher-order active model for object splitting, called the 'cutting arms' model. This purely geometric model is able to cut clumped objects by connecting opposite concave points of the object group's boundary. The 'cutting arms' HOAC model moves only a restricted subset of the contour points, the so-called 'feasible subset', so the cutting process is computationally inexpensive. The model offers an alternative for splitting object groups into single 
objects in those cases when the image data do not provide enough edge information to separate these objects. The results have shown that the new HOAC model outperforms the classical methods which are commonly used for splitting (e.g. Voronoi diagram or watershed based methods).

Fig. 7.1 shows the logical connection between geometric and data models we have developed, depicted as a flowchart grouped by the sections of the thesis and the corresponding publications.

\section{Limitations/Unsolved issues}

We report different types of issues that have occurred during our research work. A common limitation of each model we have developed is that they are very sensitive to initialization due to gradient descent optimization. As it was shown, acceptable segmentations can be achieved by starting from a 'primitive' but cheap initialization, such as Gaussian white noise for the phase field implementation or square-shaped initial contour for the selective model. However, the accuracy of the segmentation and the speed of the curve's convergence can be improved by some preprocessing steps, such as seed detection or thresholding segmentation. This is increasingly true for the objects splitting contour. 'The correct extraction of the 'feasible subset' from the contour points highly depends on the first phase of segmentation since only the boundary points with a high negative curvature affect the splitting phase of the segmentation. We recommend to apply a computationally cheap preprocessing step before using our proposed methods to get much faster and more accurate results.

Our models have specific shortcomings that also need to be addressed. The GOC model prefers circles as a stable state of the HOAC energy. The cell nuclei, however, may have a shape different from the perfect circle. It is possible to allow a higher level of elongation than it was experimentally determined during our tests. After the expansion of the HOAC energy to the second order, we have to restrict the HOAC parameters demanding that the second order term $\left(E_{2}\left(r_{0}, k\right)\right)$ be negative in the case of $k=2$. If we keep the first order term at zero, we will have an extremum of the energy at a perfect circle, but a slight elongation of the circle could decrease the energy.

In the normalized equations of the selective active contours, which give dimensionless quantities, the inner weights of the size, shape and smoothness terms were determined empirically. If it is possible, it will be a more elegant manner to calculate (or estimate) the inner weights of the geometric model using an analytical approach. The stability analysis of the selective contour's energy functional might give restrictions on the parameters without gathering empirical measurements.

\section{Future directions}

The potential for developing variational models is still significant in image processing. Our research also raises several directions to follow. One direction can be the development and definition of new data models to supplement the existing shape models. 


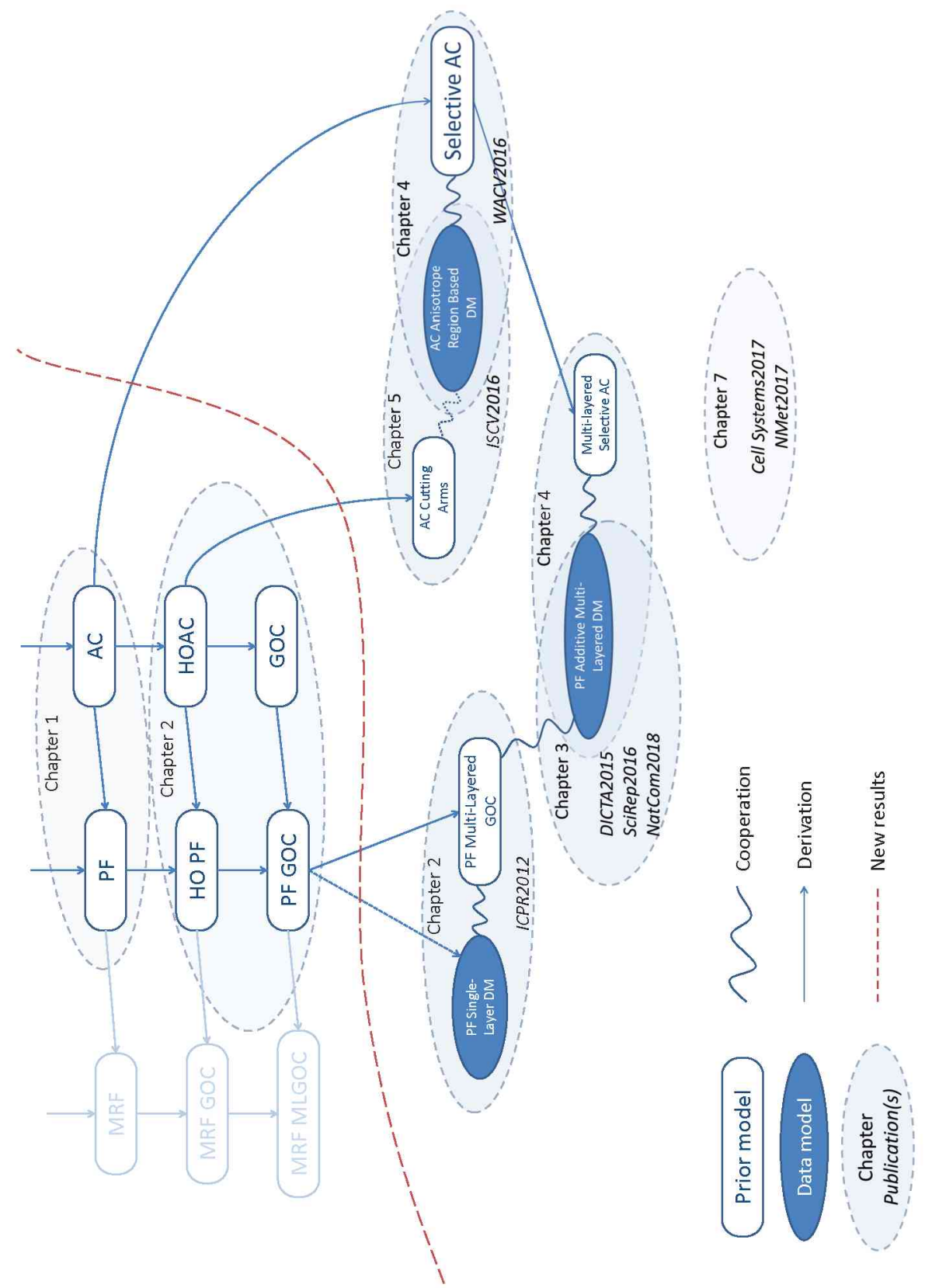

Figure 7.1: Connections between used and developed models. The methods we have developed are shown below the red curve. AC: active contour model; PF: phase field model; HOAC: higher-order active contour model; HOPF: higher-order phase field model; GOC: active contour 'gas of near-circles' model; PFGOC: phase field 'gas of near-circles' model; (MRF: Markov random field model). 
Implementation of the developed active contour based shape models into different model frameworks can be another route to continue our research. The most interesting direction could be the extension of the $2 \mathrm{D}$ shape models into three-dimensional ones. The second and third directions raise another interesting point, that is how the methods and algorithms could be optimized by parallel computations in a very fast way.

The multi-layered models, both the MLGOC and the multi-layered selective active contour models, can be combined with data models other than those presented in this work. For confocal imaging one can define a data model which is not based on an additive function of the independent layers, but on their union instead. Since in confocal microscopy a stack image of a sample is the image of sample slice of almost zero thickness, overlapping is not visible between the observed objects. However, the problem of touching objects is also presented in this imaging modality, and thus the application of multi-layered extensions of our active contour models is still justified. In several applications the image gradient could improve segmentation accuracy. However, for the multi-layered models it was not taken into account in our calculations.

The phase field representation of the selective and cutting active contour models can increase the power of these models. As it was shown, the phase field representation of the same active contour based shape model boosted the optimization speed and decreased dependency on initialization. The Markov random field (MRF) models have also become useful in image processing. The proper discretization of the phase field models can be formulated in appropriate MRF models. The MRF models are based on robust stochastic methods. They are usually solved by simulated annealing, and thus they are more likely to find a solution closer to the global optimum.

Extending the 2D models for 3D segmentation is probably the most challenging, but at the same time, the most important direction of research to follow. The analysis of 3D image data allows a deeper understanding of biological processes. As a result of recent advances in 3D imaging, there is pressing need for object extraction methods applicable for 3D data. Multi-layered models are meaningless in 3D image processing since in these cases there is no need to deal with the phenomenon of overlapping. However, the selective and the cutting active contour models have numerous possible applications in 3D. Fast processing of large amounts of 3D data, e.g. 100 stacks of $1000 \times 1000$ sized images needs $100 \mathrm{MB}$ memory, thus using GPU programming is suggested. The level sets can be naturally stored and distributed between the threads of the GPU. However, the extraction of the actual surfaces as connected components might generate difficulties. The components are needed for the calculation of the required quantities of energy functionals, but the method should utilize the advantages of parallel computing to find an efficient solution.

Thus, numerous possible directions of future progresses are inherent in our research field, giving room for further evolution of sophisticated 2D and 3D computational image analysis in life sciences. 



\section{Magyar nyelvü összefoglaló}

Ebben a fejezetben összefoglaljuk a jelen dolgozat főbb eredményeit, újra felsorolva a kutatásunk céljait és ezen célok eléréséhez kidolgozott módszereket.

\section{Összefoglalás}

A digitális információ gyưjitésének és tárolásának ugrásszerú fejlôdésével kiemelt fontosságú lett a digitális képek gyors és megbízható számítógépes feldolgozása a képi információk kinyeréséhez. Például az élettudományok területén a mikroszkópiai fejlesztések lehetôvé teszik a biológiai rendszerek eddig soha nem látott részletességú vizsgálatát, ami viszont képek tízezreinek automatikus feldolgozását igényli. A szegmentálás a legtöbb képfeldolgozási alkalmazás egyik legelsố, így kulesfontosságú lépése, amely során vizuális objektumokat (régiókat, alakzatokat) nyerünk ki a képekból. A hatékony és pontos szegmentálás eléréséhez azonban sok esetben szükség van elôzetes információkra is ezekrổ az objektumokról. A kutatómunkánk során olyan szegmentáló eljárások kifejlesztésével foglalkoztunk, amelyek a keresett objektumok alakját használják ilyen a priori információként. A modellek fejlesztése során a képeken található objektumok eredeti morfológiájának minél pontosabb megôrzésére törekedtünk, mivel az számos esetben fontos információt hordozhat az objektumról. A fenti kritériumokat figyelembe véve többféle variációs módszert is kidolgoztunk, amelyek alkalmasak ismeretlen számú, meghatározott alakjellemzőkkel rendelkezô objektum szegmentálására.

A dolgozat elsố harmadában egy olyan modellt mutattunk be, amely képes érintkezố vagy akár egymással átfedő objektumok szegmentálására. A meglévő "gas of nearcircles" (GOC) phase field modellt, ami körszerú objektumok kinyerését teszi lehetôvé, kiterjesztettük egy többrétegú modellé (multi-layer GOC model - MLGOC). Az eredeti GOC modell több példányát rétegekként használva átfedő objektumokat is reprezentálhatunk. Az objektumok között fellépő taszító erônek, ami megakadályozta, hogy az objektumok közel kerüljenek egymáshoz, nincs hatása különbözô rétegeken reprezentált objektumok között, így ennek negatív hatása kiküszöbölhetô. A szélsôséges konfigurációk elkerülése érdekében egy olyan extra tagot is hozzáadtunk az energiafüggvényhez, ami a rétegek között fejti ki a hatását és bünteti az átfedô területek kialakulását.

A objektum sablonokat használó modellek, amelyek ugyanerre a jellegú problémára keresnek megoldást, merev alakzatokat vagy azok transzformált verzióit próbálják a képi adatra illeszteni. Sajnos a valós objektumok ritkán fedhetôk le pontosan mesterséges sablonokkal vagy minta alakzatokkal. A magasabb rendú aktív kontúr modellek 
(higher-order active contours - HOAC) a geometriai priort, ami esetünkben a körszerú alak, magasabb rendú integrálokkal írják le, így nem igényelnek semmilyen referencia objektumot. A HOAC modellek ezen elönyös tulajdonsága lehetôvé teszi az objektumok pontosabb, a morfológiát jobban megôrzố szegmentálását.

Az új többrétegú modell az eredeti phase field modell egy másik elônyös tulajdonságát is örökölte: az objektumok növekvố száma nem növeli a modell számítási bonyolultságát, mivel a phase field level set függvény az optimalizálás minden pillanatában implicit meghatározza az objektumokat, így azok tárolására nincs szüikség. Fontos megjegyezni azonban, hogy az objektumok térbeli sưrúsége a képen ugyakkor hatással van a számítási komplexitásra. A sürúbb konfigurációk esetén több réteggel kell dolgoznunk annak érdekében, hogy a képen közel lévô objektumok különbözô rétegekre kerülhessenek elkerïlve azok esetleges összeolvadását az optimalizálás alatt. A kísérleteink során azt tapasztaltuk, hogy legfeljebb 4 réteg használata elegendố még a legsứrúbb konfigurációk esetén is.

Emellett kidolgoztunk egy új adatmodellt fluoreszcens mikroszkópokkal készült képekre, amelyet a többrétegú MLGOC phase field modellel társítottunk. Az említett adatmodellben kihasználtuk a képalkotás azon tulajdonságát, hogy az egymással átfedô objektumok intenzitását az egyes objektumok intenzitásának additív függvényével közelítjük. Az MLGOC modell az additív adatmodellel együtt alkalmazva robusztusnak bizonyult a zajjal, különbözô deformációkkal vagy az objektumok között megengedett átfedés mértékével szemben is, sôt továbbra sem volt sziukséges speciális inicializáció a jó eredmények eléréséhez.

A dolgozat második részében bemutattunk egy hatékony aktív kontúr modellt, amely az objektumok alakját olyan módon képes leírni, hogy csak vonalintegrálokat kell kiszámolnunk az objektumokat határoló körvonalon. Az aktív kontúr modellek energiáját egy méretet és egy alakot leíró tag bevezetésével alkottuk meg. Olyan egyszerú alakjellemzóket használva, mint például a kerület vagy terület, képesek voltunk szelektíven szegmentálni körszerú, ellipszoid vagy akár amöbaszerú objektumokat is. A konstruált energiafüggvényhez egy olyan kiegészítő tagot is adtunk, amely simító hatást eredményez. Ez utóbbira a kontúrok stabil mozgatásához van szükség. Mivel minden egyes energiatag kiszámítása a kontúr hosszával arányos, gyors optimalizálást tudtunk elérni. Habár az egyes tagok számításigénye lineárisan függ a kontúr hosszától, a kiszámolt mennyiségek rendje (vagy dimenziója) eltérhet egymástól. Az energiafüggvény három tagját ezért normalizáltuk az egyes tagoknak megfelelően. Az így kapott normalizált formában az energiatagok súlyát egymáshoz képest csak egyszer szükséges beállítani a geometriai priorban, amit késóbb nem kell módosítanunk más méretú objektumok esetén. A szelektív aktív kontúr modellt egy régió alapú adatmodellel egészítettiik ki, így teszteltiik a múködését mesterséges és valós képeken is. A GOC modellhez hasonlóan az új szelektív aktív kontúr modell level set implementációját is kiterjesztettük többrétegú modellé, majd ezt az additív adatmodellel együttmúködve is teszteltük.

Végül a dolgozat utolsó részében egy olyan magasabb rendú aktív kontúr modellt mutattunk be, az ún. "cutting arms" modellt, amely képes különálló objektumokra szétvágni az objektumesoportokat. Ez a tisztán geometriai információt használó modell 
úgy vág szét összetapadt objektumokat, hogy összeköti az objektumcsoport egymással szemben elhelyezkedô, konkáv határpontjait. A "cutting arms" magasabb rendú aktív kontúr modell csak a határpontok egy meghatározott, szúk részhalmazát mozgatja a vágási folyamat közben, így az hatékonyan végrehajtható. A modellt olyan esetekben is alkalmazhatjuk, amikor a képen nincs elegendô él információ az érintkezô objektumok szétválasztására. A teszteredmények alapján elmondhatjuk, hogy a "cutting arms" modell felülmúlja a széles körben használt klasszikus modelleket (pl. Voronoi diagram vagy watershed alapú módszerek).

A 7.1 ábrán szemléltetjük az általunk kifejlesztett geometriai és adatmodellek között fennálló kapcsolatokat. Az ábrán az egyes modelleket a dolgozat fejezetei és a született publikációk alapján esoportosítottuk.

\section{Jövőbeli kutatási irányok}

Variációs módszerek fejlesztésében még mindig nagy lehetőségek rejlenek a képfeldolgozás számos területén. Munkánk számos további kutatási irányt elôre vetíthet. Egy lehetséges irány lehet a kifejlesztett alakmodellek támogatása másfajta adatmodellekkel. $\mathrm{Az}$ itt leírt modelleket másféle keretrendszerben (pl. Markov véletlen mezókkel, Markov Random Fields - MRF) leírva hatékonyabb implementációt kaphatunk, így érdemes lenne további vizsgálatra. A téma egyik legérdekesebb és legígéretesebb folytatása a kétdimenziós alakmodellek kiterjesztése lenne 3D szegmentálásra. Ez a két utóbbi lehetséges folytatási irányvonal felvet egy másik érdekes gyakorlati kérdést: hogyan lehetne az algoritmusokat párhuzamos számításokkal felgyorsítani?

A jelen dolgozatban bemutatott többrétegú modelleket másféle adattagokkal is kombinálni lehet. Konfokális mikroszkópok esetén például olyan adatmodellt használhatnánk, ami az egyes különálló rétegek összegzése helyett azok speciális unióját használná. A konfokális mikroszkópok által alkotott kép a minta egy majdnem nulla vastagságú szeletéról képes képet készíteni, így átfedést, ahogy azt korábban tapasztaltuk, nem láthatunk a képen. Érintkezố objektumokkal azonban még mindig találkozhatunk ennél a képalkotási módszernél, így a többrétegú modellek alkalmazása ebben az esetben is hasznos eszköz lehet.

A szelektív és vágó aktív kontúr modellek phase field megfelelöje nagyban növelhetné a modellek erejét. Korábban már bemutatták, hogy aktív kontúr alakmodellek megfelelő phase field változatát használva nagymértékben felgyorsítható a szegmentálás, valamint csökkenthetô az inicializálás hatása a végsố eredményre. A képfeldolgozásban a Markov véletlen mezöket használó modelleket is széles körben alkalmazzák. A phase field modellek megfelelô diszkretizációjával a kifejlesztett modellek MRF formalizmussal felírható egyenértékú változatai is megadhatók. Az MRF modellek robusztus valószínúségi módszerekre épülnek. Általában szimulált hútéssel keresik a megoldásukat, ami azt jelenti, hogy globális megoldás keresésére alkalmasak.

Valószínúleg a modellek 3D-re való kiterjesztése jelentheti a legnagyobb kihívást, ugyanakkor ezek a fejlesztések mutatkoznak jelenleg a legfontosabb kutatási területeknek. Csak egy példát kielmelve, az élettudományok területén a háromdimenziós képek 
elemzése a biológiai folyamatok mélyebb megértését teszi lehetôvé. A 3D képalkotás legújabb vívmányai maguk után vonják a megfelelő algoritmusok fejlesztésének szükségességét. A többrétegú modellek alkalmazása három dimenzióban értelmét veszti. A szelektív és a vágó aktív kontúr modelleknek viszont számos alkalmazási lehetôsége van 3D-ben is. A 3D adatok gyors feldolgozására a modellek GPU implementációja javasolt. A level set függvények természetesen tárolhatók és szétoszthatók a GPU munkaszálai között. Az aktuális felületek és a kapesolódó komponensek kinyerése viszont érdekes problémákat vethet fel. A kapcsolódó komponensek szükségesek az energiatagok kiszámolásához, viszont a hatékony implementációnak ki kell használnia a párhuzamos számítások adta elönyöket. 


\section{Appendix A}

\section{Functional derivative of overlap penalty term}

The total energy of the multi-layered phase field model is

$$
\tilde{E}_{f}(\Phi)=\sum_{i=1}^{\ell} E_{f, g}\left(\phi^{(i)}\right)+\frac{\kappa_{O}}{4} \sum_{i \neq j} \int_{\Omega}\left(1+\phi^{(i)}\right)\left(1+\phi^{(j)}\right)
$$

where $\Phi=\left\{\phi^{(i)}\right\}_{i \in[1 . \ell]}:[1 . \ell] \times \Omega \rightarrow \mathbb{R}$, where $\ell$ is the number of layers. We need to compute its functional derivative with respect to each phase field layer [69]:

$$
\frac{\delta \tilde{E}_{f}(\Phi)}{\delta \phi^{(k)}\left(x^{\prime}\right)}=\sum_{i=1}^{\ell} \frac{\delta E_{f, g}\left(\phi^{(i)}\right)}{\delta \phi^{(k)}\left(x^{\prime}\right)}+\frac{\kappa_{O}}{4} \frac{\delta E_{O}(\Phi)}{\delta \phi^{(k)}\left(x^{\prime}\right)}
$$

where $E_{O}(\phi)$ denotes the overlap energy term from Eq. (1). The first term is simply the functional derivative of $E_{f, g}$ evaluated at the $\phi^{(k)}$, and so is known [40, 41]. We expand the brackets:

$$
\begin{aligned}
E_{O}(\Phi) & =\frac{\kappa_{O}}{4} \sum_{i \neq j} \int_{\Omega}\left(1+\phi^{(i)}\right)\left(1+\phi^{(j)}\right) d x \\
& =\frac{\kappa_{O}}{4} \sum_{i \neq j} \int_{\Omega}\left(1+\phi^{(i)}+\phi^{(j)}+\phi^{(i)} \phi^{(j)}\right) d x \\
& =\frac{\kappa_{O}}{4}\left(\frac{\ell(\ell-1)}{2} \int_{\Omega} 1 d x+2(\ell-1) \sum_{i=1}^{\ell} \int_{\Omega} \phi^{(i)} d x+\sum_{i \neq j} \int_{\Omega} \phi^{(i)} \phi^{(j)} d x\right)
\end{aligned}
$$

Let $\delta_{i k}$ be $\frac{\delta \phi^{(i)}}{\delta \phi^{(k)}}$. This way the derivative of the overlap energy is 


$$
\begin{aligned}
\frac{\delta E_{O}(\phi(x))}{\delta \phi^{(k)}(y)} & =0+2(\ell-1) \frac{\sum_{i=1}^{\ell} \int_{\Omega} \delta(x, y) \phi^{(i)} d x}{\delta \phi^{(k)}(y)}+\frac{\left.\sum_{i \neq j} \int_{\Omega} \delta(x, y) \phi^{(i)} \phi^{(j)} d x\right)}{\delta \phi^{(k)}(y)} \\
& =2(\ell-1) \sum_{i=1}^{\ell} \delta_{i k}+2 \sum_{i \neq j} \delta_{i k} \phi^{(j)} \\
& =2(\ell-1)+2 \sum_{j \neq k} \phi^{(j)} .
\end{aligned}
$$

\section{Functional derivative of image data term}

First we tried to compose the meta phase field $\widetilde{\phi}_{+}$by simple addition of the independent phase field layers. Let $\phi=\sum_{i=1}^{\ell} \phi^{(i)}$ and $\tilde{\phi}_{+}=\sum_{i=1}^{\ell} \frac{\left(\phi^{(i)}+1\right)}{2}$, where $\phi^{(i)}$ is the phase field in the $i^{\text {th }}$ layer. The proposed data term is:

$$
E_{\text {intensity }}\left(I, \phi_{+}\right)=\gamma_{d} \int_{\Omega} \frac{\left(I-\mu_{-}-\Delta \mu \tilde{\phi}_{+}\right)^{2}}{2\left(\sigma_{-}^{2}+\Delta \sigma^{2} \tilde{\phi}_{+}\right)} d x
$$

where $\mu_{-}$and $\sigma_{-}^{2}$ is the mean and variance of the background intensity, and $\mu_{+}$and $\sigma_{+}^{2}$ is the mean and variance of the measured intensity of a single cell; $\Delta \mu=\mu_{+}^{2}-\mu_{-}^{2}$, and $\Delta \sigma^{2}=\sigma_{+}^{2}-\sigma_{-}^{2}$. The parameters $\mu_{-}, \sigma_{-}^{2}, \Delta \mu$, and $\Delta \sigma^{2}$ are estimated from the corrected images using maximum likelihood estimation.

Let's calculate the derivative by definition:

$$
\begin{aligned}
\delta E_{\text {intensity }} & =E_{\text {intensity }}\left(\tilde{\phi}_{+}+\delta \tilde{\phi}_{+}\right)-E_{\text {intensity }}\left(\tilde{\phi}_{+}\right) \\
& =\frac{\gamma_{d}}{2} \int\left[\frac{\left(I-\mu_{-}-\Delta \mu\left(\tilde{\phi}_{+}+\delta \tilde{\phi}_{+}\right)\right)^{2}}{\left(\sigma_{-}^{2}+\Delta \sigma^{2}\left(\tilde{\phi}_{+}+\delta \tilde{\phi}_{+}\right)\right)}\right. \\
& \left.-\frac{\left(I-\mu--\Delta \mu \tilde{\phi}_{+}\right)^{2}}{\left(\sigma_{-}^{2}+\Delta \sigma^{2} \tilde{\phi}_{+}\right)}\right] d x \\
& =\frac{\gamma_{d}}{2} \int\left[\frac{\left(I-\mu_{-}-\Delta \mu\left(\tilde{\phi}_{+}+\delta \tilde{\phi}_{+}\right)\right)^{2}\left(\sigma_{-}^{2}+\Delta \sigma^{2} \tilde{\phi}_{+}\right)}{\left(\sigma_{-}^{2}+\Delta \sigma^{2}\left(\tilde{\phi}_{+}+\delta \tilde{\phi}_{+}\right)\right)\left(\sigma_{-}^{2}+\Delta \sigma^{2} \tilde{\phi}_{+}\right)}\right. \\
& \left.-\frac{\left(I-\mu--\Delta \mu \tilde{\phi}_{+}\right)^{2}\left(\sigma_{-}^{2}+\Delta \sigma^{2}\left(\tilde{\phi}_{+}+\delta \tilde{\phi}_{+}\right)\right)}{\left(\sigma_{-}^{2}+\Delta \sigma^{2}\left(\tilde{\phi}_{+}+\delta \tilde{\phi}_{+}\right)\right)\left(\sigma_{-}^{2}+\Delta \sigma^{2} \tilde{\phi}_{+}\right)}\right] d x \\
& =\frac{\gamma_{d}}{2} \int\left[\frac{\Delta \mu^{2} \Delta \sigma^{2} \tilde{\phi}_{+}^{2}+2 \Delta \mu^{2} \sigma_{-}^{2} \tilde{\phi}_{+}-\Delta \sigma^{2}(I-\mu-)^{2}-2 \Delta \mu \sigma_{-}^{2}\left(I-\mu_{-}\right)}{\left(\sigma_{-}^{2}+\Delta \sigma^{2} \tilde{\phi}_{+}\right)^{2}+\delta \tilde{\phi}_{+} \Delta \sigma^{2}\left(\sigma_{-}^{2}+\Delta \sigma^{2} \tilde{\phi}_{+}\right)}\right. \\
& \left.-\frac{\Delta \mu^{2} \Delta \sigma^{2} \tilde{\phi}_{+}+\Delta \mu^{2} \sigma_{-}^{2}}{\left(\sigma_{-}^{2}+\Delta \sigma^{2} \tilde{\phi}_{+}\right)^{2}+\delta \tilde{\phi}_{+} \Delta \sigma^{2}\left(\sigma_{-}^{2}+\Delta \sigma^{2} \tilde{\phi}_{+}\right)} \delta \tilde{\phi}_{+}\right] \delta \tilde{\phi}_{+} d x
\end{aligned}
$$

Using $\delta \tilde{\phi}_{+}=\frac{1}{2} \delta \phi\left(=\frac{1}{2} \sum_{i=1}^{\ell} \phi^{(i)}\right)$, and dividing by $\delta \phi^{(k)}$ we get $\left.\frac{\sum_{i} \phi^{(i)}(x)}{\delta \phi^{(k)}(y)}=\delta(x, y)\right)$. Considering $\delta \tilde{\phi}_{+} \rightarrow 0$, the functional derivative becomes 


$$
\begin{gathered}
\frac{\delta E_{\text {intensity }}}{\delta \phi^{(k)}}=\frac{\gamma_{d}}{4}\left[\frac{\Delta \mu^{2} \Delta \sigma^{2} \tilde{\phi}_{+}^{2}+2 \Delta \mu^{2} \sigma_{-}^{2} \tilde{\phi}_{+}}{\left(\sigma_{-}^{2}+\Delta \sigma^{2} \tilde{\phi}_{+}\right)^{2}}\right. \\
\left.+\frac{-2 \Delta \mu \sigma_{-}^{2}\left(I-\mu_{-}\right)-\Delta \sigma^{2}\left(I-\mu_{-}\right)^{2}}{\left(\sigma_{-}^{2}+\Delta \sigma^{2} \tilde{\phi}_{+}\right)^{2}}\right] .
\end{gathered}
$$

To work with stable calculations during the gradient descent method we had to limit the values of the meta phase field $\widetilde{\phi}_{+}$. This can be achieve by using tanh on the individual phase field layers. Let the new meta phase field be $\phi_{+}=\sum_{i=1}^{\ell} \frac{\left(\tanh \left(\phi^{(i)}\right)+1\right)}{2}$. The final form of the functional derivative gets then

$$
\begin{aligned}
\frac{\delta E_{\text {intensity }}}{\delta \phi^{(k)}}= & \frac{1}{4} \operatorname{sech}^{2}\left(\phi^{(k)}\right)\left[\frac{\Delta \mu^{2} \Delta \sigma^{2} \phi_{+}^{2}+2 \Delta \mu^{2} \sigma_{-}^{2} \phi_{+}}{\left(\sigma_{-}^{2}+\Delta \sigma^{2} \phi_{+}\right)^{2}}\right. \\
& \left.+\frac{-2 \Delta \mu \sigma_{-}^{2}\left(I-\mu_{-}\right)-\Delta \sigma^{2}\left(I-\mu_{-}\right)^{2}}{\left(\sigma_{-}^{2}+\Delta \sigma^{2} \phi_{+}\right)^{2}}\right] .
\end{aligned}
$$





\section{Appendix B}

\section{Euler-Lagrange equations for the arbitrary function of the curvature}

Functionals for geometric active contours can be built from invariant (parameterization independent) quantities and the position vector. For planar curves, the first order invariant is the unit tangent vector $\mathbf{t}=\frac{\dot{\mathbf{r}}}{|\dot{\mathbf{r}}|}$ or equivalently the unit normal vector of the curve $\mathbf{n}=\mathbf{k} \times \mathbf{t}$. The second order invariant is the signed curvature $\kappa=\frac{\ddot{\mathbf{r}} \cdot \mathbf{n}}{|\dot{\mathbf{r}}|^{2}}$ or the 'curvature vector' $\kappa \mathbf{n}$. Note that the definition of the curve normal with the direction of the second derivative of the position vector w.r.t. arc length parameter $\left(\frac{d^{2} \mathbf{r}}{d s^{2}}\right), d s=|\dot{\mathbf{r}}| d t$ would lead to an unsigned definition of the curvature: the Frenet frame, however defining the signed curvature using the normal vector of the plane, the Frenet-Serret formulas for planar curve: $\frac{d \mathbf{t}}{d s}=\kappa \mathbf{n}, \frac{d \mathbf{n}}{d s}=-\kappa \mathbf{t}$ still remain valid.

Here we derive the Euler-Lagrange equation for the arbitrary function $f$ of the signed curvature. The Lagrangian of the geometric curvature function is

$$
\begin{gathered}
L(\dot{\mathbf{r}}, \ddot{\mathbf{r}})=f(\kappa)|\dot{\mathbf{r}}| \\
\mathrm{n}_{t} \cdot \mathrm{e}_{t \tau}+\mathrm{n}_{\tau} \cdot \mathrm{e}_{\tau t}=\mathrm{n}_{t} \cdot \frac{\mathrm{r}_{\tau}-\mathrm{r}_{t}}{\left|\mathrm{r}_{\tau}-\mathrm{r}_{t}\right|}-\mathrm{n}_{\tau} \cdot \frac{\mathrm{r}_{\mathrm{t}}-\mathrm{r}_{t}}{\left|\mathrm{r}_{\tau}-\mathrm{r}_{t}\right|}=\frac{\left(\mathrm{n}_{t}-\mathrm{n}_{\mathrm{t}}\right) \cdot\left(\mathrm{r}_{\mathrm{t}}-\mathrm{r}_{t}\right)}{\left|\mathrm{r}_{\tau}-\mathrm{r}_{t}\right|}=\left(\mathrm{n}_{t}-\mathrm{n}_{\tau}\right) \cdot \mathrm{e}_{t \tau}
\end{gathered}
$$

the partial derivatives of the Lagrangian $\frac{\partial L}{\partial \dot{\mathbf{r}}}=|\dot{\mathbf{r}}| \frac{d f}{d \kappa} \frac{\partial \kappa}{\partial \dot{\mathbf{r}}}+f \mathbf{t}, \frac{\partial L}{\partial \ddot{\mathbf{r}}}=|\dot{\mathbf{r}}| \frac{d f}{d \kappa} \frac{\partial \kappa}{\partial \ddot{\mathbf{r}}}$ become

$$
\begin{gathered}
\frac{\partial L}{\partial \dot{\mathbf{r}}}=\left(\frac{\ddot{\mathbf{r}} \times \mathbf{k}}{|\dot{\mathbf{r}}|^{2}}-3 \kappa \mathbf{t}\right) \frac{d f}{d \kappa}+f \mathbf{t} \\
\frac{\partial L}{\partial \ddot{\mathbf{r}}}=\frac{d f}{d \kappa} \frac{\mathbf{n}}{|\dot{\mathbf{r}}|}
\end{gathered}
$$

using the decomposition: $\ddot{\mathbf{r}} \times \mathbf{k}=-(\ddot{\mathbf{r}} \cdot \mathbf{t}) \mathbf{n}+(\ddot{\mathbf{r}} \cdot \mathbf{n}) \mathbf{t}$, the first line of (11) is

$$
\frac{\partial L}{\partial \dot{\mathbf{r}}}=\left(\frac{-(\ddot{\mathbf{r}} \cdot \mathbf{t}) \mathbf{n}+(\ddot{\mathbf{r}} \cdot \mathbf{n}) \mathbf{t}}{|\dot{\mathbf{r}}|^{2}}-3 \kappa \mathbf{t}\right) \frac{d f}{d \kappa}+f \mathbf{t} .
$$


We also need the derivatives of (11) w.r.t. contour parameter $t$ as:

$$
\begin{aligned}
\frac{d t}{d t} \frac{\partial L}{\partial \ddot{\mathbf{r}}} & =\frac{d^{2} f}{d \kappa^{2}} \frac{\partial \kappa}{\partial s} \mathbf{n}+\frac{d f}{d \kappa} \frac{-|\dot{\mathbf{r}}|^{2} \kappa \mathbf{t}-\frac{\dot{\mathbf{r}} \ddot{\mathbf{r}}}{\mid \dot{\mathbf{r}}} \mathbf{n}}{|\dot{\mathbf{r}}|^{2}} \\
& =\frac{d^{2} f}{d \kappa^{2}} \frac{\partial \kappa}{\partial s} \mathbf{n}-\frac{d f}{d \kappa} \kappa \mathbf{t}-\frac{d f}{d \kappa} \frac{\mathbf{t} \cdot \ddot{\mathbf{r}}}{|\dot{\mathbf{r}}|^{2}} \mathbf{n}
\end{aligned}
$$

The left hand side of the Euler-Lagrange equation $\frac{d}{d t}\left(\frac{d}{d t} \frac{\partial L}{\partial \ddot{\mathbf{r}}}-\frac{\partial L}{\partial \dot{\mathbf{r}}}\right)=0$ is:

$$
\begin{aligned}
& \frac{d}{d t}\left(\frac{d^{2} f}{d \kappa^{2}} \frac{\partial \kappa}{\partial s} \mathbf{n}+2 \frac{d f}{d \kappa} \kappa \mathbf{t}-\frac{d f}{d \kappa} \frac{\ddot{\mathbf{r}} \cdot \mathbf{n}}{|\dot{\mathbf{r}}|^{2}} \mathbf{t}-f \mathbf{t}\right) \\
& =|\dot{\mathbf{r}}| \frac{d}{d s}\left[\frac{d^{2} f}{d \kappa^{2}} \frac{d \kappa}{d s} \mathbf{n}+\left(\frac{d f}{d \kappa} \kappa-f\right) \mathbf{t}\right] \\
& =|\dot{\mathbf{r}}|\left[\frac{d}{d s}\left(\frac{d^{2} f}{d \kappa^{2}} \frac{d \kappa}{d s}\right)+\left(\frac{d f}{d \kappa} \kappa-f\right) \kappa\right] \mathbf{n} \\
& +|\dot{\mathbf{r}}|\left[-\left(\frac{d^{2} f}{d \kappa^{2}} \frac{d \kappa}{d s}\right) \kappa+\frac{d}{d s}\left(\frac{d f}{d \kappa} \kappa-f\right)\right] \mathbf{t} .
\end{aligned}
$$

The tangential component (the last line) is zero as usual in the geometric active contour case and the Euler-Lagrange equation of the arbitrary function of the signed curvature becomes:

$$
|\dot{\mathbf{r}}|\left[\frac{d}{d s}\left(\frac{d^{2} f}{d \kappa^{2}} \frac{d \kappa}{d s}\right)+\left(\frac{d f}{d \kappa} \kappa-f\right) \kappa\right] \mathbf{n}=0 .
$$

Choosing $f$ to be the 'Euler elastica' function, the half of the square of the signed curvature: $f(\kappa) \equiv \frac{1}{2} \kappa^{2}$, the associated equation

$$
|\dot{\mathbf{r}}|\left(\frac{d^{2} \kappa}{d s^{2}}+\frac{1}{2} \kappa^{3}\right) \mathbf{n}=0
$$

is used as the smoothness term for the plasma prior.

\section{Euler-Lagrange equation for the second central mo- ment}

The dimension-less second moment of the contour with simple arclength minimizing smoothness term prefers ellipse-like structures and can be defined with the formula $p=$ $\frac{\oint d A \oint d s}{\oint\left|\mathbf{r}-\mathbf{r}_{0}\right|^{2} d s}$, where $\mathbf{r}$ is the position vector of the contour, $\mathbf{r}_{0}=\frac{\oint \mathbf{r} d s}{\oint d s}$ is the center of gravity. Hereinafter we derive the associated Euler-Lagrange equation for the denominator. The result is used in the ellipse shape prior equation. During the derivation of the EulerLagrange equation, the center of gravity is treated as constant. Note that the center of 
gravity itself is given by integral containing the minimizing contour $\mathbf{r}$, thus the subject of the perturbation too. One can however, consider the double minimization problem instead: $\min _{\mathbf{r}, \mathbf{r}_{0}} \oint\left|\mathbf{r}-\mathbf{r}_{0}\right|^{2} d s$, where the minimizer w.r.t. $\mathbf{r}_{0}$ is given by simple extreme value determination $\frac{\partial \oint\left|\mathbf{r}-\mathbf{r}_{0}\right|^{2} d s}{\partial \mathbf{r}_{0}}=0$ and the solution is the center of gravity $\mathbf{r}_{0}=\frac{\oint \mathbf{r} d s}{\oint d s}$. The double minimization problem can then be solved in two steps. First calculating the center of gravity. Second solving the Euler-Lagrange for $\mathbf{r}$, using the predetermined $\mathbf{r}_{0}$. Also note that solving the Euer Lagrange equation iteratively in gradient descent direction requires the center of gravity to be updated in each iteration.

The Lagrangian and the partial derivatives of the geometric second moment are:

$$
\begin{aligned}
L & =\left|\mathbf{r}-\mathbf{r}_{0}\right|^{2}|\dot{\mathbf{r}}| \\
\frac{\partial L}{\partial \mathbf{r}} & =2|\dot{\mathbf{r}}|\left(\mathbf{r}-\mathbf{r}_{0}\right) \\
\frac{\partial L}{\partial \dot{\mathbf{r}}} & =\left|\mathbf{r}-\mathbf{r}_{0}\right|^{2} \mathbf{t},
\end{aligned}
$$

where $\mathbf{t}=\frac{\dot{\mathbf{r}}}{|\dot{\mathbf{r}}|}$ is the unit tangent vector of the contour. Differential operators $\frac{d}{d s}$ and $\frac{d}{d t}$ are related by $\frac{d}{d t}=|\dot{\mathbf{r}}| \frac{d}{d t}$, hence:

$$
\begin{aligned}
\frac{d}{d t} \frac{\partial L}{\partial \dot{\mathbf{r}}} & =|\dot{\mathbf{r}}| \frac{d}{d s}\left(\left|\mathbf{r}-\mathbf{r}_{0}\right|^{2} \mathbf{t}\right) \\
& =|\dot{\mathbf{r}}|\left[2\left(\mathbf{r}-\mathbf{r}_{0}\right) \cdot \mathbf{t t}+\left|\mathbf{r}-\mathbf{r}_{0}\right|^{2} \kappa \mathbf{n}\right]
\end{aligned}
$$

and the Euler-Lagrange equation $\frac{\partial L}{\partial \mathbf{r}}-\frac{d}{d t} \frac{\partial L}{\partial \dot{\mathbf{r}}}=0$ has component only in the normal direction

$$
|\dot{\mathbf{r}}|\left[2\left(\mathbf{r}-\mathbf{r}_{0}\right) \cdot \mathbf{n}-\left|\mathbf{r}-\mathbf{r}_{0}\right|^{2} \kappa\right] \mathbf{n}=0,
$$

or using the notation $\mathbf{r}_{0 t} \doteq \mathbf{r}-\mathbf{r}_{0}$ for the position vector originated from the center of gravity we have

$$
|\dot{\mathbf{r}}|\left[2 \mathbf{r}_{0 t} \cdot \mathbf{n}-\left|\mathbf{r}_{0 t}\right|^{2} \kappa\right] \mathbf{n}=0
$$

to get this result, the decomposition $\mathbf{r}_{0 t}=\mathbf{r}_{0 t} \cdot \mathbf{I}=\mathbf{r}_{0 t} \cdot \mathbf{t t}+\mathbf{r}_{0 t} \cdot \mathbf{n n}$ was used.

\section{Euler-Lagrange equation for geometric local region}

The geometric approximation of a planar curve, parameterized by arc length is:

$$
\mathbf{r}(s+\xi) \approx \mathbf{r}(s)+\xi \mathbf{t}(s)+\frac{\xi^{2}}{2} \kappa \mathbf{n}(s)+\ldots
$$

This approximation can be the basis of a set of local region data terms with local geometric information of the contour and local anisotropy of the image data encoded. 
The simplest - first order - geometric local region functional for a planar curve has to explicitly include one of the local basis vector of the Frenet frame $\mathbf{t}, \mathbf{n}, \mathbf{k}$ (where $\mathbf{k}$ is the unit normal of the plane and $\mathbf{t}$ is the unit tangent vector of the curve). Choosing the unit normal vector of the curve the unit tangent is then given by $\mathbf{t}=\mathbf{n} \times \mathbf{k}$. Here we provide a simple derivation of the Euler-Lagrange equation for the functional:

$$
\mathcal{F}(\mathbf{r}, \dot{\mathbf{r}})=\oint \Phi(\mathbf{r}, \mathbf{n})|\dot{\mathbf{r}}| d t .
$$

The partial derivatives for $L=\Phi(\mathbf{r}, \mathbf{n})|\dot{\mathbf{r}}|$ are:

$$
\begin{aligned}
& \frac{\partial L}{\partial \mathbf{r}}=|\dot{\mathbf{r}}| \Phi_{\mathbf{r}} \\
& \frac{\partial L}{\partial \dot{\mathbf{r}}}=\Phi \mathbf{t}+|\dot{\mathbf{r}}| \Phi_{\mathbf{n}} \cdot\left(\mathbf{k} \times \frac{\mathbf{n n}}{|\dot{\mathbf{r}}|}\right)=\Phi \mathbf{t}-\Phi_{\mathbf{n}} \cdot \mathbf{t} \mathbf{n}
\end{aligned}
$$

where we used: $\mathbf{t}=\frac{\dot{\mathbf{r}}}{|\dot{\mathbf{r}}|} \rightarrow \frac{d \mathbf{t}}{d \dot{\mathbf{r}}}=\frac{1}{|\dot{\mathbf{r}}|}\left(\mathbf{I}-\dot{\mathbf{r}} \frac{\dot{\mathbf{r}}}{|\dot{\mathbf{r}}|^{2}}\right)=\frac{\text { nn }}{|\dot{\mathbf{r}}|}$ (the identity tensor is expressed in the planar Frenet frame as $\mathbf{I}=\mathbf{t t}+\mathbf{n n})$. The term $\frac{d}{d t} \frac{\partial L}{\partial \dot{\mathbf{r}}}=|\dot{\mathbf{r}}| \frac{d}{d s} \frac{\partial L}{\partial \dot{\mathbf{r}}}$ is:

$$
\begin{aligned}
\frac{d}{d t} \frac{\partial L}{\partial \dot{\mathbf{r}}} & =|\dot{\mathbf{r}}|\left[\left(\Phi_{\mathbf{r}} \cdot \mathbf{t}-\kappa \Phi_{\mathbf{n}} \cdot \mathbf{t}\right) \mathbf{t}+\kappa \Phi \mathbf{n}\right] \\
& -|\dot{\mathbf{r}}|\left[\left(\Phi_{\mathbf{n r}} \cdot \mathbf{t}-\kappa \Phi_{\mathbf{n n}} \cdot \mathbf{t}\right) \cdot \mathbf{t}+\kappa \Phi_{\mathbf{n}} \cdot \mathbf{n}\right] \mathbf{n} \\
& +|\dot{\mathbf{r}}| \kappa\left(\Phi_{\mathbf{n}} \cdot \mathbf{t}\right) \mathbf{t}
\end{aligned}
$$

where the derivative formulae of the composite functional are used as $\frac{\partial \Phi}{\partial s}=\Phi_{\mathbf{r}} \cdot \frac{d \mathbf{r}}{d s}+\Phi_{\mathbf{n}} \cdot \frac{d \mathbf{n}}{d s}$ and $\frac{\partial \Phi_{\mathrm{n}}}{\partial s}=\Phi_{\mathrm{nr}} \cdot \frac{d \mathbf{r}}{d s}+\Phi_{\mathrm{nn}} \cdot \frac{d \mathbf{n}}{d s}$. Also the definition of the unit tangent vector $\frac{d \mathbf{r}}{d s}=\mathbf{t}$ and the planar Frenet-Serret formulae $\frac{d \mathbf{t}}{d s}=\kappa \mathbf{n}, \frac{d \mathbf{n}}{d s}=-\kappa \mathbf{t}$ are substituted. In (24) the first line is the derivative of the first term of (23), the second and the third lines are the derivative of the second term of (23) w.r.t. arclength. The last term is canceled by the second term in the first line, hence

$$
\begin{gathered}
\frac{d}{d t} \frac{\partial L}{\partial \dot{\mathbf{r}}}=|\dot{\mathbf{r}}|\left[\Phi_{\mathbf{r}} \cdot \mathbf{t t}-\left(\Phi_{\mathbf{n r}} \cdot \mathbf{t}-\kappa \Phi_{\mathbf{n n}} \cdot \mathbf{t}\right) \cdot \mathbf{t n}\right. \\
\left.+\kappa \Phi_{\mathbf{n}} \cdot \mathbf{n n}-\kappa \Phi \mathbf{n}\right] .
\end{gathered}
$$

The Euler-Lagrange equation $\frac{\partial L}{\partial \mathbf{r}}-\frac{d}{d t} \frac{\partial L}{\partial \dot{\mathbf{r}}}=0$ has the component only in the normal direction such that

$$
\begin{gathered}
|\dot{\mathbf{r}}|\left[\mathbf{t} \cdot\left(\Phi_{\mathrm{nr}}-\kappa \Phi_{\mathbf{n n}}\right) \cdot \mathbf{t}\right. \\
\left.+\kappa\left(\Phi_{\mathbf{n}} \cdot \mathbf{n}-\Phi\right)+\Phi_{\mathbf{r}} \cdot \mathbf{n}\right] \mathbf{n}=0
\end{gathered}
$$

where the decomposition $\Phi_{\mathbf{r}}=\Phi_{\mathbf{r}} \cdot \mathbf{I}=\Phi_{\mathbf{r}} \cdot \mathbf{t t}+\Phi_{\mathbf{r}} \cdot \mathbf{n n}$ is applied for the second line of (23). 


\section{Specialization for image segmentation}

Equation (26) can be specialized for different problems represented by the function $\Phi$. For image segmentation, any regional image statistics, like intensity mean difference or Mahalanobis distance between the regions on the two sides of the contour can be used. The position vector $\mathbf{p}$, as a sum of two vectors: the origin of the Frenet frame $\mathbf{r}$ and the local vector $\xi \mathbf{t}+\eta \mathbf{n}$ is written as

$$
\begin{aligned}
\mathbf{p} & =\mathbf{r}+\xi \mathbf{t}+\eta \mathbf{n} \\
& =\mathbf{r}-\xi(\mathbf{k} \times \mathbf{n})+\eta \mathbf{n} .
\end{aligned}
$$

Now we define two local regions along the contour given by the Cartesian products of the local coordinates: $\mathfrak{R}^{+}: \xi \in[-p, p] \times \eta \in[0, q], \mathfrak{R}^{-}: \xi \in[-p, p] \times \eta \in[-q, 0]$, and the corresponding intensity sum functions $\phi^{+}: \mathfrak{R}^{+} \mapsto[0,2 p q], \phi^{-}: \mathfrak{R}^{-} \mapsto[0,2 p q]$ (here we assumed normalized image intensity function $I$ ). The segmentation problem is then represented by the intensity mean difference function $\Phi=\frac{1}{2 p q}\left(\phi^{+}-\phi^{-}\right)$expressed with local integrals

$$
\Phi(\mathbf{r}, \mathbf{n})=\frac{1}{\|\mathfrak{R}\|}\left(\iint_{\mathfrak{R}^{+}} I(\mathbf{p}) d A-\iint_{\mathfrak{R}^{-}} I(\mathbf{p}) d A\right) .
$$

where $d A=d \xi d \eta,\|\Re\|=2 p q$. Note that the functional (28) has minimum if region $\mathfrak{R}^{+}$has a lower mean intensity than of $\mathfrak{R}^{-}$(for the opposite case the signs of $\phi^{+}$and $\phi^{-}$have to be reversed). Also, the boundaries of the local integrals are independent of $\mathbf{r}$ and $\mathbf{n}$ hence parametric w.r.t. these quantities.

\section{Calculating the derivatives}

The Euler-Lagrange equation (26) requires the calculation of the projection of the gradients $\Phi_{\mathbf{r}}$ and $\Phi_{\mathbf{n}}$ to the unit normal vector and the projection of the second gradients $\left(\Phi_{\mathbf{n r}}, \Phi_{\mathbf{n n}}\right)$ to the tangent direction ${ }^{1}$. We will need the derivatives of $\mathbf{p}$ defined in $(27)$. From the unity property of $\mathbf{n}$ :

$$
\mathbf{n} \cdot \mathbf{n} \equiv 1 \rightarrow \frac{d \mathbf{n}}{d \mathbf{n}}=\mathbf{I}-\mathbf{n n}=\mathbf{t t}
$$

i.e. the directional derivative in any direction $\mathbf{v}: \frac{d \mathbf{n}}{d \mathbf{n}} \cdot \mathbf{v}=\mathbf{t} \mathbf{t} \cdot \mathbf{v}$ has a component only in the tangent direction, i.e. $\frac{d \mathbf{n}}{d \mathbf{n}} \cdot \mathbf{n}=0$, hence the derivatives of the position vector $\mathbf{p}$ are

\footnotetext{
${ }^{1} \Phi_{\mathbf{n}}, \Phi_{\mathbf{n n}}$ are the 'gradients in the normal direction' and in the standard basis their components are the partial derivatives w.r.t. the components of unit normal vector.
} 


$$
\begin{aligned}
& \frac{\partial \mathbf{p}}{\partial \mathbf{r}}=\mathbf{I}=\mathbf{t t}+\mathbf{n n} \\
& \begin{aligned}
\frac{d \mathbf{p}}{d \mathbf{n}} & =-\xi \mathbf{k} \times \mathbf{t t}+\eta \mathbf{t t} \\
& =-\xi \mathbf{n t}+\eta \mathbf{t t} .
\end{aligned}
\end{aligned}
$$

The derivatives in (26) are the normalized differences of the derivatives of the local integrals $\phi^{+}$and $\phi^{-}$. Let $\phi$ stand for either of these integrals. The first order quantities are

$$
\begin{aligned}
\phi_{\mathbf{r}} & =\iint I \nabla d A \\
\phi_{\mathbf{r}} \cdot \mathbf{n} & =\iint I \nabla \cdot \mathbf{n} d A \\
& =\iint I_{\eta} d A
\end{aligned}
$$

and

$$
\begin{aligned}
\phi_{\mathbf{n}} & =\iint I \nabla \cdot(-\xi \mathbf{n t}+\eta \mathbf{t} \mathbf{t}) d A \\
& =\iint(-\xi I \nabla \cdot \mathbf{n}+\eta I \nabla \cdot \mathbf{t}) \mathbf{t} d A \\
\phi_{\mathbf{n}} \cdot \mathbf{n} & =0 .
\end{aligned}
$$

The second order quantities are

$$
\begin{aligned}
\phi_{\mathbf{n r}} & =\iint \mathbf{t}(-\xi \mathbf{n} \cdot I \nabla \nabla+\eta \mathbf{t} \cdot I \nabla \nabla) d A \\
\mathbf{t} \cdot \phi_{\mathbf{n r}} \cdot \mathbf{t} & =\iint(-\xi \mathbf{n} \cdot I \nabla \nabla \cdot \mathbf{t}+\eta \mathbf{t} \cdot I \nabla \nabla \cdot \mathbf{t}) d A \\
& =\iint\left(-\xi I_{\eta \xi}+\eta I_{\xi \xi}\right) d A
\end{aligned}
$$

and (using $\left.\frac{d \mathbf{t}}{d \mathbf{n}}=\frac{d(-\mathbf{k} \times \mathbf{n})}{d \mathbf{n}}=-\mathbf{n t}\right)$ 


$$
\begin{aligned}
\phi_{\mathbf{n n}} & =\iint \mathbf{t}(-\xi \mathbf{n}+\eta \mathbf{t}) \cdot I \nabla \nabla \cdot(-\xi \mathbf{n t}+\eta \mathbf{t} \mathbf{t}) d A \\
& -\iint(-\xi I \nabla \cdot \mathbf{n}+\eta I \nabla \cdot \mathbf{t}) \mathbf{n t} d A \\
& +\iint \mathbf{t}(-\xi I \nabla \cdot \mathbf{t} \mathbf{t}-\eta I \nabla \cdot \mathbf{n t}) d A \\
\mathbf{t} \cdot \phi_{\mathbf{n n}} \cdot \mathbf{t} & =\iint(-\xi \mathbf{n}+\eta \mathbf{t}) \cdot I \nabla \nabla \cdot(-\xi \mathbf{n}+\eta \mathbf{t}) d A \\
& +\iint(-\xi I \nabla \cdot \mathbf{t}-\eta I \nabla \cdot \mathbf{n}) d A \\
& =\iint \xi^{2} I_{\eta \eta}-2 \xi \eta I_{\xi \eta}+\eta^{2} I_{\xi \xi}-\left(\xi I_{\xi}+\eta I_{\eta}\right) d A
\end{aligned}
$$

${ }^{2}$ In the last lines of the equations (31-34), the quantities of (26) are expressed with the local region coordinates $\xi$ and $\eta$, which allow simplified calculations, for example (31) can be calculated as the difference of two line integrals along the "upper" and "lower" boundaries of the local regions (for products, like $\xi I_{\xi}$ or $\eta I_{\eta}$, integration by parts can be applied).

It is obvious from the equations (31-34) that the anisotropy of the image intensity distribution inside the local region is taken into consideration in this model (the multiplication with the local coordinates responsible for this effect). One can observe the following local evolution: a contour point and its neighbourhood move with different speed causing the local coordinate system spins until aligned with the object boundary. This inherent anisotropic behaviour does not occur in the case of local region models (see Fig. 4.4). Note that using second-order curve approximation (21) a local set of the contour points would move with different speed until the curvature of the curve segment they develop coincide with the curvature of the object boundary they approach.

If the image is not plagued with significant amount of noise, the simpler "pointwise version' of the local region equation can be used instead. Hereinafter we discuss the special case.

\section{The pointwise specialization of the local region equation}

Shrinking the local region (28) into one point $\mathbf{r}$ is void of sense, one can rather constitute the limit of difference of the infinitesimal regions such that

$$
\dot{\Phi} \doteq \lim _{\epsilon \rightarrow 0} \frac{1}{\epsilon}\left[\lim _{p, q \rightarrow 0} \frac{1}{2 p q}\left(\phi^{\epsilon}-\phi^{0}\right)\right]
$$

where

\footnotetext{
${ }^{2}$ Note that $I \nabla, I \nabla \nabla$ are dependent on the local coordinates, whereas $\mathbf{n}, \mathbf{t}$ are given at the origin of the local region (thus could be taken out from behind the local integrals).
} 


$$
\begin{aligned}
\phi^{\epsilon} & =\int_{\epsilon}^{q+\epsilon} \int_{-p}^{p} I(\mathbf{p}) d \xi d \eta \\
\phi^{0} & =\int_{-q}^{0} \int_{-p}^{p} I(\mathbf{p}) d \xi d \eta
\end{aligned}
$$

then

$$
\dot{\Phi}=\lim _{\epsilon \rightarrow 0} \frac{I(\mathbf{r}+\epsilon \mathbf{n})-I(\mathbf{r})}{\epsilon},
$$

which is the directional derivative of the image intensity function in the normal direction of the contour: $\dot{\Phi}(\mathbf{r}, \mathbf{n})=I_{\eta}(\mathbf{r})=\mathbf{n} \cdot I \nabla$. The further pointwise constituents of the Euler-Lagrange equation (26) (applying $\xi=0, \eta=\epsilon$ for $\phi^{\epsilon}$ and $\xi=0, \eta=0$ for $\phi^{0}$ ) are:

$$
\begin{aligned}
\dot{\Phi}_{\mathbf{r}} \cdot \mathbf{n} & =\lim _{\epsilon \rightarrow 0} \frac{I_{\eta}(\mathbf{r}+\epsilon \mathbf{n})-I_{\eta}(\mathbf{r})}{\epsilon}=I_{\eta \eta}(\mathbf{r}) \\
\mathbf{t} \cdot \dot{\Phi}_{\mathbf{n r}} \cdot \mathbf{t} & =\lim _{\epsilon \rightarrow 0} \frac{\epsilon I_{\xi \xi}(\mathbf{r}+\epsilon \mathbf{n})}{\epsilon}=I_{\xi \xi}(\mathbf{r}) \\
\mathbf{t} \cdot \dot{\Phi}_{\mathbf{n n}} \cdot \mathbf{t} & =\lim _{\epsilon \rightarrow 0} \frac{\epsilon^{2} I_{\xi \xi}-\epsilon I_{\eta}(\mathbf{r}+\epsilon \mathbf{n})}{\epsilon}=-I_{\eta}(\mathbf{r}),
\end{aligned}
$$

hence the Euler-Lagrange equation associated with the geometric functional $\oint \mathbf{n} \cdot I \nabla d s$ is $|\dot{\mathbf{r}}|\left(I_{\xi \xi}+I_{\eta \eta}\right) \mathbf{n}=\mathbf{0}$ or

$$
|\dot{\mathbf{r}}| \triangle I \mathbf{n}=0
$$

where $\triangle I$ is the Laplace operator that can be calculated either in the standard basis $\mathbf{i}$, $\mathbf{j}$ as $\triangle I=I_{x x}+I_{y y}$ or in the local basis $\mathbf{t}, \mathbf{n}$ as $\triangle I=I_{\xi \xi}+I_{\eta \eta}$.

Note that in some cases, the approximation of the complete equation (26) containing only the first order derivatives

$$
|\dot{\mathbf{r}}|\left[\kappa\left(\Phi_{\mathbf{n}} \cdot \mathbf{n}-\Phi\right)+\Phi_{\mathbf{r}} \cdot \mathbf{n}\right] \mathbf{n}
$$

provides an acceptable solution. This is however, not the case if the local region data metric is chosen to be the mean intensity difference. In this case $\Phi_{\mathbf{n}} \cdot \mathbf{n}=0$ and the pointwise specialization (behaving similarly to the local region)

$$
|\dot{\mathbf{r}}|\left(-\kappa I_{\eta}+I_{\eta \eta}\right) \mathbf{n}=0
$$

is the solution of the functional $\mathcal{F}(\mathbf{r}, \dot{\mathbf{r}})=\oint \Phi(\mathbf{r}) d s$ which does not have the normal vector explicitely, thus cannot display anisotropic behaviour. Moreover, the simplified 
equation has a curvature dependent term causing smoothing effect which is not desirable in our case $^{3}$. This term is eliminated by the second order term $-\kappa \mathbf{t} \cdot \Phi_{\mathbf{n n}} \cdot \mathbf{t}$ in the complete equation.

${ }^{3}$ The influence of the curvature based smoothness term is considered to be too high, comparable with the shape term. To reduce this interference is the reason, why the less powerful Euler elastica based smoothness term is selected instead. 



\section{Appendix C}

\section{Functional derivative of splitting functional}

$$
E_{C A}=-\iint_{\mathbf{r}_{F S} \times \mathbf{r}_{F S}^{\prime}} f_{c}(\kappa(s)) f_{c}\left(\kappa\left(s^{\prime}\right)\right) g_{a}\left(a\left(s, s^{\prime}\right)\right) l\left(d\left(s, s^{\prime}\right)\right) d s d s^{\prime}
$$

The second-order functional Eq. (42) represents the total energy of the contour. The integral is evaluated only on the feasible subset of contour points that satisfy the alignment and curvature conditions.

$$
\begin{aligned}
& \mathcal{F}=\iint f\left(\kappa_{t}+\kappa_{\tau}\right) g\left(\mathbf{n}_{t} \cdot \mathbf{e}_{t \tau}+\mathbf{n}_{\tau} \cdot \mathbf{e}_{\tau t}\right) l\left(d_{t \tau}\right)\left|\dot{\mathbf{r}}_{t}\right|\left|\dot{\mathbf{r}}_{\tau}\right| d \tau d t, \text { where } \\
& \mathbf{n}_{t} \cdot \mathbf{e}_{t \tau}+\mathbf{n}_{\tau} \cdot \mathbf{e}_{\tau t}=\mathbf{n}_{t} \cdot \frac{\mathbf{r}_{\tau}-\mathbf{r}_{t}}{\left|\mathbf{r}_{\tau}-\mathbf{r}_{t}\right|}-\mathbf{n}_{\tau} \cdot \frac{\mathbf{r}_{\mathbf{t}}-\mathbf{r}_{t}}{\left|\mathbf{r}_{\tau}-\mathbf{r}_{t}\right|} \\
&=\frac{\left(\mathbf{n}_{t}-\mathbf{n}_{t}\right) \cdot\left(\mathbf{r}_{t}-\mathbf{r}_{t}\right)}{\left|\mathbf{r}_{\tau}-\mathbf{r}_{t}\right|} \\
&=\left(\mathbf{n}_{t}-\mathbf{n}_{\tau}\right) \cdot \mathbf{e}_{t \tau}
\end{aligned}
$$

The value of this functional is decreased by better alignments $g\left(\mathrm{n}_{t} \cdot \mathrm{e}_{t \tau}+\mathrm{n}_{\mathrm{t}} \cdot \mathrm{e}_{\tau t}\right)$, sharper 'cutting arm' $f\left(\mathrm{k}_{t}+\mathrm{k}_{\mathrm{t}}\right)$ and shorter distances $d_{\tau t}$ between the endpoints of the 'cutting arms'. Finally, Eq. (43) is minimized by a set of contours having zero effective distances (zero value of Eq. (43) is possible iff $d_{\tau t}=0$ ), i.e. the boundaries of separated objects with no pairs of aligned, sharp, concave details.

\section{Euler-Lagrange equations}

The variation of the functional $\mathcal{F}$ is:

$$
\begin{aligned}
& f\left(\mathbf{k} \cdot \frac{(\dot{\mathbf{r}}+\epsilon \dot{\mathbf{h}}) \times(\ddot{\mathbf{r}}+\epsilon \ddot{\mathbf{h}})}{|\dot{\mathbf{r}}+\epsilon \dot{\mathbf{h}}|^{3}}+\mathbf{k} \cdot \frac{(\dot{\mathbf{r}}+\epsilon \dot{\mathbf{h}}) \times(\ddot{\mathbf{r}}+\epsilon \ddot{\mathbf{h}})}{|\dot{\mathbf{r}}+\epsilon \dot{\mathbf{h}}|^{3}}\right) \\
& \iint g\left(\mathbf{k} \cdot\left[\left(\frac{\dot{\mathbf{r}}+\epsilon \dot{\mathbf{h}}_{t}}{\left|\dot{\mathbf{r}}+\epsilon \dot{\mathbf{h}}_{t}\right|}-\frac{\dot{\mathbf{r}}+\epsilon \dot{\mathbf{h}}_{\mathrm{t}}}{\left|\dot{\mathbf{r}}+\epsilon \dot{\mathbf{h}}_{\tau}\right|}\right) \times \frac{\mathbf{r}+\epsilon \mathbf{h}_{\mathrm{t}}-\mathbf{r}+\epsilon \mathbf{h}_{t}}{\left|\mathbf{r}+\epsilon \mathbf{h}_{\tau}-\mathbf{r}+\epsilon \mathbf{h}_{t}\right|}\right]\right) \\
& l\left(\left|\mathbf{r}+\epsilon \mathbf{h}_{\mathrm{t}}-\mathbf{r}-\epsilon \mathbf{h}_{t}\right|\right)\left|\dot{\mathbf{r}}+\epsilon \dot{\mathbf{h}}_{t}\right|\left|\dot{\mathbf{r}}+\epsilon \dot{\mathbf{h}}_{\mathrm{t}}\right| d \tau d t
\end{aligned}
$$


Partial calculations for alignment

$$
\begin{aligned}
& \left.\frac{\partial}{\partial \varepsilon}\right|_{\varepsilon=0} \mathbf{k} \cdot\left[\left(\frac{\dot{\mathbf{r}}+\varepsilon \dot{\mathbf{h}}_{t}}{\left|\dot{\mathbf{r}}+\varepsilon \dot{\mathbf{h}}_{t}\right|}-\frac{\dot{\mathbf{r}}+\varepsilon \dot{\mathbf{h}}_{\tau}}{\left|\dot{\mathbf{r}}+\varepsilon \dot{\mathbf{h}}_{\tau}\right|}\right) \times \frac{\mathbf{r}+\varepsilon \mathbf{h}_{\tau}-\mathbf{r}+\varepsilon \mathbf{h}_{t}}{\left|\mathbf{r}+\varepsilon \mathbf{h}_{\tau}-\mathbf{r}+\varepsilon \mathbf{h}_{t}\right|}\right] \\
& =\mathbf{k} \cdot\left[\left(\frac{|\dot{\mathbf{r}}| \dot{\mathbf{h}}-\dot{\mathbf{r}} \frac{\dot{\mathbf{r}} \cdot \dot{\mathbf{r}}}{|\dot{\mathbf{r}}|}}{|\dot{\mathbf{r}}|^{2}} t-\frac{|\dot{\mathbf{r}}| \dot{\mathbf{h}}-\dot{\mathbf{r}} \frac{\dot{\mathbf{r}} \cdot \dot{\mathbf{h}}}{|\dot{\mathbf{r}}|}}{|\dot{\mathbf{r}}|^{2}}\right) \times \mathbf{e}_{t \tau}\right. \\
& \left.+\left(\mathrm{e}_{t}-\mathrm{e}_{\tau}\right) \times \frac{\left(\mathbf{h}_{\tau}-\mathbf{h}_{t}\right)\left|\mathbf{r}_{\tau}-\mathbf{r}_{t}\right|-\left(\mathbf{r}_{\tau}-\mathbf{r}_{t}\right) \frac{\left(\mathbf{r}_{\tau}-\mathbf{r}_{t}\right)\left(\mathbf{h}_{\tau}-\mathbf{h}_{t}\right)}{\left|\mathbf{r}_{\tau}-\mathbf{r}_{t}\right|}}{\left|\mathbf{r}_{\tau}-\mathbf{r}_{t}\right|^{2}}\right] \\
& =\mathbf{k} \cdot\left[\left(\frac{\mathbf{n}_{t} \mathbf{n}_{t} \cdot \dot{\mathbf{h}}_{t}}{\left|\dot{\mathbf{r}}_{t}\right|}-\frac{\mathbf{n}_{\tau} \mathbf{n}_{\tau} \cdot \dot{\mathbf{h}}_{\tau}}{\left|\dot{\mathbf{r}}_{\tau}\right|}\right) \times \mathbf{e}_{t \tau}+\left(\mathbf{e}_{t}-\mathbf{e}_{\tau}\right) \times \frac{\left(\mathbf{h}_{\tau}-\mathbf{h}_{t}\right)-\mathrm{e}_{t \tau} \mathbf{e}_{t \tau} \cdot\left(\mathbf{h}_{\tau}-\mathbf{h}_{t}\right)}{\left|\mathbf{r}_{\tau}-\mathbf{r}_{t}\right|}\right] \\
& =\mathbf{e}_{t \tau} \cdot\left[\mathbf{k} \times\left(\frac{\mathbf{n}_{t} \mathbf{n}_{t} \cdot \dot{\mathbf{h}}_{t}}{\left|\dot{\mathbf{r}}_{t}\right|}-\frac{\mathbf{n}_{\tau} \mathbf{n}_{\tau} \cdot \dot{\mathbf{h}}_{\tau}}{\left|\dot{\mathbf{r}}_{\tau}\right|}\right)\right] \\
& +\frac{\left(\mathbf{h}_{\tau}-\mathbf{h}_{t}\right)-\mathbf{e}_{t \tau} \mathbf{e}_{t \tau} \cdot\left(\mathbf{h}_{\tau}-\mathbf{h}_{t}\right)}{\left|\mathbf{r}_{\tau}-\mathbf{r}_{t}\right|} \cdot\left[\mathbf{k} \times\left(\mathbf{e}_{t}-\mathbf{e}_{\tau}\right)\right] \\
& =\dot{\mathbf{h}}_{\tau} \cdot \mathbf{n}_{\tau} \frac{\mathrm{e}_{t \tau} \cdot \mathbf{e}_{\tau}}{\left|\dot{\mathbf{r}}_{\tau}\right|}-\dot{\mathbf{h}}_{t} \cdot \mathbf{n}_{t} \frac{\mathrm{e}_{t \tau} \cdot \mathbf{e}_{t}}{\left|\dot{\mathbf{r}}_{t}\right|} \\
& +\mathbf{h}_{\tau} \cdot \frac{\left(\mathbf{n}_{t}-\mathbf{n}_{\tau}\right)-\mathrm{e}_{t \tau} \mathbf{e}_{t \tau} \cdot\left(\mathbf{n}_{t}-\mathbf{n}_{\tau}\right)}{d_{t \tau}}-\mathbf{h}_{t} \cdot \frac{\left(\mathbf{n}_{t}-\mathbf{n}_{\tau}\right)-\mathrm{e}_{t \tau} \mathbf{e}_{t \tau} \cdot\left(\mathbf{n}_{t}-\mathbf{n}_{\tau}\right)}{d_{t \tau}}
\end{aligned}
$$

\section{Partial calculations for distance}

$$
\begin{aligned}
& \left.\frac{\partial}{\partial \varepsilon}\right|_{\varepsilon=0} l\left(\left|\mathbf{r}+\epsilon \mathbf{h}_{\tau}-\mathbf{r}-\epsilon \mathbf{h}_{t}\right|\right)\left|\dot{\mathbf{r}}+\dot{\mathbf{h}}_{\tau} \| \dot{\mathbf{r}}+\dot{\mathbf{h}}_{t}\right| \\
& =l^{\prime}\left(d_{t \tau}\right) \frac{\left(\mathbf{r}_{\tau}-\mathbf{r}_{t}\right) \cdot\left(\mathbf{h}_{\tau}-\mathbf{h}_{t}\right)}{\left|\mathbf{r}_{\tau}-\mathbf{r}_{t}\right|}\left|\dot{\mathbf{r}}_{t}\right|\left|\dot{\mathbf{r}}_{\tau}\right|+l\left(d_{t \tau}\right)\left|\dot{\mathbf{r}}_{\tau}\right| \frac{\dot{\mathbf{r}}_{t} \cdot \dot{\mathbf{h}}_{t}}{\left|\dot{\mathbf{r}}_{t}\right|}+l\left(d_{t \tau}\right)\left|\dot{\mathbf{r}}_{t}\right| \frac{\dot{\mathbf{r}}_{\tau} \cdot \dot{\mathbf{h}}_{\tau}}{\left|\dot{\mathbf{r}}_{\tau}\right|} \\
& =\mathbf{h}_{\tau} \cdot \mathbf{e}_{t \tau} l^{\prime}\left(d_{t \tau}\right)\left|\dot{\mathbf{r}}_{t}\right|\left|\dot{\mathbf{r}}_{\tau}\right|-\mathbf{h}_{t} \cdot \mathbf{e}_{t \tau} l^{\prime}\left(d_{t \tau}\right)\left|\dot{\mathbf{r}}_{t}\right|\left|\dot{\mathbf{r}}_{\tau}\right|+\dot{\mathbf{h}}_{t} \cdot \mathrm{e}_{t} l\left(d_{t \tau}\right)\left|\dot{\mathbf{r}}_{\tau}\right|+\dot{\mathbf{h}}_{\tau} \cdot \mathbf{e}_{\tau} l\left(d_{t \tau}\right)\left|\dot{\mathbf{r}}_{t}\right|
\end{aligned}
$$




\section{Partial calculations for curvature}

$$
\begin{aligned}
& \left.\frac{\partial}{\partial \varepsilon}\right|_{\varepsilon=0} \mathbf{k} \cdot \frac{(\dot{\mathbf{r}}+\varepsilon \dot{\mathbf{h}}) \times(\ddot{\mathbf{r}}+\varepsilon \ddot{\mathbf{h}})}{|\dot{\mathbf{r}}+\varepsilon \dot{\mathbf{h}}|^{3}}=\mathbf{k} \cdot \frac{\dot{\mathbf{h}} \times \ddot{\mathbf{r}}|\dot{\mathbf{r}}|^{3}+\dot{\mathbf{r}} \times \ddot{\mathbf{h}}|\dot{\mathbf{r}}|^{3}-3|\dot{\mathbf{r}}|^{2} \dot{\mathbf{r}} \times \ddot{\mathbf{r}} \frac{\dot{\mathbf{r}} \cdot \dot{\mathbf{h}}}{|\dot{\mathbf{r}}|}}{|\dot{\mathbf{r}}|^{6}} \\
& =\mathbf{k} \cdot \frac{\dot{\mathbf{h}} \times \ddot{\mathbf{r}}-\ddot{\mathbf{h}} \times \dot{\mathbf{r}}-3 \mathbf{e} \times \ddot{\mathbf{r}}(\mathbf{e} \cdot \dot{\mathbf{h}})}{|\dot{\mathbf{r}}|^{3}}=\frac{1}{|\dot{\mathbf{r}}|^{3}}[\dot{\mathbf{h}} \cdot(\ddot{\mathbf{r}} \times \mathbf{k})-\ddot{\mathbf{h}} \cdot(\ddot{\mathbf{r}} \times \mathbf{k})-3 \mathbf{e} \cdot(\ddot{\mathbf{r}} \times \mathbf{k})(\mathbf{e} \cdot \dot{\mathbf{h}})] \\
& =\ddot{\mathbf{h}} \cdot \frac{\mathbf{n}}{|\dot{\mathbf{r}}|^{2}}-\dot{\mathbf{h}} \cdot \frac{(\ddot{\mathbf{r}} \cdot \mathrm{e}) \mathbf{n}+2(\ddot{\mathbf{r}} \cdot \mathbf{n}) \mathrm{e}}{|\dot{\mathbf{r}}|^{3}}=\ddot{\mathbf{h}} \cdot \frac{\mathbf{n}}{|\dot{\mathbf{r}}|^{2}}-\dot{\mathbf{h}} \cdot \frac{1}{|\dot{\mathbf{r}}|}\left(2 \kappa \mathbf{e}+\frac{\ddot{\mathbf{r}} \cdot \mathrm{e}}{|\dot{\mathbf{r}}|^{2}} \mathbf{n}\right)
\end{aligned}
$$

\section{Functional derivative of the splitting function}

The functional derivative of the overall higher-order functional is:

$$
\begin{aligned}
& \left|\dot{\mathbf{r}}_{t}\right| \mathbf{n}_{t} \int f^{\prime \prime \prime}\left(\kappa_{t}\right)\left(\frac{d \kappa_{t}}{d s}\right)^{2} g\left(\mathbf{e}_{t \tau} \cdot \mathbf{n}_{t}+\mathbf{e}_{\tau t} \cdot \mathbf{n}_{\tau}\right) l\left(d_{t \tau}\right) f\left(\kappa_{\tau}\right)\left|\dot{\mathbf{r}}_{\tau}\right| d \tau \\
+ & \left|\dot{\mathbf{r}}_{t}\right| \mathbf{n}_{t} \int f^{\prime \prime}\left(\kappa_{t}\right) \frac{d^{2} \kappa_{t}}{d s^{2}} g\left(\mathbf{e}_{t \tau} \cdot \mathbf{n}_{t}+\mathbf{e}_{\tau t} \cdot \mathbf{n}_{\tau}\right) l\left(d_{t \tau}\right) f\left(\kappa_{\tau}\right)\left|\dot{\mathbf{r}}_{\tau}\right| d \tau \\
+ & 2\left|\dot{\mathbf{r}}_{t}\right| \mathbf{n}_{t} \int \frac{d \kappa_{t}}{d s} f^{\prime \prime}\left(\kappa_{t}\right) g^{\prime}\left(\mathbf{e}_{t \tau} \cdot \mathbf{n}_{t}+\mathbf{e}_{\tau t} \cdot \mathbf{n}_{\tau}\right)\left[\mathbf{e}_{t} \cdot \mathbf{n}_{t \tau} \mathbf{n}_{t \tau} \cdot \mathbf{n}_{\tau}+\mathbf{e}_{t} \cdot \mathbf{e}_{t \tau} \mathbf{e}_{t \tau} \cdot \mathbf{n}_{t}\right. \\
& \left.-\kappa_{t} d_{t \tau} \mathbf{e}_{t} \cdot \mathbf{e}_{t \tau}\right] \frac{l\left(d_{t \tau}\right)}{d_{t \tau}} f\left(\kappa_{\tau}\right)\left|\dot{\mathbf{r}}_{\tau}\right| d \tau \\
- & 2\left|\dot{\mathbf{r}}_{t}\right| \mathbf{n}_{t} \int \frac{d \kappa_{t}}{d s} f^{\prime \prime}\left(\kappa_{t}\right) g\left(\mathbf{e}_{t \tau} \cdot \mathbf{n}_{t}+\mathbf{e}_{\tau t} \cdot \mathbf{n}_{\tau}\right) l^{\prime}\left(d_{t \tau}\right) \mathbf{e}_{t} \cdot \mathbf{e}_{t \tau} f\left(\kappa_{\tau}\right)\left|\dot{\mathbf{r}}_{\tau}\right| \\
+ & \left|\dot{\mathbf{r}}_{t}\right| \mathbf{n}_{t} \int f^{\prime}\left(\kappa_{t}\right) g^{\prime \prime}\left(\mathbf{e}_{t \tau} \cdot \mathbf{n}_{t}+\mathbf{e}_{\tau t} \cdot \mathbf{n}_{\tau}\right)\left[\left(\mathbf{n}_{t}-\mathbf{n}_{\tau}\right) \cdot \mathbf{e}_{t \tau} \mathbf{e}_{t \tau} \cdot \mathbf{e}_{t}+\mathbf{e}_{t} \cdot \mathbf{n}_{\tau}\right. \\
- & \left.\kappa_{t} d_{t \tau} \mathbf{e}_{t} \cdot \mathbf{e}_{t \tau}\right]^{2} \frac{l\left(d_{t \tau}\right)}{d_{t \tau}} f\left(\kappa_{\tau}\right)\left|\dot{\mathbf{r}}_{\tau}\right| d \tau \\
+ & \left|\dot{\mathbf{r}}_{t}\right| \mathbf{n}_{t} \int f^{\prime}\left(\kappa_{t}\right) g^{\prime}\left(\mathbf{e}_{t \tau} \cdot \mathbf{n}_{t}+\mathbf{e}_{\tau t} \cdot \mathbf{n}_{\tau}\right) \kappa_{t}\left[\mathbf{n}_{t} \cdot \mathbf{e}_{t \tau} \mathbf{e}_{t \tau} \cdot \mathbf{n}_{t}+\mathbf{n}_{t} \cdot \mathbf{n}_{t \tau} \mathbf{n}_{t \tau} \cdot \mathbf{n}_{t}\right] \frac{l\left(d_{t \tau}\right)}{d t \tau} f\left(\kappa_{\tau}\right)\left|\dot{\mathbf{r}}_{\tau}\right| d \tau \\
- & \left|\dot{\mathbf{r}}_{t}\right| \mathbf{n}_{t} \int f^{\prime}\left(\kappa_{t}\right) g^{\prime}\left(\mathbf{e}_{t \tau} \cdot \mathbf{n}_{t}+\mathbf{e}_{\tau t} \cdot \mathbf{n}_{\tau}\right)\left[\kappa_{t}^{2} \mathbf{n}_{t} \cdot \mathbf{e}_{t \tau}-\frac{\kappa_{t}}{d_{t \tau}}\right. \\
+ & \frac{\left.\left(\mathbf{n}_{t}-\mathbf{n}_{\tau}\right) \cdot \mathbf{e}_{t \tau}\left(\mathbf{e}_{t \tau} \cdot \mathbf{n}_{t}\right)^{2}\right] l\left(d_{t \tau}\right) f\left(\kappa_{\tau}\right)\left|\dot{\mathbf{r}}_{\tau}\right| d \tau}{d_{t \tau}^{2}} \\
+ & \left|\dot{\mathbf{r}}_{t}\right| \mathbf{n}_{t} \int f^{\prime}\left(\kappa_{t}\right) g^{\prime}\left(\mathbf{e}_{t \tau} \cdot \mathbf{n}_{t}+\mathbf{e}_{\tau t} \cdot \mathbf{n}_{\tau}\right)\left[\frac{l\left(d_{t \tau}\right)}{d_{t \tau}}-l^{\prime}\left(d_{t \tau}\right)\right] \\
& {\left[\left(\mathbf{n}_{t} \cdot \mathbf{n}_{t \tau} \mathbf{n}_{t \tau} \cdot \mathbf{e}_{t}+\mathbf{n}_{t} \cdot \mathbf{e}_{t \tau} \mathbf{e}_{t \tau} \cdot \mathbf{e}_{t}\right) \mathbf{e}_{t} \cdot \mathbf{e}_{t \tau} \kappa_{\tau}\left(\mathbf{e}_{t} \cdot \mathbf{e}_{t \tau}\right)^{2}\right] f\left(\kappa_{\tau}\right)\left|\dot{\mathbf{r}}_{\tau}\right| d \tau }
\end{aligned}
$$


$+\left|\dot{\mathbf{r}}_{t}\right| \mathbf{n}_{t} \int f^{\prime}\left(\kappa_{t}\right) g\left(\mathbf{e}_{t \tau} \cdot \mathbf{n}_{t}+\mathbf{e}_{\tau t} \cdot \mathbf{n}_{\tau}\right)$ $\left[\kappa_{t}^{2} l\left(d_{t \tau}\right)-\kappa_{t} l^{\prime}\left(d_{t \tau}\right) \mathbf{n}_{t} \cdot \mathbf{e}_{t \tau}+\frac{l^{\prime}\left(d_{t \tau}\right)}{d_{t \tau}}\left(\mathbf{n}_{t} \cdot \mathbf{e}_{t \tau}\right)^{2}+l^{\prime \prime}\left(d_{t \tau}\right)\left(\mathbf{e}_{t} \cdot \mathbf{e}_{t \tau}\right)^{2}\right] f\left(\kappa_{\tau}\right)\left|\dot{\mathbf{r}}_{\tau}\right| d \tau$

$-\left|\dot{\mathbf{r}}_{t}\right| \mathbf{n}_{t} \int f\left(\kappa_{t}\right) g^{\prime \prime}\left(\mathbf{e}_{t \tau} \cdot \mathbf{n}_{t}+\mathbf{e}_{\tau t} \cdot \mathbf{n}_{\tau}\right)\left[\left(\mathbf{n}_{t}-\mathbf{n}_{\tau}\right) \cdot \mathbf{n}_{t \tau} \mathbf{n}_{t \tau} \cdot \mathbf{e}_{t}\right.$

$\left.+\kappa_{t} d_{t \tau} \mathbf{e}_{t} \cdot \mathbf{e}_{t \tau}\right] \frac{l\left(d_{t \tau}\right)}{d_{t \tau}} \mathbf{e}_{t} \cdot \mathbf{e}_{t \tau} f\left(\kappa_{\tau}\right)\left|\dot{\mathbf{r}}_{\tau}\right| d \tau$

$-\left|\dot{\mathbf{r}}_{t}\right| \mathbf{n}_{t} \int f\left(\kappa_{t}\right) g^{\prime}\left(\mathbf{e}_{t \tau} \cdot \mathbf{n}_{t}+\mathbf{e}_{\tau t} \cdot \mathbf{n}_{\tau}\right)\left[\left(\mathbf{n}_{t}-\mathbf{n}_{\tau}\right) \cdot \mathbf{n}_{t \tau} \mathbf{n}_{i \tau} \cdot \mathbf{n}_{t}\right.$

$\left.+\kappa_{t} d_{t \tau} \mathbf{n}_{t} \cdot \mathbf{e}_{t \tau}+1\right] \frac{l\left(d_{t \tau}\right)}{d_{t \tau}} f\left(\kappa_{\tau}\right)\left|\dot{\mathbf{r}}_{\tau}\right| d \tau$

$-\left|\dot{\mathbf{r}}_{t}\right| \mathbf{n}_{t} \int f\left(\kappa_{t}\right) g\left(\mathbf{e}_{t \tau} \cdot \mathbf{n}_{t}+\mathbf{e}_{\tau t} \cdot \mathbf{n}_{\tau}\right)\left[l\left(d_{t \tau}\right) \kappa_{t}+l^{\prime}\left(d_{t \tau}\right) \mathbf{n}_{t} \cdot \mathbf{e}_{t \tau}\right]\left|\dot{\mathbf{r}}_{\tau}\right| d \tau$ 


\section{Bibliography}

[1] J. C. Caicedo, S. Cooper, F. Heigwer, S. Warchal, P. Qiu, C. Molnar et al., "Dataanalysis strategies for image-based cell profiling," Nature methods, vol. 14, no. 9, p. $849,2017$.

[2] E. Meijering, "Cell segmentation: 50 years down the road," IEEE Signal Processing Magazine, vol. 29, no. 5, pp. 140-145, 2012.

[3] E. Meijering, A. E. Carpenter, H. Peng, F. A. Hamprecht, and J.-C. Olivo-Marin, "Imagining the future of bioimage analysis," Nature biotechnology, vol. 34, no. 12, p. $1250,2016$.

[4] E. Bengtsson, C. Wahlby, and J. Lindblad, "Robust cell image segmentation methods," Pattern Recognition and Image Analysis C, vol. 14, no. 2, pp. 157-167, 2004.

[5] R. C. Gonzalez and R. E. Woods, Digital Image Processing (3rd Edition). Upper Saddle River, NJ, USA: Prentice-Hall, Inc., 2006.

[6] M. Sonka, V. Hlavac, and R. Boyle, Image processing, analysis, and machine vision. Stamford, CT, USA: Cengage Learning, 2014.

[7] W. K. Pratt, Digital Image Processing (2nd ed.). New York, NY, USA: John Wiley \& Sons, Inc., 1991.

[8] S. Geman and D. Geman, "Stochastic relaxation, Gibbs distributions and the Bayesian restoration of images," IEEE Transactions on Pattern Analysis and Machine Intelligence, vol. 6, pp. 721-741, 1984.

[9] Z. Kato, M. Berthod, and J. Zerubia, "A hierarchical Markov random field model and multi-temperature annealing for parallel image classification," Computer Vision, Graphics and Image Processing: Graphical Models and Image Processing, vol. 58 , no. 1 , pp. 18-37, 1996.

[10] T. Szirányi and J. Zerubia, "Markov random field image segmentation using cellular neural network," IEEE Transactions on Circuits And Systems II, vol. 44, pp. 86 $89,1997$.

[11] A. Blake and A. Zisserman, Visual Reconstruction. Cambridge, MA, U.S.A.: MIT Press, 1987. 
[12] V. Caselles, R. Kimmel, and G. Sapiro, "Geodesic active contours," in Computer Vision, 1995. Proceedings., Fifth International Conference on. IEEE, 1995, pp. 694-699.

[13] L. Cohen, "On active contours and balloons," CVGIP: Image Understanding, vol. 53, pp. 211-218, 1991.

[14] M. Kass, A. Witkin, and D. Terzopoulos, "Snakes: Active contour models," International Journal of Computer Vision, vol. 1, no. 4, pp. 321-331, 1988.

[15] D. Mumford and J. Shah, "Optimal approximation by piecewise smooth functions and associated variational problems," Communications on Pure and Applied Mathematics, vol. 42, pp. 577-684, 1989.

[16] R. O. Duda and P. E. Hart, "Use of the hough transformation to detect lines and curves in pictures," Communications of the ACM, vol. 15, no. 1, pp. 11-15, 1972.

[17] J. Illingworth and J. Kittler, "The adaptive hough transform," IEEE Transactions on Pattern Analysis and Machine Intelligence, no. 5, pp. 690-698, 1987.

[18] C. Benedek, "An embedded marked point process framework for three-level object population analysis," IEEE Transactions on Image Processing, vol. 26, no. 9, pp. 4430-4445, 2017.

[19] G. Perrin, X. Descombes, and J. Zerubia, "A marked point process model for tree crown extraction in plantations," in Image Processing, 2005. ICIP 2005. IEEE International Conference on, vol. 1. IEEE, 2005, pp. I-661.

[20] P. Thevenaz and M. Unser, "Snakuscules," IEEE Transactions on image processing, vol. 17, no. 4, pp. 585-593, 2008.

[21] P. Thevenaz, R. Delgado-Gonzalo, and M. Unser, "The ovuscule," IEEE transactions on pattern analysis and machine intelligence, vol. 33, no. 2, pp. 382-393, 2011.

[22] D. Mumford and J. Shah, "Boundary detection by minimizing functionals," in Proc. IEEE Computer Vision and Pattern Recognition (CVPR), 1985, pp. 22-26.

[23] L. A. Vese and T. F. Chan, "A multiphase level set framework for image segmentation using the mumford and shah model," International Journal of Computer Vision, pp. $271-293,2002$.

[24] G. Aubert and P. Kornprobst, Mathematical Problems in Image Processing. New York, NY, USA: Springer-Verlag, 2002.

[25] L. Ambrosio and V. M. Tortorelli, "Approximation of functional depending on jumps by elliptic functional via t-convergence," Communications on Pure and Applied Mathematics, vol. 43, pp. 999-1036, 1990. 
[26] A. Chambolle, "Image segmentation by variational methods: Mumford and Shah functional and the discrete approximations," SIAM Journal of Applied Mathematics, vol. 55, no. 3, pp. 827-863, 1995.

[27] T. Chan and L. Vese, "An active contour model without edges," in International Conference on Scale-Space Theories in Computer Vision. Springer, 1999, pp. $141-151$.

[28] V. Caselles, F. Catte, T. Coll, and F. Dibos, "A geometric model for active contours," Numerische Mathematik, vol. 66, pp. 1-31, 1993.

[29] V. Caselles, R. Kimmel, G. Sapiro, and C. Sbert, "A three dimensional segmentation approach," IEEE Transactions on Pattern Analysis and Machine Intelligence, vol. 19, no. 4, pp. $394-398,1997$.

[30] S. Kichenassamy, A. Kumar, P. Olver, A. Tannenbaum, and A. Yezzi, "Gradient flows and geometric active contour models," in Proc. IEEE International Conference on Computer Vision (ICCV), Boston, MA, USA, 1995, pp. 810-815.

[31] G. Storvik, "A bayesian approach to dynamic contours through stochastic sampling and simulated annealing," IEEE Transactions on Pattern Analysis and Machine Intelligence, vol. 16, no. 10, pp. 976-986, 1994.

[32] M. Kulikova, I. Jermyn, X. Descombes, J. Zerubia, and E. Zhizhina, "A marked point process model with strong prior shape information for the extraction of multiple, arbitrarily-shaped objects," in Signal-Image Technology 8 Internet-Based Systems (SITIS), 2009 Fifth International Conference on. IEEE, 2009, pp. 180186.

[33] S. Osher and R. P. Fedkiw, Level set methods and dynamic implicit surfaces, ser. Applied mathematical science. New York, NY, USA: Springer, 2003.

[34] S. Osher and N. Paragios, Geometric Level Set Methods in Imaging, Vision, and Graphics. New York: Springer, 2003.

[35] J. A. Sethian, Level Set Methods and Fast Marching Methods: Evolving Interfaces in Geometry Fluid Mechanics, Computer Vision and Materials Science. Cambridge, England: Cambridge University Press, 1999.

[36] R. Malladi, J. A. Sethian, and B. C. Vemuri, "Shape modeling with front propagation: A level set approach," IEEE Transactions on Pattern Analysis and Machine Intelligence, vol. 17, pp. 158-175, 1995.

[37] W. J. Boettinger, J. A. Warren, C. Beckermann, and A. Karma, "Phase-field simulation of solidification," Annual review of materials research, vol. 32, no. 1, pp. 163-194, 2002. 
[38] M. Rochery, I. H. Jermyn, and J. Zerubia, "Higher order active contours," International Journal of Computer Vision, vol. 69, no. 1, pp. 27-42, 2006.

[39] P. Horvath, I. H. Jermyn, Z. Kato, and J. Zerubia, "A higher-order active contour model of a 'gas of circles' and its application to tree crown extraction," Pattern Recognition, vol. 42, no. 5, pp. 699-709, 2009.

[40] M. Rochery, I. H. Jermyn, and J. Zerubia, "Phase field models and higher-order active contours," pp. 970-976, 2005.

[41] P. Horváth and I. H. Jermyn, "A 'gas of circles' phase field model and its application to tree crown extraction," in Proc. European Signal Processing Conference (EUSIPCO), 2007.

[42] Y. He, H. Gong, B. Xiong, X. Xu, A. Li, T. Jiang et al., "icut: an integrative cut algorithm enables accurate segmentation of touching cells," Scientific Reports, vol. 5, p. $12089,2015$.

[43] W. Kenong, D. Gauthier, and M. Levine, "Live cell image segmentation," IEEE Transactions on Biomedical Engineering, vol. 42, no. 1, pp. 1-12, 1995.

[44] Y. Boykov and V. Kolmogorov, "Computing geodesics and minimal surfaces via graph cuts." in ICCV. IEEE, 2003, pp. 26-33.

[45] J. Shi and J. Malik, "Normalized cuts and image segmentation," IEEE Transactions on Pattern Analysis and Machine Intelligence, vol. 22, no. 8, pp. 888-905, 2000.

[46] V. Caselles, R. Kimmel, and G. Sapiro, "Geodesic active contours," International Journal of Computer Vision, vol. 22, no. 1, pp. 61-79, 1997.

[47] T. Chan and L. Vese, "A multiphase level set framework for image segmentation using the Mumford and Shah model," International Journal of Computer Vision, vol. 50, no. 3, pp. $271-293,2002$.

[48] O. Daněk, P. Matula, C. Ortiz-de Solórzano, A. Muñoz-Barrutia, M. Maška, and M. Kozubek, "Segmentation of touching cell nuclei using a two-stage graph cut model," in Scandinavian Conference on Image Analysis. Springer, 2009, pp. 410419.

[49] C. Sommer, C. Straehle, U. Koethe, and F. A. Hamprecht, "Tlastik: Interactive learning and segmentation toolkit," in Biomedical Imaging: From Nano to Macro, 2011 IEEE International Symposium on. IEEE, 2011, pp. 230-233.

[50] S. Beucher and F. Meyer, "The morphological approach to segmentation: the watershed transformation," Optical Engineering-New York-Marcel Dekker Incorporated-, vol. 34, pp. 433-433, 1992. 
[51] H. Chang, Q. Yang, and B. Parvin, "Segmentation of heterogeneous blob objects through voting and level set formulation," Pattern Recognition Letters, vol. 28, no. 13 , pp. 1781-1787, 2007.

[52] G. Li, T. Liu, J. Nie, L. Guo, J. Chen, J. Zhu et al., "Segmentation of touching cell nuclei using gradient flow tracking," Journal of Microscopy, vol. 231, no. 1, pp. $47-58,2008$.

[53] A. Pinidiyaarachchi and C. Wählby, "Seeded watersheds for combined segmentation and tracking of cells." in ICIAP. Springer, 2005, pp. 336-343.

[54] X. Qi, F. Xing, D. J. Foran, and L. Yang, "Robust segmentation of overlapping cells in histopathology specimens using parallel seed detection and repulsive level set," IEEE Transactions on Biomedical Engineering, vol. 59, no. 3, pp. 754-765, 2012 .

[55] Q. Yang and B. Parvin, "Harmonic cut and regularized centroid transform for localization of subcellular structures," IEEE Transactions on Biomedical Engineering, vol. 50, no. 4, pp. $469-475,2003$.

[56] B. Parvin, Q. Yang, J. Han, H. Chang, B. Rydberg, and M. H. Barcellos-Hoff, "Iterative voting for inference of structural saliency and characterization of subcellular events," IEEE Transactions on Image Processing, vol. 16, no. 3, pp. 615-623, 2007.

[57] T. Jiang and F. Yang, "An evolutionary tabu search for cell image segmentation," Systems, Man, and Cybernetics, Part B: Cybernetics, IEEE Transactions on, vol. 32 , no. 5, pp. $675-678,2002$.

[58] S. Kothari, Q. Chaudry, and M. D. Wang, "Automated cell counting and cluster segmentation using concavity detection and ellipse fitting techniques," in Biomedical Imaging: From Nano to Macro, 2009. ISBI'09. IEEE International Symposium on. IEEE, 2009, pp. 795-798.

[59] J.-C. Olivo-Marin, "Extraction of spots in biological images using multiscale products," Pattern recognition, vol. 35, no. 9, pp. 1989-1996, 2002.

[60] Z. Püspöki, D. Sage, J. P. Ward, and M. Unser, "Spotcaliper: fast wavelet-based spot detection with accurate size estimation," Bioinformatics, vol. 32, no. 8, pp. 1278-1280, 2015.

[61] T. Jones, A. Carpenter, and P. Golland, "Voronoi-based segmentation of cells on image manifolds," in Computer Vision for Biomedical Image Applications. Springer, 2005, pp. 535-543.

[62] S. Wienert, D. Heim, K. Saeger, A. Stenzinger, M. Beil, P. Hufnagl et al., "Detection and segmentation of cell nuclei in virtual microscopy images: A minimummodel approach," Scientific Reports, vol. 2, p. 503, 2012. 
[63] G. Fernandez, M. Kunt, and J.-P. Zrÿd, "A new plant cell image segmentation algorithm," in International Conference on Image Analysis and Processing. Springer, 1995, pp. 229-234.

[64] T. Stoeger, N. Battich, M. D. Herrmann, Y. Yakimovich, and L. Pelkmans, "Computer vision for image-based transcriptomics," Methods, vol. 85, pp. 44-53, 2015.

[65] S. Kumar, S. H. Ong, S. Ranganath, T. C. Ong, and F. T. Chew, "A rule-based approach for robust clump splitting," Pattern Recognition, vol. 39, no. 6, pp. 10881098, 2006.

[66] M. Rochery, I. H. Jermyn, and J. Zerubia, "New higher-order active contour energies for network extraction," in Proc. IEEE International Conference on Image Processing (ICIP), 2005.

[67] M. Rochery, I. H. Jermyn, and J. Zerubia, "Gap closure in (road) networks using higher-order active contours," in Proc. IEEE International Conference on Image Processing (ICIP), 2004.

[68] M. Rochery, I. H. Jermyn, and J. Zerubia, "Higher order active contours," International journal of computer vision, vol. 69, no. 1, pp. 27-42, 2006.

[69] C. Molnar, Z. Kato, and I. Jermyn, "A multi-layer phase field model for extracting multiple near-circular objects," in Pattern Recognition (ICPR), 2012 21st International Conference on. IEEE, 2012, pp. 1427-1430.

[70] N. Anastasov, I. Höfig, V. Radulović, S. Ströbel, M. Salomon, J. Lichtenberg et al., "A 3d-microtissue-based phenotypic screening of radiation resistant tumor cells with synchronized chemotherapeutic treatment," BMC cancer, vol. 15, no. 1, p. $466,2015$.

[71] J. A. Hickman, R. Graeser, R. de Hoogt, S. Vidic, C. Brito, M. Gutekunst et al., "Three-dimensional models of cancer for pharmacology and cancer cell biology: Capturing tumor complexity in vitro/ex vivo," Biotechnology journal, vol. 9, no. 9, pp. 1115-1128, 2014.

[72] M. Nobis, E. J. McGhee, J. P. Morton, J. P. Schwarz, S. A. Karim, J. Quinn et al., "Intravital flim-fret imaging reveals dasatinib-induced spatial control of src in pancreatic cancer," Cancer research, vol. 73, no. 15, pp. 4674-86, 2013.

[73] K. Smith, Y. Li, F. Piccinini, G. Csucs, C. Balazs, A. Bevilacqua et al., "Cidre: an illumination-correction method for optical microscopy," Nature methods, vol. 12, no. 5, pp. 404-406, 2015.

[74] C. Molnar, Z. Kato, and I. H. Jermyn, "A new model for the segmentation of multiple, overlapping, near-circular objects," in Digital Image Computing: Techniques and Applications (DICTA), 2015 International Conference on. IEEE, 2015, pp. $1-5$. 
[75] C. Molnar, I. H. Jermyn, Z. Kato, V. Rahkama, P. Östling, P. Mikkonen et al., "Accurate morphology preserving segmentation of overlapping cells based on active contours," Scientific reports, vol. 6, p. 32412, 2016.

[76] B. Neumann, T. Walter, J.-K. HĂ ̌́rich ĂS̆, J. Bulkescher, H. Erfle, C. Conrad et al., "Phenotypic profiling of the human genome by time-lapse microscopy reveals cell division genes," Nature, vol. 464, no. 7289, pp. 721-727, 2010.

[77] P. Horváth, I. Jermyn, J. Zerubia, and Z. Kato, "A higher-order active contour model for tree detection," in Pattern Recognition, 2006. ICPR 2006. 18th International Conference on, vol. 2. IEEE, 2006, pp. 130-133.

[78] A. Lehmussola, P. Ruusuvuori, J. Selinummi, H. Huttunen, and O. Yli-Harja, "Computational framework for simulating fluorescence microscope images with cell populations," IEEE transactions on medical imaging, vol. 26, no. 7, pp. 1010-1016, 2007.

[79] M. Kass, A. Witkin, and D. Terzopoulos, "Snakes - active contour models," International journal of computer vision, vol. 1, no. 4, pp. 321-331, 1987.

[80] S. Lankton and A. Tannenbaum, "Localizing region-based active contours," IEEE Transactions on Image Processing, vol. 17, no. 10, pp. 2029-2039, 2008.

[81] C. Li, C.-Y. Kao, J. C. Gore, and Z. Ding, "Minimization of Region-Scalable Fitting Energy for Image Segmentation," Image Processing, IEEE Transactions on, vol. 17, no. 10, pp. 1940-1949, 2008.

[82] D. Zhang and G. Lu, "Review of shape representation and description techniques," Pattern Recognition, vol. 37, pp. 1-19, 2004.

[83] D. Mumford, "Elastica and computer vision," in Algebraic geometry and its applications. New York, NY, USA: Springer, 1994, pp. 491-506.

[84] O. Faugeras and R. Keriven, "Variational principles, surface evolution, pdes, level set methods, and the stereo problem," IEEE Transactions on Image Processing, vol. 7 , no. 3, pp. 336-344, 1998.

[85] J. Molnár, D. Chetverikov, D. C. DeBuc, W. Gao, and G. M. Somfai, "Layer extraction in rodent retinal images acquired by optical coherence tomography," Machine Vision and Applications, vol. 23, no. 6, pp. 1129-1139, 2012.

[86] R. Kimmel and A. M. Bruckstein, "Regularized laplacian zero crossings as optimal edge integrators." International Journal of Computer Vision, vol. 53, no. 3, pp. $225-243,2003$.

[87] J. Molnar, C. Molnar, and P. Horvath, "An object splitting model using higherorder active contours for single-cell segmentation," in International Symposium on Visual Computing. Springer, 2016, pp. 24-34. 
[88] J. Molnar, A. I. Szucs, C. Molnar, and P. Horvath, "Active contours for selective object segmentation," in Applications of Computer Vision (WACV), 2016 IEEE Winter Conference on. IEEE, 2016, pp. 1-9.

[89] A. E. Carpenter, T. R. Jones, M. R. Lamprecht, C. Clarke, I. H. Kang, O. Friman et al., "Cellprofiler: image analysis software for identifying and quantifying cell phenotypes," Genome biology, vol. 7, no. 10, p. R100, 2006.

[90] J. C. Clemens, C. A. Worby, N. Simonson-Leff, M. Muda, T. Maehama, B. A. Hemmings et al., "Use of double-stranded rna interference in drosophila cell lines to dissect signal transduction pathways," Proceedings of the National Academy of Sciences, vol. 97, no. 12, pp. 6499 6503, 2000.

[91] C. J. Echeverri and N. Perrimon, "High-throughput rnai screening in cultured cells: a user's guide," Nature Reviews Genetics, vol. 7, no. 5, p. 373, 2006.

[92] U. S. Eggert, A. A. Kiger, C. Richter, Z. E. Perlman, N. Perrimon, T. J. Mitchison et al., "Parallel chemical genetic and genome-wide rnai screens identify cytokinesis inhibitors and targets," PLoS biology, vol. 2, no. 12, p. e379, 2004.

[93] L. Wilets, "Shape of the nucleus: It varies widely, from spherical for doubly magic nuclei to ellipsoidal and sometimes pear shapes," Science, vol. 129, no. 3346, pp. 361-367, 1959.

[94] Z. Farkas, D. Kalapis, Z. Bódi, B. Szamecz, A. Daraba, K. Almási et al.. "Hsp70associated chaperones have a critical role in buffering protein production costs," eLife, vol. 7, p. e29845, 2018.

[95] F. Piccinini, T. Balassa, A. Szkalisity, C. Molnar, L. Paavolainen, K. Kujala et al., "Advanced cell classifier: user-friendly machine-learning-based software for discovering phenotypes in high-content imaging data," Cell systems, vol. 4, no. 6, pp. $651-655,2017$.

[96] C. Brasko, K. Smith, C. Molnar, N. Farago, L. Hegedus, A. Balind et al., "Intelligent image-based in situ single-cell isolation," Nature communications, vol. 9, no. 1, p. 226, 2018. 